RAFAEL FERNANDES DE MATOS

Diretrizes para formulação de estratégia de desenvolvimento de empresas de execução especializada de serviços de obra com foco na inovação 
RAFAEL FERNANDES DE MATOS

Diretrizes para formulação de estratégia de desenvolvimento de empresas de execução especializada de serviços de obra com foco na inovação

Dissertação apresentada à Escola Politécnica da Universidade de São Paulo para obtenção do título de Mestre em Ciências

Orientador: Prof. Dr. Francisco Ferreira Cardoso 


\section{RAFAEL FERNANDES DE MATOS}

Diretrizes para formulação de estratégia de desenvolvimento de empresas de execução especializada de serviços de obra com foco na inovação

Dissertação apresentada à Escola Politécnica da Universidade de São Paulo para obtenção do título de Mestre em Ciências

Área de Concentração: Inovação na Construção Civil

Orientador: Prof. Dr. Francisco Ferreira Cardoso 
Este exemplar foi revisado e corrigido em relação à versão original, sob responsabilidade única do autor e com a anuência de seu orientador.

São Paulo, de de

Assinatura do autor:

Assinatura do orientador:

Catalogação-na-publicação

Matos, Rafael

Diretrizes para formulação de estratégia de desenvolvimento de empresas de execução especializada de serviços de obra com foco na inovação / R. Matos -- versão corr. - São Paulo, 2017.

$123 \mathrm{p}$.

Dissertação (Mestrado) - Escola Politécnica da Universidade de São Paulo. Departamento de Engenharia de Construção Civil.

1.Construção Civil 2.Inovação 3.Estratégia I.Universidade de São Paulo. Escola Politécnica. Departamento de Engenharia de Construção Civil Il.t. 


\section{RESUMO}

Há muito tem se falado da necessidade de inovação na construção civil. Em geral, a literatura aborda tal tema sob a ótica das empresas construtoras, discutindo formas de implantação de novas tecnologias a seu processo construtivo. Pesquisas sobre inovação em empresas de execução especializada de serviços de obras (EEE), no entanto, são mais raras. Tais empresas são de porte médio ou grande, formalmente constituídas e que possuem domínio técnico completo de suas atividades de produção. Este trabalho, desenvolvido no âmbito de um mestrado profissional, teve como objetivo principal identificar um processo de planejamento estratégico para definir diretrizes para formulação de uma estratégia com foco na inovação em uma EEE de alvenaria sediada em São Paulo. Por meio de pesquisa relacionadas à temas como administração, estratégia e inovação e da experiência profissional, identificou-se um processo prático e visual por meio da construção e comparação de cenários utilizando o Quadro de Modelo de Negócio (Business Model Canvas). Tal processo foi utilizado na prática para estabelecer as diretrizes para três estratégias de inovação distintas de uma EEE de alvenaria. Como objetivo secundário, o trabalho reuniu, por meio de pesquisa, características que empresas consideradas inovadoras devem apresentar como visão de longo prazo, capacidade de identificar oportunidades, a existência de capacidade inovativa, a formulação de uma estratégia de inovação, boa administração, a disposição da liderança para correr riscos, uma estrutura organizacional ambidestra, a disponibilidade de se fazer investimentos e uma cultura organizacional que não seja avessa ao erro.

Palavras-Chave: Construção Civil. Inovação. Estratégia. 


\begin{abstract}
There has long been talk of the need for innovation in construction. In general, the literature approaches this theme from the point of view of construction companies, discussing ways to implement new technologies in their construction process. Research on innovation in specialized execution of works (EEE) firms, however, is rarer. Such companies are of medium or large size, formally constituted and that have full technical control of their production activities. The main objective of this work, developed within a professional master's degree, was to identify a strategic planning process to define guidelines for the formulation of a strategy focused on innovation in a masonry EEE based in São Paulo. Through research related to topics such as administration, strategy and innovation and professional experience, a practical and visual process was identified through the construction and comparison of scenarios using the Business Model Canvas. This process was used in practice to establish guidelines for three distinct innovation strategies for a masonry EEE. As a secondary objective, the work brought together, by means of research, characteristics that companies considered innovative should present as long-term vision, capacity to identify opportunities, the existence of innovative capacity, the formulation of an innovation strategy, good management, risk leadership, an ambitious organizational structure, the availability of investment, and an organizational culture that is not error-prone.
\end{abstract}

Keywords: Civil Engineering. Innovation. Strategy. 


\section{LISTA DE ILUSTRAÇÕES}

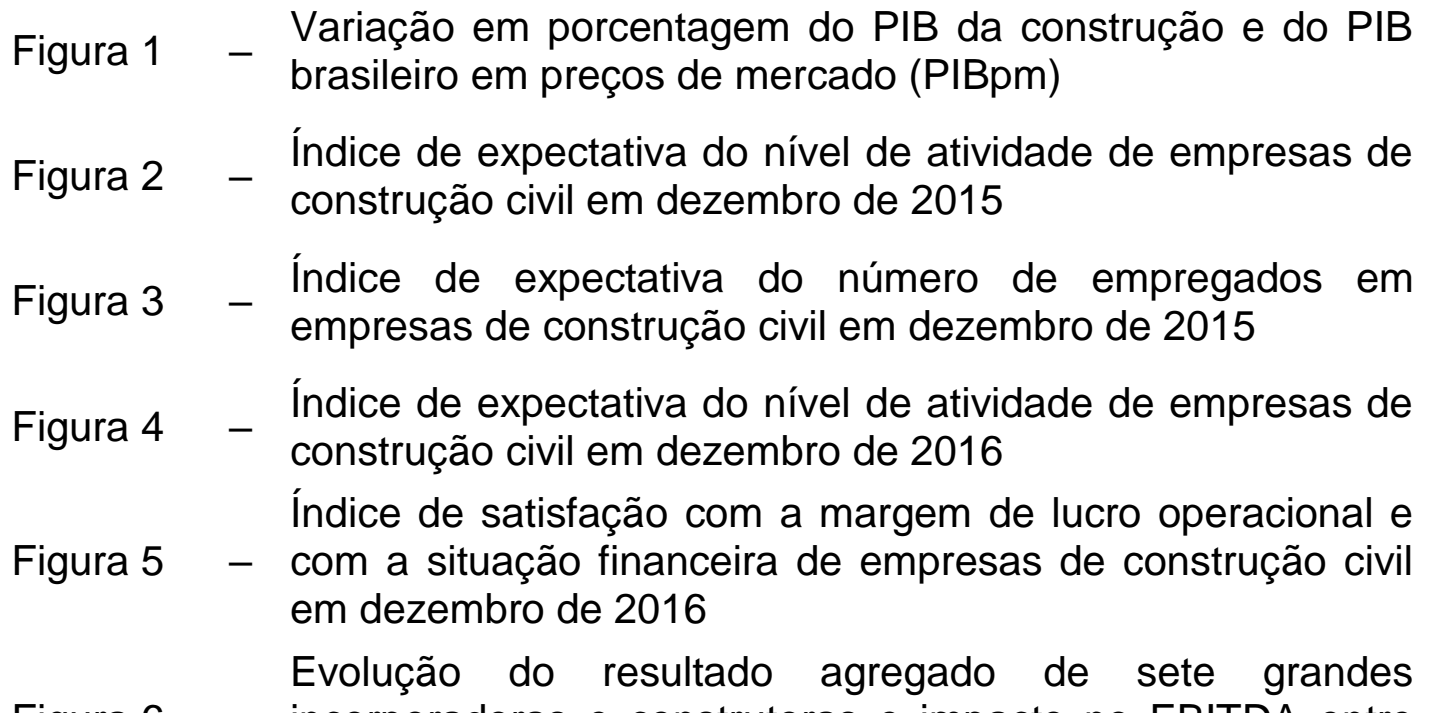

Figura 6 - incorporadoras e construtoras e impacto no EBITDA entre 10 20072011

Figura 7 - Estrutura de composição da cadeia produtiva do setor de edificações da indústria da construção civil

Produtividade dos fatores de produção (trabalhador e capital)

Figura 8 - e produtividade total dos fatores por segmento de atividade 12 (\% ao ano)

Figura 9 - Bases do planejamento estratégico para a teoria neoclássica 26

Figura 10 - As cinco forças de Porter 29

Figura 11 - Valor, preço e margem 31

Figura 12 - As ondas de transformação de Schumpeter 35

Figura 13 - Etapas estratégicas e táticas do processo de planejamento 38

O processo de planejamento estratégico utilizando o conceito

Figura 14 - de modelo de negócio proposto por Casadesus-Masanell e 38 Ricart

Figura 15 - O Quadro de Modelo de Negócio (Business Model Canvas) 39

$\begin{array}{lll}\text { Figura } 16 & \begin{array}{l}\text { Alterações e evolução do modelo de negócio utilizando o } \\ \text { Quadro de Modelo de Negócio }\end{array} & 41\end{array}$

Figura 17 - $\begin{aligned} & \text { Níveis hierárquicos estratificados segundo a teoria } \\ & \text { neoclássica da administração }\end{aligned}$ Diferenças de tarefas administrativas, contexto,

Figura 18 - comportamento, preocupação básica e lógica de cada 43 subsistema organizacional 
Diferenças de visão predominante, perspectiva, ponto de

Figura 19 - vista, processos gerais e características da tomada de decisão de cada subsistema organizacional Figura 20 - As funções administrativas organizadas em sequência,

Figura 21 - Diferença nas formas de planejamento, organização, direção e controle de cada subsistema organizacional

Figura 22 Os desdobramentos dos objetivos das empresas

Figura 23 - $\begin{aligned} & \text { Propriedade das estruturas organizacionais mecanicistas e } \\ & \text { orgânicas }\end{aligned}$

Figura 24 - A relação entre estratégia, estratégia de inovação e estratégia tecnológica Figura 25 - $\begin{aligned} & \text { Retorno sobre investimento a partir de inovações nos três } \\ & \text { horizontes }\end{aligned}$

Figura 26 - Campo das políticas de inovação

Figura 27 - Capacidade inovativa das empresas

Figura 28 - Modelo das 10 dimensões de gestão da inovação 75

Figura 29 - Estrutura organizacional ambidestra 76

Figura 30 - Composição e participação das EES no setor de edificações da indústria da construção civil

Figura 31 - $\begin{aligned} & \text { Linhas de vanguarda e retaguarda e suas funções na } \\ & \text { estrutura organizacional das EES }\end{aligned}$

Figura 32 - Estrutura organizacional das EES em termos das funções exercidas por seus profissionais

Figura 33 - Macroprocessos e sua relação com as linhas de vanguarda e retaguarda na estrutura organizacional das EES

Figura 34 - Linhas de vanguarda e retaguarda na estrutura

Figura 35 - Quadro de Modelo de Negócio vigente de EEE de alvenaria de vedação de edifícios multipavimento

Quadro de Modelo de Negócio planejado para o ingresso da

Figura 36 - EEE de alvenaria num mercado adjacente: o de construção 99 seriada de habitações de interesse social

Quadro de Modelo de Negócio planejado para o ingresso da

Figura 37 - EEE de alvenaria num mercado completamente novo: o de 103 fabricação de equipamentos metálicos 


\section{LISTA DE QUADROS}

\begin{tabular}{|c|c|c|}
\hline Quadro 1 & - & $\begin{array}{l}\text { Componentes do Quadro de Modelo de Negócio (Business } \\
\text { Model Canvas) }\end{array}$ \\
\hline Quadro 2 & - & Características dos sistemas mecânicos e orgânicos \\
\hline Quadro 3 & - & Vantagens que podem ser obtidas por meio da inovação \\
\hline Quadro 4 & - & $\begin{array}{l}\text { Vantagens e desvantagens da inovação em empresas de } \\
\text { menor porte }\end{array}$ \\
\hline Quadro 5 & - & Como o ambiente afeta a forma de inovar das empresas \\
\hline Quadro 6 & - & Diferenças entre princípios da inovação fechada e aberta \\
\hline Quadro 7 & - & $\begin{array}{l}\text { Gatilhos para a inovação radical e os impactos sobre as } \\
\text { empresas que se deparam com eles }\end{array}$ \\
\hline Quadro 8 & - & $\begin{array}{l}\text { Incompatibilidades fundamentais no modelo de negócio } \\
\text { vidente de uma empresa }\end{array}$ \\
\hline Quadro 9 & - & Características de uma estrutura organizacional ambidestra \\
\hline Quadro 10 & - & Diferenças entre SE e as EEE e ESC \\
\hline Qua & - & ão dos macroprocessos que compõem uma EES \\
\hline
\end{tabular}




\section{LISTA DE ABREVIATURA E SIGLAS}

$\begin{array}{ll}\text { CBIC } & \text { Câmara Brasileira da Indústria da Construção } \\ \text { CNI } & \text { Confederação Nacional da Indústria } \\ \text { EBITDA } & \text { Earnings Before Interest, Taxes, Depreciation and Amortization } \\ \text { ECS } & \text { Escopo Comercializado para a Prestação de Serviço } \\ \text { EEE } & \text { Empresas de Execução Especializada de Serviços de Obras } \\ \text { EES } & \text { Empresas de Execução de Serviços de Obras } \\ \text { ESC } & \text { Empresas Executoras de Serviços Complexos de Obras } \\ \text { FINEP } & \text { Financiadora de Estudos e Projetos } \\ \text { FGV } & \text { Fundação Getúlio Vargas } \\ \text { IBGE } & \text { Instituto Brasileiro de Geografia e Estatística } \\ \text { MCT } & \text { Ministério da Ciência e Tecnologia } \\ \text { OCDE } & \text { Organização para a Cooperação e Desenvolvimento Econômico } \\ \text { PIB } & \text { Produto Interno Bruto } \\ \text { PTF } & \text { Produtividade Total do Fatores } \\ \text { P\&D } & \text { Pesquisa e Desenvolvimento } \\ \text { SE } & \text { Empresas de Execução de Serviços de Obras Subempreitadas }\end{array}$




\section{SUMÁRIO}

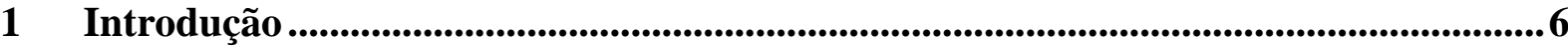

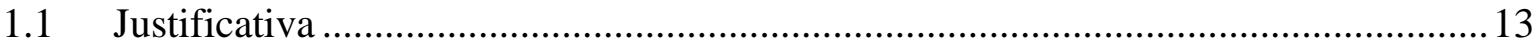

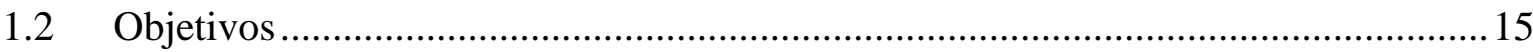

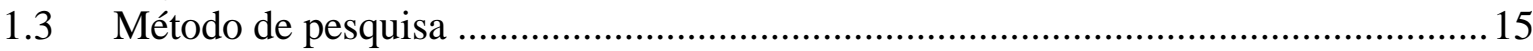

1.3.1 Considerações sobre o método no capitulo "Administração, estratégia e organização de empresas".................................................................................... 15

1.3.2 Considerações sobre o método no capítulo "A prática da inovação nas empresas".

1.3.3 Considerações sobre o método no capitulo "Estratégia e inovação em uma empresa de execução especializada de serviços de obras de alvenaria" ...........................17

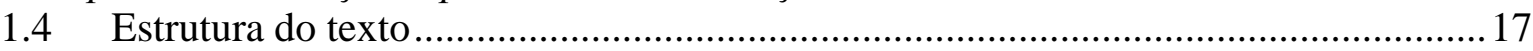

2 Considerações sobre administração, estratégia e organização de empresas...............18

$2.1 \quad$ As diversas faces da estratégia............................................................................ 19

2.2 Fundamentos do processo de planejamento estratégico …………............................21

2.2.1 O processo de planejamento estratégico para a teoria neoclássica da

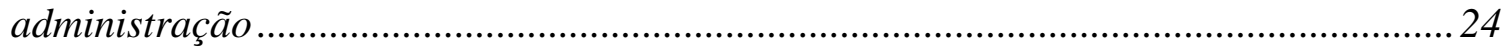

2.2.2 O processo de planejamento estratégico para a teoria da contingência da

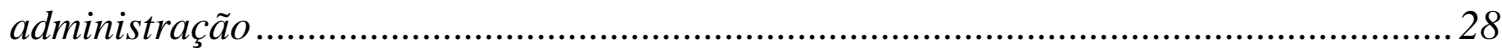

2.2.3 O processo de planejamento estratégico em mercados imprevisíveis, modeláveis e competitivos utilizando o Quadro de Modelo de Negócio (Business Model Canvas)...34

2.3 Características básicas da estrutura organizacional de uma empresa ..........................42

2.3.1 Influência da estratégia na estrutura organizacional das empresas ...................46

3 A prática da inovação nas empresas ...........................................................................48

3.1 As diversas faces da inovação.......................................................................52

3.1.1 Inovação tecnológica e não tecnológica …………………………………….......5

3.1.2 Inovação quanto ao objeto focal da inovação....................................................55

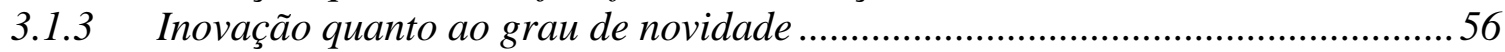

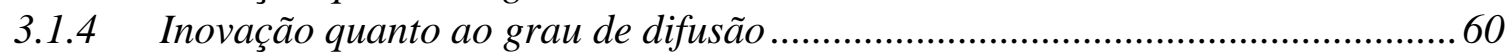

3.2 A estratégia de inovação ......................................................................................61

3.2.1 Processo de planejamento estratégico da inovação utilizando os conceitos de

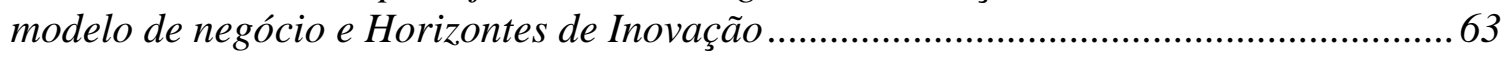

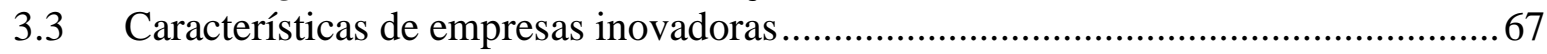

3.3.1 A influência da inovação na estrutura organizacional das empresas ................ 75

4 Estratégia e inovação em uma empresa de execução especializada de serviços de obra de alvenaria ...............................................................................................................................78

4.1 Estrutura de uma empresa de execução especializada de serviços de obras............... 84

4.2 Natureza da inovação em empresas de execução especializada de serviços deobras 90

4.3 Definição de diretrizes por meio da aplicação do processo de planejamento estratégico da inovação utilizando os conceitos de Quadro de Modelo de Negócio e de Horizontes de

Inovação em uma EEE inovadora de alvenaria .....................................................................94

4.3.1 Definição de diretrizes para inovações no Horizonte 1 1...................................... 96

4.3.2 Definição de diretrizes para inovações no Horizonte 2 2........................................99

4.3.3 Definição de diretrizes para inovações no Horizonte 3.....................................101

5 Considerações finais ..............................................................................................................104

6 Referências ................................................................................................................................. 108 


\section{Introdução}

A construção civil é um dos principais setores da economia brasileira. Segundo dados do IBGE, entre outubro e dezembro de 2015, o setor empregou 7,9 milhões de pessoas, sendo responsável por 6,2\% do PIB brasileiro, que superou a marca de 6 trilhões de reais em 2015. Sozinha, a indústria da construção civil foi responsável por 5,9\% do valor adicionado bruto a preços básicos (VABpb) de todo o país e por quase um terço $(26,4 \%)$ do VABpb de toda a indústria nacional daquele ano.

No entanto, a análise desses números de forma absoluta esconde uma conjuntura econômica bastante adversa. Desde 2014, a construção civil atravessa um período de forte crise econômica, apresentando uma taxa real de crescimento negativa. Nos anos de 2014, 2015 e 2016, o PIB da construção civil foi de, respectivamente, $-2,1 \%$; -6,5\% e -5,2\% (Figura 1). Em 2017, a tendência é a manutenção deste cenário de retração econômica pelo quarto ano seguido.

O PIB é um dos principais indicadores de atividade econômica e representa a soma em valores monetários de todos os bens e serviços produzidos em uma região ou setor econômico. Dada a relevância na indústria da construção civil na economia brasileira, movimentos de crescimento ou retração desse setor são capazes de gerar impactos econômicos e sociais bastante relevantes na economia do Brasil. Assim, compararmos as variações do PIB construção civil e do PIB brasileiro nos últimos 10 anos, é possível notar a influência que o primeiro tem sobre o segundo (Figura 1).

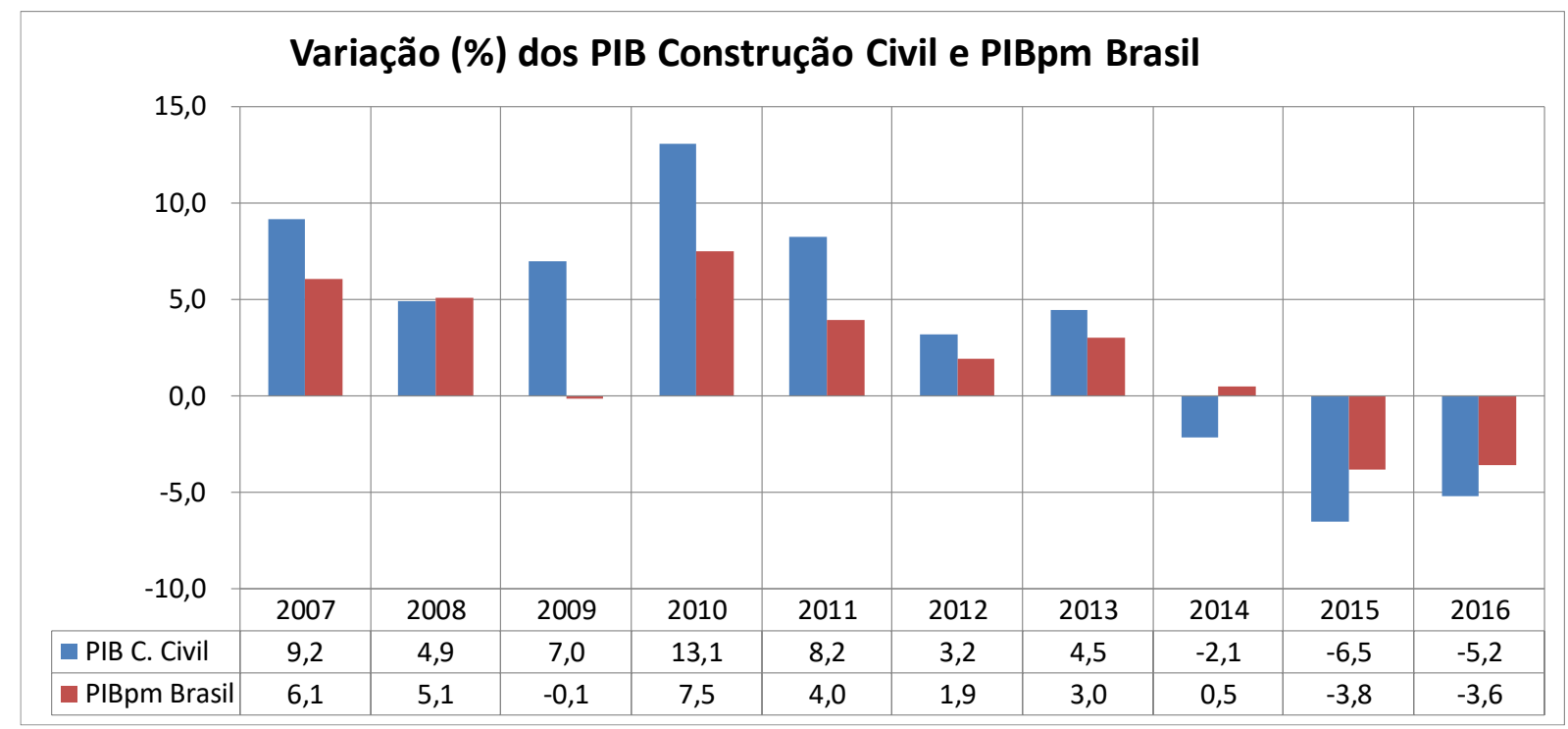

Figura 1 - Variação em porcentagem do PIB da construção civil e do PIB brasileiro em preços de mercado (PIBpm) (fonte: CBIC). 
Outros indicadores de atividade econômica podem ser encontrados em publicações setoriais como a Sondagem Indústria da Construção, publicação mensal da CNI que tem por objetivo identificar situações atuais e antecipar tendências futuras da construção civil brasileira. Nela, dois índices chamam a atenção: o índice da expectativa do nível de atividade e o índice de expectativa do número de empregados. Esses índices variam de 0 a 100 pontos e quando estão acima de 50, indicam uma expectativa de crescimento do nível de atividade e do número de empregados, respectivamente. Por outro lado, quando estão abaixo de 50, a expectativa é de retração.

A edição de dezembro de 2015, por exemplo, encerrou o ano relatando queda intensa e disseminada da atividade e do emprego que, até então, haviam atingido os menores níveis de suas respectivas séries históricas. O índice de expectativa do nível de atividade, que era de 48,6 pontos no começo do ano, foi diminuindo até atingir 37,7 pontos em dezembro (Figura 2). Da mesma forma, o índice de expectativa do número de empregados caiu de 46,9, em janeiro de 2015, para 37,0 pontos em dezembro, denotando pessimismo e uma expectativa crescente de retração econômica (Figura 3). As causas atribuídas a estes resultados foram a elevada carga tributária, a alta taxa de juros e a queda da demanda interna que, aliadas ao aumento do custo dos insumos e à dificuldade de acesso ao crédito, foram aumentando a insatisfação com a situação financeira e com as margens de lucro das empresas ao longo do ano.

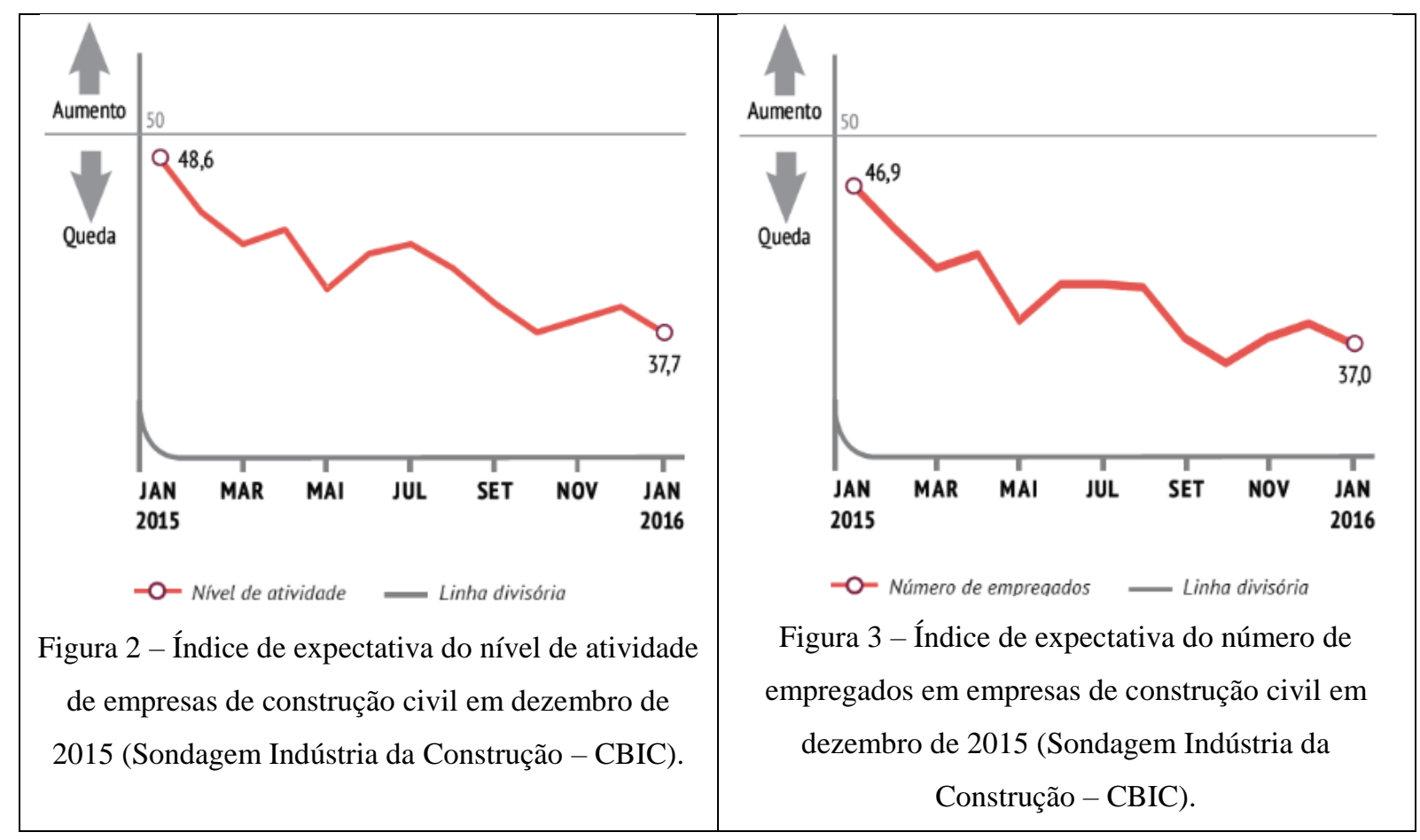


Um ano depois, na edição de dezembro de 2016, os índices de expectativa do nível de atividade e do número de empregados apresentaram melhora, passando de 37,7 para 47,4 pontos e de 37,0 para 45,7 pontos, respectivamente. No entanto, ambos permaneciam abaixo dos 50 pontos, denotando que a expectativa ainda era de retração e que o setor ainda atravessava uma grave crise (Figura 4).

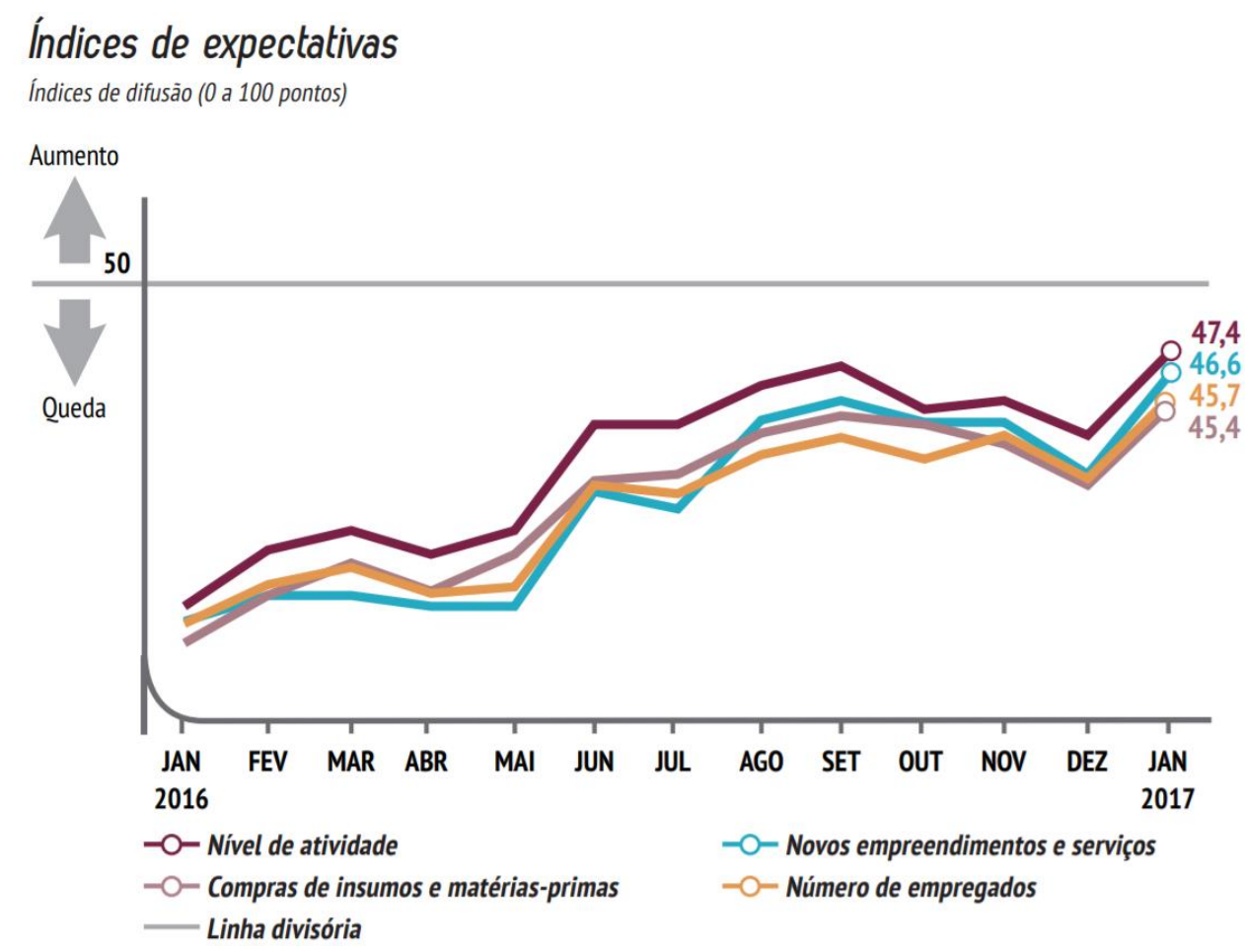

Figura 4 - Índice de expectativa do nível de atividade de empresas de construção civil em dezembro de 2016 (Sondagem Indústria da Construção - CBIC).

Naturalmente, cenários adversos como este impactam as margens de lucro das empresas de construção. De fato, a Sondagem Indústria da Construção quantificou a insatisfação com a situação financeira ao longo dos anos de crise de 2014, 2015 e 2016 por meio de um índice semelhante aos índices de expectativa do nível de atividade e do número de empregados. Os índices de margem de lucro operacional e de satisfação financeira também variam de 0 a 100 pontos, em que valores acima ou abaixo de 50 denotam, respectivamente, satisfação ou insatisfação.

No último trimestre de 2016, o índice de satisfação com a margem de lucro operacional era de, apenas, 31,7 pontos, enquanto o índice de satisfação com a situação financeira da empresa era de 36,0 pontos (Figura 5). 


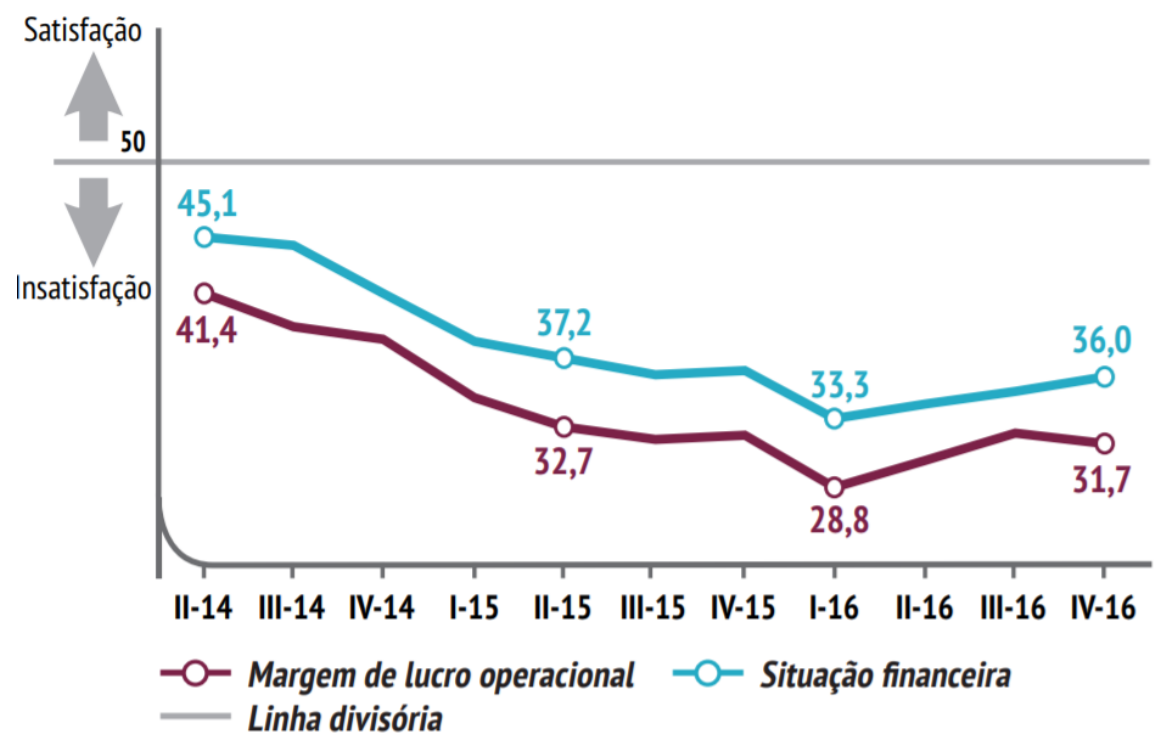

Figura 5 - Índice de satisfação com a margem de lucro operacional e com a situação financeira de empresas de construção civil em dezembro de 2016 (Sondagem Indústria da Construção - CBIC).

No entanto, apesar da queda das margens de lucro ser consequência da atual conjuntura econômica, verificou-se que isto vinha acontecendo antes, durante períodos de crescimento do setor da construção civil.

Entre 2007 e 2012, período em que o PIB nacional aumentava, em média, 3,8\% ao ano e o PIB da construção crescia 80\% mais, um estudo publicado pela consultoria EY (2013), mostrou que, entre 2007 e 2011, os lançamentos das sete maiores incorporadoras e construtoras de capital aberto do País ${ }^{1}$ aumentaram $24 \%\left(\mathrm{em} \mathrm{m}^{2}\right)$ e suas receitas, $50 \%$ ao ano (Figura 6). Com a demanda fomentada por programas do governo federal e com a disponibilidade de crédito para financiamento dos empreendimentos, as empresas vivenciavam um período de euforia econômica bastante diferentes da situação atual.

No entanto, este mesmo estudo mostra que, apesar do período de pujança, as margens de lucro das mesmas sete maiores incorporadoras e construtoras de capital aberto diminuíram, passando de 21\% em 2007 para 16\% em 2011² (Figura 6). Ou seja, apesar do cenário favorável, os custos estavam crescendo a taxas superiores às das receitas, sugerindo queda na produtividade das maiores empresas de construção civil do país.

\footnotetext{
1 Em termos de $\mathrm{m}^{2}$ de área construída - ranking ITC - Inteligência Empresarial da Construção http://www.rankingitc.com.br/.
} 


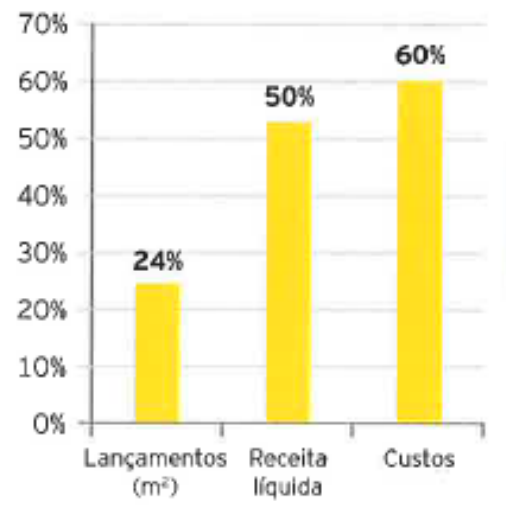

EBITDA

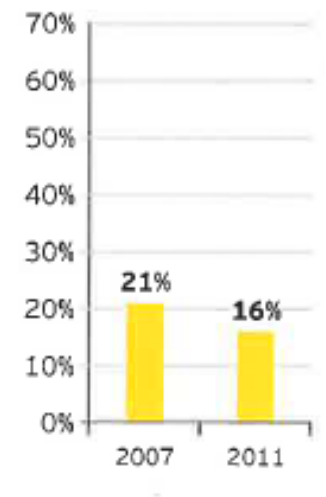

Figura 6 - Evolução do resultado agregado de sete grandes incorporadoras e construtoras e impacto no EBITDA entre 2007 e 2011 (EY, 2013).

De fato, o estudo Produtividade da Construção Civil Brasileira, publicado pela CBIC e pela FGV CBIC (2012), mostra que, entre 2007 e 2012, a produtividade total dos fatores (PTF), indicador que pode ser interpretado como uma medida do progresso tecnológico, aumentou, em média, $0,2 \%$ ao ano nas empresas com 30 ou mais funcionários, que engloba o conjunto formado pelas grandes construtoras.

Ora, não seria então um contrassenso as maiores construtoras do país apresentarem redução uma de suas margens de lucro entre 2007 e 2011, que passaram de 21\% para 16\%, se a produtividade total dos fatores aumentou, em média, $0,2 \%$ ao ano entre 2007 e 2012 ?

Para responder à esta pergunta, é necessário compreender como funciona o processo de produção de um empreendimento e o papel desempenhado pelas empresas construtoras dentro da cadeia produtiva da indústria da construção civil. Cadeia produtiva é um conjunto de atividades desempenhadas por empresas que se articulam progressivamente, fabricando, distribuindo e comercializando desde os insumos básicos até o produto final, isto é, o empreendimento (MCT, 2000). A Figura 7 mostra como a cadeia produtiva do setor de edificações está estruturada. 


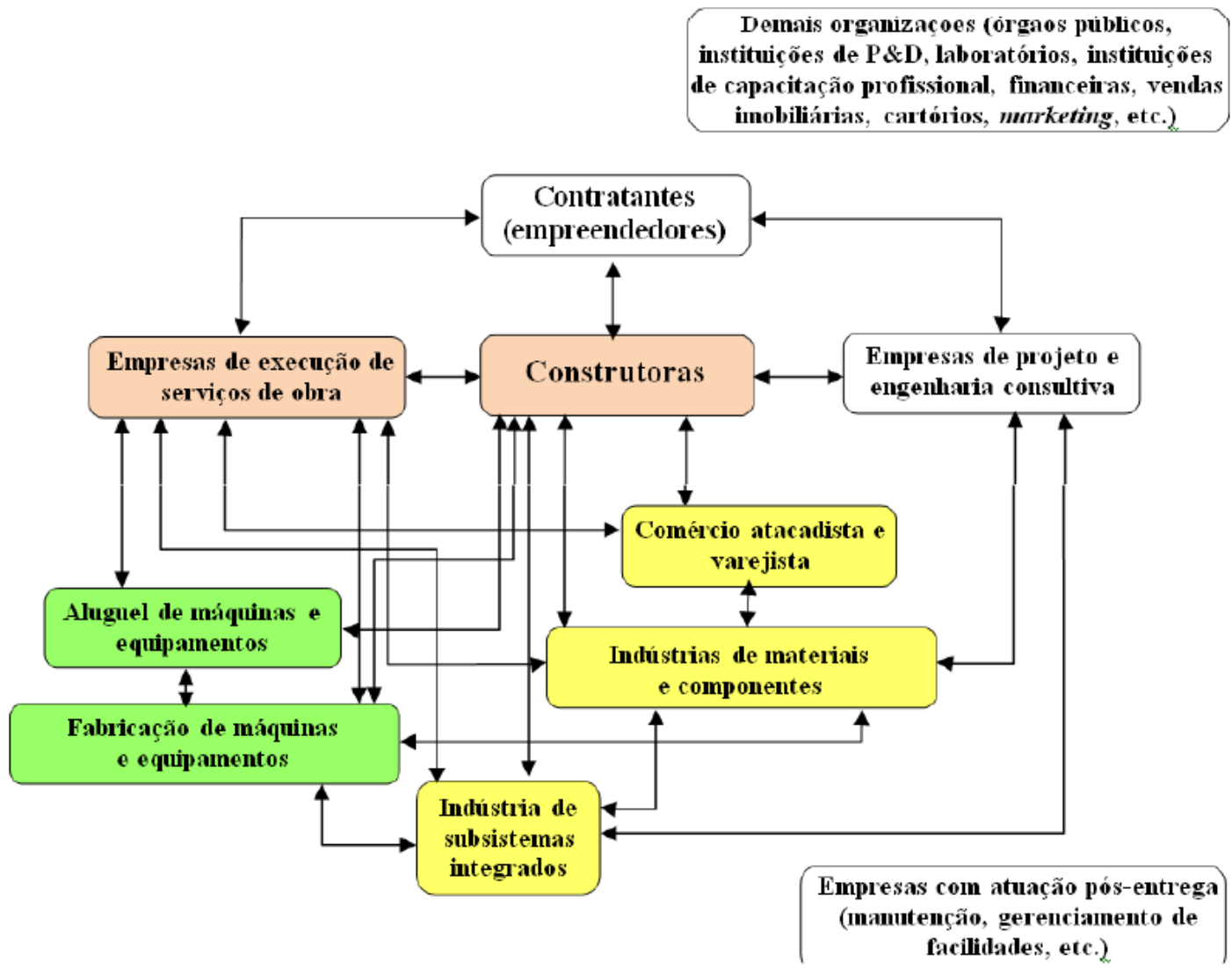

Figura 7 - Estrutura de composição da cadeia produtiva do setor de edificações da indústria da construção civil (slides de PCC5963 - Cadeia produtiva da construção - Tecnologia, sustentabilidade e inovação, 2015).

A cadeia produtiva do setor de edificações da indústria da construção civil é uma corrente composta por muitos elos, isto é, os agentes. As empresas construtoras e incorporadoras, as empresas executoras de serviços de obra, os segmentos da indústria de transformação que produzem materiais de construção, os segmentos do comércio varejista e atacadista que atuam no setor e as empresas que realizam várias atividades de prestação de serviços, tais como serviços técnico-profissionais, serviços financeiros e seguros são exemplos de agentes da cadeia produtiva do setor de edificações da indústria da construção civil.

Para Abiko et. al. (2005), também são agentes dessa cadeia as administrações municipal, estadual e federal, as concessionárias de serviços públicos, os investidores e agentes financeiros, as empresas imobiliárias, os empreendedores, as empresas de projeto e engenharia consultiva, os consultores especializados, os fabricantes de materiais, componentes e sistemas, os fornecedores de subsistemas integrados, os laboratórios de ensaios, os organismos de certificação, as instituições de ensino e pesquisa, empresas de gerenciamento de obras, empresas de marketing e pesquisa de mercado, empresas de manutenção predial, empresas de serviços condominiais, empresas de gerenciamento de facilities, empresas de comissioning, seguradoras e re-seguradoras, clientes finais e etc. 
Na cadeia produtiva do setor de edificações, as empresas construtoras são, em geral, as responsáveis pela gestão do processo de produção do empreendimento (SERRA, 2001; PEREIRA, 2003), delegando a execução das várias atividades a outras empresas, denominadas empresas executoras de serviços de obras (EES). As EES “são aquelas constituídas por um conjunto de profissionais e de recursos agrupados sob uma mesma entidade jurídica para executar, graças a seus próprios meios, uma ou mais partes ou subsistemas do edifício e que, para tanto, utiliza técnicas, métodos, processos e conhecimentos específicos" (CARDOSO, 2003).

O impacto das EES no desempenho econômico da indústria da construção civil como um todo é bastante relevante. Ao analisar o setor de edificações da indústria da construção no estudo Produtividade da Construção Civil Brasileira CBIC (2012), nota-se que, entre 2007 e 2012, o desempenho do segmento de serviços especializados para construção, que engloba as EES, foi bastante inferior ao apresentado pelo segmento de edificação, que engloba as empresas construtoras. Enquanto estas apresentaram aumento de $0,6 \%$ ao ano na PTF, no segmento de serviços especializados para construção, a PTF diminuiu 3,3\% ao ano, acumulando redução de 15,6\% no período (Figura 8). Este cenário sugere que as EES sofreram severas dificuldades para controlar custos e manter a rentabilidade de suas operações.

\begin{tabular}{|lcccc|}
\hline Segmento & Periodo & $\begin{array}{c}\text { Produto / } \\
\text { Trabalhador }\end{array}$ & $\begin{array}{c}\text { Produto / } \\
\text { Capital }\end{array}$ & $\begin{array}{c}\text { Produtividade Total dos } \\
\text { Fatores }\end{array}$ \\
\hline $\begin{array}{l}\text { Todas as } \\
\text { Empresas }\end{array}$ & $2007 / 2012$ & $-0,2 \%$ & $-0,5 \%$ & $-0,4 \%$ \\
\hline Edificaçāo & $2007 / 2012$ & $0,6 \%$ & $0,7 \%$ & $0,6 \%$ \\
\hline Infraestrutura & $2007 / 2012$ & $1,0 \%$ & $-0,1 \%$ & $0,5 \%$ \\
\hline Serv.Especializados & $2007 / 2012$ & $-3,2 \%$ & $-2,6 \%$ & $-3,3 \%$ \\
\hline
\end{tabular}

Figura 8 - Produtividade dos fatores de produção (trabalhador e capital) e produtividade total dos fatores por segmento de atividade (\% ao ano) (CBIC, 2012).

CBIC (2012) ainda destaca que a expansão das contratações nas EES foi vertiginosa, passando de 328 mil trabalhadores em 2007 para 706 mil em 2012 (aumento de 115\% ou 16,5\% ao ano). Essa foi a resposta rápida encontrada por essas empresas para atender ao aumento da demanda por serviços e à exigência do cumprimento de prazos. $\mathrm{O}$ investimento nestas empresas acompanhou essa expansão e aumentou 329\% no mesmo período. Só entre 2011 e 2012, ele passou de $\mathrm{R} \$ 9,7$ bilhões para $\mathrm{R} \$ 19$ bilhões, um aumento de $82 \%$.

No entanto, o aumento do investimento não foi equivalente ao aumento do número de trabalhadores e, como consequência, as EES sofreram fortes perdas de produtividade. Desta 
forma, dada a forma com que empresas construtoras e EES estão inseridas na cadeia produtiva do setor e como atuam no processo de produção dos empreendimentos, é possível que a redução das margens de lucro das construtoras tenha origem na queda de produtividade das EES.

Uma das causas dessa queda de produtividade diz respeito à falta de competências técnica e organizacional das EES para o uso de novas tecnologias. Em geral, ao contratar uma EES, a empresa construtora passa a se preocupar mais com o nível de produção e o prazo da obra e menos com a avaliação da qualificação dos recursos humanos da empresa contratada e com o domínio ela tem da inovação. Dessa forma, mesmo quando são propostas inovações, estas são pontuais e raramente conseguem romper com a ordem de grandeza da produtividade do serviço tradicional. O processo construtivo continua essencialmente o mesmo, pois as formas de relacionamento e organização do processo de produção entre agentes da cadeia produtiva impedem avanços mais contundentes na produtividade (BARROS 1996; CBIC, 2012; BARROS e ARAÚJO, 2014).

Assim, a pergunta que esta dissertação busca responder é: quais diretrizes podem ser adotadas pelo subconjunto mais organizado de EES, isto é, pelas empresas de execução especializada de serviços de obra (EEE), a fim de estimular seu desenvolvimento por meio da adoção de uma estratégia que possibilite a prática sistemática da inovação dentro da empresa?

\subsection{Justificativa}

É possível combater a queda sistemática da produtividade do setor de serviços especializados para a construção civil por meio do estímulo à prática sistemática da inovação nas EEE.

O estímulo a novas ofertas de serviço, por exemplo, é uma alternativa para evitar as disputas por menor preço e as condições predatórias de competição a que frequentemente acabam submetidas. Desta forma, estabelecer diretrizes estratégicas para torná-las mais inovadoras pode contribuir que estas empresas superem os desafios de produtividade e as difíceis condições de competição e concorrência que enfrentam no setor.

Quando uma empresa decide inovar ela, basicamente, altera o funcionamento de um ou mais componentes de seu modelo de negócio. É uma disciplina relativamente nova, pouco explorada, bastante abrangente e, como se verá adiante nesta dissertação, é capaz de afetar a empresa como um todo.

A estratégia com foco na inovação é, em geral, abordada por áreas de administração de empresa, mais focadas em indústrias manufatureiras, que não conseguem analisar a inovação 
como estratégia dentro do contexto da prestação de serviços de construção civil. Dessa forma, esta dissertação pretende explorar um pouco mais este tema no âmbito desse setor.

O entendimento do impacto econômico provocado pela inovação ainda é deficiente. Isso acontece porque as estatísticas oficiais são obtidas a partir das diretrizes do OCDE (2004), que utiliza informações como porcentagem do orçamento anual da empresa destinado a áreas de pesquisa e desenvolvimento e quantidade de patentes geradas para compor indicadores para mensurar a inovação, descartando inovações provenientes de outras fontes, como marketing ou serviços (KALATUNGA, AMARATUNGA e HAIGH, 2006). Apesar das estatísticas oficiais considerarem apenas indicadoras da área de $\mathrm{P} \& \mathrm{D}$, esta é uma, mas não a única fonte de inovação de uma empresa.

Por exemplo, Slaughter (1991) mostra que a maioria das inovações tem origem no canteiro de obra, por lá estarem os usuários finais das tecnologias de construção. Informações como estas não são contabilizadas nos indicadores oficiais e, talvez por isso, ainda sejam pouco compreendidas.

Tal constatação é corroborada por outra fonte. Em um relatório denominado The Innovation Gap, publicado em 2006 pela a organização britânica National Endowment for Science, Technology and the Arts, os pesquisadores enfatizaram que as chamadas hidden innovation, atividades de inovação que não constavam dos indicadores tradicionais de inovação das empresas, como o investimento em P\&D e a quantidade de patentes concedidas, estavam ganhando cada vez mais importância, especialmente no setor de serviços (TIDD e BESSANT, 2013).

Quando se trata de inovação de serviços, a avaliação de sucesso é mensurada de outras formas, algumas relacionadas a aspectos financeiros, como volume de vendas, participação de mercado e margens de lucro algumas relacionadas a aspectos não financeiros, como o aprimoramento do relacionamento com os clientes, aumento da fidelidade, aumento de vendas de outros produtos, atração de novos clientes, reposicionamento da empresa, melhoria de imagem, abertura de novos mercados, desenvolvimento de plataformas para novos produtos entre outros (COOPER et al. 1994 apud FREDERICK, 2010).

Inovação de modelo de negócio, inovação de serviços, startups são realidades ainda distantes das empresas do setor de construção civil. Estudos abordaram tais temas no âmbito das construtoras, mas a análise nunca foi estendida às EES. No entanto, como descrito a seguir, há aspectos na operação de startups que se assemelham à aspectos na operação das EES, como a necessidade de inovar por meio da criação de novos produtos ou serviços e as condições de incerteza nas quais operam. 


\subsection{Objetivos}

O objetivo primário desta dissertação é identificar na literatura um processo adequado para definir diretrizes para formulação de uma estratégia para desenvolvimento de empresas de execução especializada de serviços de obras (EEE) com foco na inovação.

Como objetivos secundários, tem-se:

- Identificar as características de empresas inovadoras, enfatizando aspectos relacionados à estratégia e à estrutura organizacional adotadas por elas para praticar a inovação de forma sistemática;

- Exemplificar a aplicação do método de planejamento estratégico na definição de diretrizes para formulação de uma estratégia de inovação em uma empresa de execução especializada de serviços de obra (EEE) de alvenaria

\subsection{Método de pesquisa}

Considerando que a dissertação se situa no âmbito do Programa de Mestrado Profissional de Inovação na Construção Civil - ConstruInova, ela foi desenvolvida com o intuito de abordar temas de áreas não familiares ao autor e que se apresentavam como lacunas de conhecimento relevantes frente aos desafios impostos em sua atuação profissional em áreas de desenvolvimento tecnológico e inovação em uma empresa construtora e em uma empresa de execução especializada de serviços de obra de alvenaria.

Para atingir os objetivos primários e secundários desta dissertação, buscou-se compreender, na literatura, conceitos de administração, estratégia e inovação de modo a identificar um processo de planejamento estratégico adequado para definir diretrizes para formulação de uma estratégia de inovação em uma empresa de execução especializada de serviços de obra (EEE) de alvenaria.

\subsubsection{Considerações sobre o método no capítulo "Administração, estratégia e organização de empresas"}

Para compreender alguns fundamentos que sustentam o processo de planejamento estratégico de uma empresa, tal processo foi abordado sob três óticas diferentes: duas baseadas em teorias tradicionais da administração, que são a teoria neoclássica e a teoria da contingência, e outra baseada em um conceito mais atual, o conceito de modelo de negócio. As principais referências foram Porter (1989; 1996), Chiavenato (2004) e McGrath (2010). 
O processo de planejamento estratégico que utiliza o conceito de modelo de negócio é mais adequado para mercados imprevisíveis, modeláveis e competitivos, como os que as EEE atuam. Neste item, é apresentada uma ferramenta de representação visual do funcionamento do modelo de negócio de uma empresa bastante útil, desenvolvida por Osterwalder e Pigneur (2011) e denominada Quadro de Modelo de Negócio (Business Model Canvas). Tal ferramenta constitui meio adequado à construção de cenários e à comparação de estratégias distintas, aprimorando o processo decisório até a escolha da melhor estratégia. O processo de planejamento estratégico utilizando o Quadro de Modelo de Negócio é particularmente interessante por também permitir definir diretrizes para formulação de estratégias de inovação.

Por fim, é descrita a estrutura organizacional básica de uma EEE e as influências que tipos diferentes de ambiente e estratégia exercem sobre ela.

\subsubsection{Considerações sobre o método no capítulo "A prática da inovação nas empresas"}

A partir da compreensão dos fundamentos que sustentam o processo de planejamento estratégico de uma empresa e da identificação de um processo adequado ao mercado imprevisível, modelável e competitivo na qual atua uma EEE de alvenaria, a etapa seguinte da dissertação abordou a inovação.

São apresentadas as diversas interpretações do termo, segundo diferentes formas de classifica-lo (inovação tecnológica e não tecnológica, inovação quanto ao objeto, inovação quanto ao grau de novidade, inovação quanto ao objeto focal, inovação quanto ao grau de difusão). A principal referência é OCDE (2004).

Em seguida, aborda-se a estratégia de inovação, ressaltando o vínculo que ela deve ter com a estratégia "global" da empresa, apesar de serem conceitos diferentes. Então, são apresentados os três Horizontes de Inovação, bem como um processo de planejamento da estratégia de inovação. As principais referências são Blank (2015) e Baghai, Coley e White (2000).

A fim de identificar características necessárias ao desenvolvimento da inovação em EEE, estudou-se as características das empresas inovadoras encontradas na literatura, utilizando como referências principais OCDE (2004), Terra (2012) e Tidd e Bessant (2012). Em geral, empresas inovadoras apresentam um modelo de gestão específico, contendo uma estratégia, uma estrutura, uma cultura e um corpo de profissionais especialmente voltados para a inovação.

Em seguida, mostra-se as adaptações recomendadas na estrutura organizacional para as empresas que pretendem adotar estratégias com foco em inovação. 


\subsubsection{Considerações sobre o método no capítulo "Estratégia e inovação em uma empresa de execução especializada de serviços de obras de alvenaria"}

A partir da identificação na literatura de um processo de planejamento estratégico adequado a mercados imprevisíveis, modeláveis e competitivos, da forma de elaboração da estratégia de inovação e da identificação das características de empresas inovadoras, o autor desta dissertação buscou adaptá-los à realidade da EEE onde atuava.

Neste capítulo, é descrito o papel dessas empresas na indústria da construção civil, explicitando as características que as distinguem da grande maioria das empresas com base em Cardoso (2003) e Oviedo Haito (2010, 2015). São feitas considerações a respeito da natureza da inovação em EEE com base na experiência profissional do autor desta dissertação e na literatura sobre inovações em serviços e, por fim, aplica-se o processo de planejamento estratégico para definir diretrizes de três estratégias de inovação distintas: uma para inovação no Horizonte 1, outra para inovação no Horizonte 2 e outra para inovação no Horizonte 3. O autor desta dissertação teve a oportunidade de participar em dois destes três processos.

\subsection{Estrutura do texto}

O texto desta dissertação está dividido em seis capítulos.

No Capítulo 1 tem-se a introdução e a justificativa para a escolha do tema, os objetivos principais e secundários e o método de pesquisa.

No Capítulo 2 tem-se várias definições e interpretações do termo "estratégia", o processo de planejamento estratégico para as teorias neoclássica e de contingência da administração são descritos e o processo de planejamento estratégico para mercados imprevisíveis, modeláveis e competitivos utilizando o Quadro de Modelo de Negócio (Business Model Canvas). Por fim, são descritas características básicas da estrutura organizacional de uma empresa e a influência causada pela adoção de diferentes estratégias.

No Capítulo 3 tem-se as motivações que levam as empresas a inovar, as vantagens obtidas pelas empresas que inovam, as vantagens e desvantagens de inovar em uma empresa de menor porte e como o ambiente das empresas afeta a forma de inovar. Em seguida, são descritas as várias definições e interpretações do termo "inovação" e o processo de planejamento estratégico utilizando os conceitos de Quadro de Modelo de Negócio e Horizontes de Inovação. Em seguida, tem-se um compilado das características das empresas inovadoras e a maneira pela qual a prática sistemática da inovação influencia a estrutura organizacional.

No Capítulo 4 tem-se uma explicação de como EEE estão inseridas no setor de edificações, uma caracterização da estrutura organizacional e dos macroprocessos das EEE, 
uma discussão a respeito da natureza de serviço das inovações em EEE e a aplicação do processo de planejamento estratégico da inovação em três casos reais.

No Capítulo 5 tem-se os resultados da pesquisa, considerações genéricas sobre a prática da inovação em empresas e considerações específicas sobre a prática da inovação em uma EEE de alvenaria de vedação.

\section{Considerações sobre administração, estratégia e organização de empresas}

Empresas são organizações constituídas por pessoas e por uma série de recursos não humanos que, em sua essência, visam lucro por meio da realização de atividades com o intuito de produzir produtos ou prestar serviços.

Quando o número de pessoas trabalhando nas atividades de uma empresa aumenta, ou seja, quando ela atinge certo porte, a necessidade de organização também aumenta e elas passam cada vez mais a requerer a condução racional de atividades, ou seja, de administração. Seja ela uma grande indústria, um hospital, uma organização não-governamental, uma empresa construtora ou uma empresa de execução de serviços de obras.

A administração, para ser bem-sucedida depende, fundamentalmente, das habilidades de seu líder. Segundo Chiavenato (2004), ele deve reunir um conjunto de habilidades técnicas (como o conhecimento e familiaridade na execução de técnicas relacionadas às suas atividades), humanas (como a facilidade de comunicação e a de relacionamento interpessoal) e conceituais (como as relacionadas à facilidade de se trabalhar com ideias e teorias abstratas), além da capacidade de analisar situações, de propor soluções e de tomar decisões. Em geral, há um vínculo visceral entre a empresa e seu líder que, naturalmente, acaba transferindo para ela traços particulares de sua personalidade que podem beneficiar ou prejudicar sua administração.

Ao investigar as características qualitativas de várias empresas de execução de serviços de obra que atuavam no segmento de edificações, Cardoso (2003) encontra alguns obstáculos à administração bem-sucedida relacionados à liderança nessas empresas. Segundo o autor, eles têm "um forte envolvimento pessoal na empresa", mas a maioria delas "não são administradas por profissionais" e "funcionam como um campo de treinamento" de operários e líderes.

Limitações como estas mostram que muitas dessas empresas ainda carecem de lideranças mais bem capacitadas e aptas realizar a condução racional de atividades de que suas empresas necessitam. Esta dissertação, no entanto, não foi elaborada visando este público, mas visando as lideranças de empresas de execução de serviços de obras já capacitadas a administrá- 
las, mas que buscam dar um passo adiante em suas empresas por meio da prática sistemática da inovação em suas empresas.

Para isso, serão apresentados, inicialmente, alguns fundamentos que sustentam a prática da administração como a estratégia, o processo de planejamento estratégico e a estrutura organizacional de empresas. A boa administração é requisito para a inovação.

\subsection{As diversas faces da estratégia}

O termo "estratégia" é tão corriqueiro que sua definição, num primeiro momento, parece ser desnecessária. O dicionário Michaelis apresenta quatro definições que acabam revelando as origens militares do termo, cunhado na Grécia Antiga e, atualmente, adaptado às mais diversas situações, sendo uma das palavras mais frequentemente utilizadas no contexto empresarial.

Isso pode não ser um problema nas tratativas do cotidiano, mas no âmbito acadêmico a inexistência de uniformidade do conceito pode causar confusão. Desta forma, este item abordará algumas dessas intepretações no âmbito da administração de empresas

Drucker (1973) a encarava como um conjunto de decisões a serem tomadas no presente visando ao futuro que, obviamente, é incerto e repleto de riscos. Na definição formal, é um processo contínuo, sistemático e racional de tomada de decisões envolvendo riscos no presente visando atingir resultados no futuro. Para isso, são necessários organizar sistematicamente o trabalho necessário a concretizar essas decisões, que devem estar associadas a critérios mensuráveis para poderem ser comparados aos resultados por meio de mecanismos organizados de retroalimentação de informação. Portanto, para este autor, estratégia não é tentar prever o futuro, não é pensar nas decisões que deverão ser tomadas no futuro e também não é uma maneira de eliminar riscos.

Henderson (1989), por sua vez, interpreta-o como uma forma de planejamento das mutações necessárias à evolução das empresas, isto é, a estratégia é uma busca deliberada por um plano de ação capaz de gerar vantagem competitiva para a empresa. Tal busca é um processo iterativo que se inicia com o reconhecimento da empresa: onde ela está e o que ela tem no momento. As diferenças entre ela e os competidores com propostas de valor mais parecidas formam as bases de vantagem competitiva. Se uma empresa for capaz de se auto sustentar, então ela possui algum tipo de vantagem competitiva pois, caso contrário, ela perderia clientes mais rápido do que ganharia. Para o autor, o objetivo de se adotar uma estratégia é expandir a vantagem competitiva de uma empresa em relação às rivais e isso só pode ser obtido às custas das perdas de alguém. 
Para Mintzberg (1994), o termo pode ser aplicado de diferentes maneiras: um modelo de escolhas realizadas ao longo do tempo acerca do futuro de uma empresa, como um plano, que relaciona escolhas a planos de ação, como um posicionamento estratégico de uma empresa, oriundo das escolhas que ela fez sobre as atividades que deverá realizar a fim de produzir produtos ou serviços a serem ofertados em determinados mercados e como uma perspectiva em que o modelo de negócio é elaborado.

Uma das abordagens mais difundidas do termo foi elaborada por Porter (1989), que descreve estratégia como um conjunto de escolhas das atividades que uma empresa deverá desempenhar. Essas atividades, no entanto, devem configurar uma maneira única de se produzir os produtos ou de se prestar os serviços demandados por seus clientes, diferente da praticada por empresas concorrentes. O objetivo é o de entregar algo único e valioso a ele.

Mintzberg, Ahlstrand e Lampel (2000) agrupam as definições do termo em cinco grupos. No primeiro, estratégia é entendida como um plano que indica uma direção, um guia, um curso de ação consciente engendrado para o futuro, um caminho para ir de uma situação atual para uma situação desejada.

Segundo os mesmos autores, ela também pode ser entendida como um padrão ou um modelo, que consiste na manutenção de um determinado comportamento ao longo do tempo. Neste caso, o termo enfatiza o mais o comportamento passado da empresa do que o futuro e, desta forma, não basta planejar, é preciso criar padrões de ação resultantes de planejamento. Em geral, as empresas utilizam modelos de planejamento estratégico que planejam o futuro projetando repetições de comportamento encontradas no passado. Nem sempre tais modelos funcionam pois, muitas vezes, o mercado é tão imprevisível, modelável e competitivo que projetar padrões de comportamento do passado para o futuro é ineficaz.

Outra maneira de interpretá-la é considera-la como uma posição, isto é, um nicho de mercado para inserir a empresa. Esta é a abordagem difundida em Porter (1989).

Por fim, Ovans (2015) propõe uma nova divisão, em três grupos, do vasto universo de interpretações do termo, classificando-a de acordo com o pretendido pela empresa: as estratégias que visam aumentar a eficiência daquilo que elas já fazem, as estratégias que visam que elas façam algo diferente daquilo que já fazem e as estratégias que visam conferir flexibilidade para reagir às oportunidades que elas encontram.

Para esta dissertação, a definição mais adequada é a proposta por Mintzberg, Ahlstrand e Lampel (2000): estratégia é a manutenção de um padrão de comportamento ao longo do tempo. 


\subsection{Fundamentos do processo de planejamento estratégico}

A seguir, serão apresentados os aspectos de três processos diferentes de planejamento estratégico, um sob a luz da teoria neoclássica da administração, outro sob a luz da teoria da contingência da administração e o último incorporando o conceito de modelo de negócio. Segundo Chiavenato (2004) o processo de planejamento estratégico refere-se à maneira pela qual uma empresa elabora uma determinada estratégia visando a atingir os objetivos organizacionais propostos.

O processo de planejamento estratégico da teoria neoclássica da administração é mais antigo e se trata de um modelo prescritivo, formulado na década de 1950 e muito utilizado pelas maiores empresas da indústria manufatureira. Elas operavam em condições de razoável estabilidade: havia demanda razoavelmente constante por seus produtos ou serviços, raramente eram ameaçadas por empresas concorrentes e, em geral, conseguiam encontrar padrões de comportamento do mercado que, se projetados, ofereciam razoavelmente confiáveis sobre o futuro. A estratégia oriunda de um processo como este é, portanto, de longo prazo, visa horizontes de dois a cinco anos e, essencialmente, é enrijecida: raramente a estratégia sofre alterações antes de seu prazo de validade expirar.

O processo de planejamento estratégico da teoria da contingência é mais moderno e consiste num modelo descritivo, formulado na década de 1990 e difundido para empresas de várias indústrias, inclusive as da construção civil. Parte dessa popularidade pode ser explicada pela maleabilidade do modelo, mais adequado para considerar a influência dos aspectos externos à empresa, fontes de instabilidade para ela, na estratégia. São exemplos a queda imprevista de demanda por seus produtos ou serviços, a ameaça causada por empresas concorrentes e a incapacidade de se fazer projeções confiáveis de longos horizontes de tempo utilizando-se como base padrões de comportamento encontrados no passado. A estratégia oriunda de um processo como este, portanto, deixou de ser de longo prazo e passou a ser mais maleável: não é incomum alterar a estratégia antes de seu prazo de validade expirar para considerar algum aspecto de mercado imprevisto.

A partir dos anos 2000, a administração das empresas passou a ser ainda mais influenciada pelo ambiente externo a elas, tornando a estratégia ainda mais necessária para que as empresas atinjam seus objetivos organizacionais. Segundo Chiavenato (2004), os conceitos de estratégia têm se tornado mais voláteis e quanto mais os ambientes externos se tornam dinâmicos e modeláveis, mais as empresas precisam de estratégia para integrar seus objetivos, políticas e ações de maneira coerente. 
Reeves, Love e Tillmanns (2012) descrevem o resultado de um estudo sobre como o ambiente externo interfere no processo de planejamento estratégico de 120 empresas de 10 segmentos diferentes ao redor do mundo. Para os autores, a definição da estratégia se inicia com a escolha do processo de planejamento estratégico mais adequado às características do ambiente externo das empresas.

Esta escolha depende de uma avaliação da previsibilidade e da maleabilidade da indústria em que a empresa está inserida. A previsibilidade está associada ao tamanho do horizonte futuro de tempo em que é possível projetar expectativas e demanda do mercado, desempenho operacional da empresa e as dinâmicas e condições de concorrência a que ela será submetida. A maleabilidade está associada ao quanto os concorrentes conseguem influenciar tais fatores.

Para os autores, é possível caracterizar cinco estilos diferentes de processos de planejamento estratégico: quatro que dependem da previsibilidade e da maleabilidade do mercado em que a empresa atua (clássico - classical, visionário - visionary, adaptativo adaptative, modelável - shaping) e um que pode ser adotado independentemente das características do mercado em que a empresa atua (sobrevivência - survival).

Mercados como os das indústrias farmacêutica e automotiva são previsíveis e pouco modeláveis. Isso significa que as demandas de mercado e as condições de competição e concorrência são relativamente estáveis, o que aumenta a eficácia da previsão de desempenho operacional das empresas e as condições de competição não são facilmente alteradas pela concorrência.

Nestes casos, o estilo de planejamento estratégico mais apropriado é o clássico (classical), em que o objetivo organizacional é definido e algumas estratégias formuladas com base em análises do ambiente externo de negócio, e internas, dos ativos da empresa até que, após sucessivas etapas de análise qualitativa e quantitativa de informações, seja feita a opção por uma única que, graças à previsibilidade do mercado e à baixa influência que a concorrência exerce nele, é utilizada sem grandes alterações, por anos. Tendo em vista as características de ambientes externos de negócio como esses, empresas procuram adotar estratégias baseadas na teoria neoclássica da administração.

Ambientes externos de negócio como os das indústrias alimentícias e hospitalar são previsíveis e modeláveis, isto é, as empresas são capazes de influenciar as condições de competição do mercado em vantagem própria por meio de projeções de demanda e de desempenho operacional com razoável segurança. 
Nestes casos, a previsibilidade do mercado contribui para tornar objetivos e planos mais tangíveis, embasados por informações e, consequentemente, mais confiáveis no longo prazo. Assim, este estilo chamado de planejamento estratégico denominado visionário (visionary) se assemelha ao clássico, mas com uma diferença: o planejamento e a implementação da estratégia requer disciplina e comprometimento com os objetivos organizacionais propostos, pois o ambiente de mercado é modelável e, por isso, influenciáveis por empresas concorrentes. Tendo em vista as características de ambientes externos de negócio como esses, empresas procuram adotar estratégias baseadas na teoria clássica e neoclássica da administração.

Ambientes externos de negócio como os das indústrias de computadores e de materiais de construção são imprevisíveis e pouco modeláveis. Empresas que competem nestas indústrias estão sujeitas a um ambiente externo de negócio em constante alteração pois a concorrência globalizada e a dependência da inovação para o lançamento de novos produtos ou serviços exigem que elas consigam se adaptar rapidamente.

Nestes casos, planejar a estratégia utilizando um estilo clássico não é adequado pois até uma estratégia como essa, detalhada e rica em dados, ser elaborada, as condições de competição já se alteraram e a estratégia já se tornou obsoleta. Assim, os autores recomendam um estilo adaptativo (adaptative) de planejamento estratégico, focado não em aumentar a eficiência, mas em aumentar a flexibilidade da estrutura organizacional da empresa, preparando-a para responder rapidamente às mudanças do ambiente externo de negócio e dos objetivos organizacionais. Tendo em vista as características de ambientes externos de negócio como esses, empresas procuram adotar estratégias baseadas na teoria da contingência.

Um ambiente externo de negócio como o da indústria da construção civil é considerado imprevisível e modelável pois, diferentemente dos anteriores, é fragmentado, difícil de prever demanda e com poucas barreiras para entrada de novos competidores. Outros autores fazem menção à instabilidade do ambiente externo de negócio da indústria da construção civil. Gray e Flanagan (1989) e Shen e Kong (2011), por exemplo, o descrevem como dependente de ciclos econômicos variáveis, o que dificulta projeções de demanda estáveis ao longo do tempo. Essa característica induz à necessidade das empresas adotarem estratégias mais flexíveis e adaptáveis que as estratégias neoclássicas.

Nestes casos, as empresas não têm que se preocupar com a densidade de dados necessária para elaborar uma estratégia de longo prazo como prega o estilo clássico, nem em responderem rapidamente a novas tendências e inovações do mercado. Assim, tendo em vista a imprevisibilidade da demanda e a influência que as empresas atuantes nesse segmento têm nas condições de competição, os autores recomendam adotar um estilo modelável (shaping) de 
planejamento estratégico, cujo objetivo é influenciar em benefício próprio os rumos de um mercado repleto de incertezas. A estratégia deve ser revisada em intervalos curtos de tempo, focada em dar flexibilidade à estrutura organizacional da empresa e em fazer pequenas experiências de parceria com clientes e fornecedores de modo a testar novos modelos de negócio no intuito de romper com paradigmas atuais do mercado e estabelecendo as regras da nova condição de competição. Tendo em vista as características de ambientes externos de negócio como esses, empresas procuram adotar estratégias baseadas na teoria da contingência.

O último estilo de processo de planejamento estratégico, que independe das características do mercado em que a empresa atua é o de sobrevivência. Empresas adotam estratégias de sobrevivência quando não tem acesso a capital ou a outros recursos que são críticos à sua própria operação, assumindo uma postura defensiva: reduzindo custos, preservando o caixa, adiando a execução de projetos de inovação. Estratégias como essa devem ser, necessariamente, de curto prazo, para fazer com que a empresa atravesse um momento de crise econômica, por exemplo. Se adotadas por muito tempo elas ameaçam a existência futura da empresa por reduzir ou eliminar ações no presente visando seu crescimento no futuro.

Para Ries (2011), há certa fascinação associada a um bom plano, mas eles não funcionam se aplicados a empresas que operam em ambientes externos repletos de incerteza. Segundo o autor, a medida em que as incertezas aumentam, os processos tradicionais de planejamento estratégico não são mais capazes de prever o futuro porque o planejamento e a previsão são precisos apenas quando estão baseados num histórico operacional longo e estável de um ambiente relativamente estático.

Assim, a administração de empresas de execução especializada de serviço de obra (EEE) deve acontecer considerando-se que a operação está imersa em um ambiente de muita incerteza. O último processo de planejamento estratégico é o mais atual e incorpora o conceito de modelo de negócio. Trata-se de uma forma de se definir a estratégia visual e ainda mais maleável que a apresentada pelo processo de planejamento estratégico sob a luz da teoria da contingência.

\subsubsection{O processo de planejamento estratégico para a teoria neoclássica da administração}

A teoria neoclássica leva em consideração as novas perspectivas de inovação e de adaptação à mudança. Assim, ela realça tanto aspectos prescritivos, pois trata a administração como um conjunto de processos que visa a atingir objetivos organizacionais estabelecidos, quanto explicativos da teoria. A teoria neoclássica está centrada na empresa e não em seu ambiente externo de negócio. 
A estratégia foi incorporada ao contexto empresarial nessa época, importada do contexto militar. Segundo Chiavenato (2004), neste período as empresas norte-americanas passavam por um momento de pressão estatal, que intervinha em sua operação, tentando controlá-las. Isso causou queda nas margens de lucro, forçando os gestores a reduzir despesas e esforços supérfluos. Isso provocou uma quebra de paradigma em termos de administração pois, pela primeira vez, as pessoas e as organizações não estavam mais tão centradas na tarefa em si, necessária à realização de suas atividades, mas em produzir resultados. Ou seja, o enfoque passou do processo aos objetivos organizacionais das empresas.

Isso inaugurou a chamada administração por objetivos ou administração por resultados: um método em que as metas de uma empresa são definidas pelos gestores em conjunto, que deverão especificá-las a seus subordinados a fim de que atinjam o resultado esperado dentro de um determinado período.

Desta forma, a mudança de enfoque das empresas, passou dos meios (como fazer) para os fins (resultados) provocando alterações significativas no trabalho. Mais do que simplesmente realizar a tarefa necessária à conclusão das atividades de produção de produtos ou de prestação de serviços, os gestores passaram a se questionar quais atividades eram realmente relevantes para que os resultados fossem atingidos. Para isso, a empresa inteira deveria, de alguma maneira, esforçar-se em busca de um objetivo comum. Era necessário um sistema de objetivos organizacionais previamente definidos que pudessem ser dissecados ao longo dos níveis hierárquicos para (e principalmente) as atividades a serem executadas no nível operacional contribuíssem para o atingimento desses objetivos.

Segundo Chiavenato (2004), o modelo prescritivo do planejamento estratégico da corrente teórica da administração por resultados segue cinco etapas. As bases do planejamento estratégico para a teoria neoclássica foram representadas na Figura 9.

- Formulação dos objetivos organizacionais, em que a empresa escolhe os objetivos que pretende alcançar no longo prazo e define uma ordem de prioridades;

- Análise externa do ambiente, em que são mapeadas as condições do ambiente externo de negócio da empresa, as características atuais e tendências futuras dos mercados que ela atende, a concorrência e as conjunturas técnica, políticas e econômicas, no intuito de se fazer, da melhor maneira possível, um conjunto de previsões acerca do futuro de tais condições;

- Análise interna da empresa, isto é, uma análise dos ativos, formado pelo conjunto de ativos estratégicos de que uma empresa dispõe para realizar sua 
operação atual ou futura (recursos financeiros, equipamentos, matérias-primas, recursos humanos, tecnologia, etc.), da estrutura organizacional (aspectos positivos e negativos, divisão de trabalho entre departamentos e maneira pela qual os objetivos estratégicos foram desdobrados em objetivos táticos) e do desempenho (lucratividade, produção, produtividade, inovação, crescimento e desenvolvimento da empresa) no intuito de identificar forças e fraquezas que contribuem ou atrapalham o atingimento dos objetivos organizacionais da empresa. Uma das ferramentas mais conhecidas para este tipo de análise, que é combinada uma análise externa do ambiente é a chamada análise SWOT, atribuída a Albert Humphrey, da Universidade de Stanford;

- Formulação das alternativas estratégicas e escolha da estratégia a ser utilizada tendo em vista os objetivos organizacionais formulados, a análise externa do ambiente e a análise interna da empresa. As alternativas estratégicas são os cursos de ação que a empresa irá adotar para atingir seus objetivos;

- Desenvolvimento do planejamento tático e operacionalização da estratégia. Nesta etapa, a estratégia escolhida é desdobrada em planejamentos táticos em que os objetivos devem ser quantificados, mensurados e controlados para que se consiga comparar aquilo que foi planejado com o resultado daquilo que foi executado.

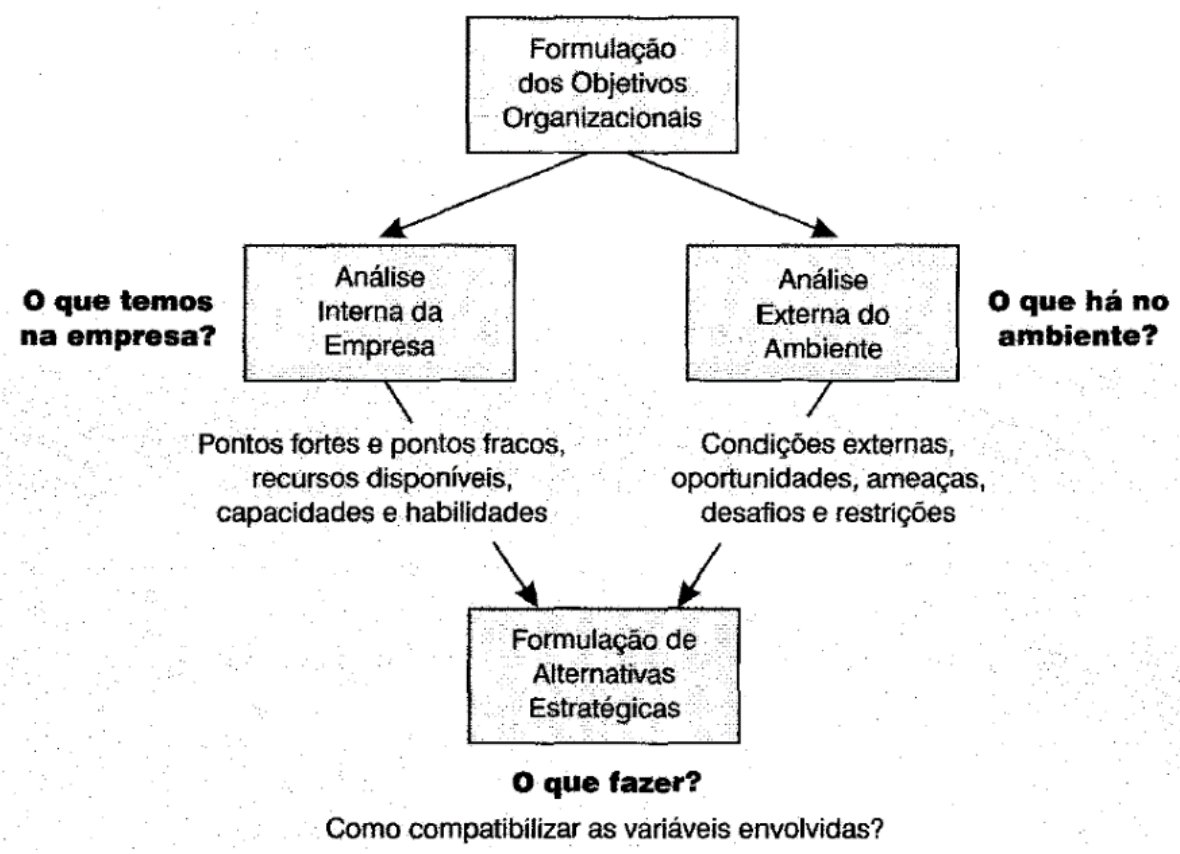

Figura 9 - As bases do planejamento estratégico para a teoria neoclássica (CHIAVENATO, 2004) 
Segundo o autor, as principais características necessárias a uma administração por resultados são:

- Estabelecimento conjunto de objetivos entre o gestor e superior;

- Estabelecimento de objetivos para cada departamento ou posição;

- Interligação entre os vários objetivos departamentais;

- Ênfase na mensuração e no controle de resultados;

- Contínua avaliação, revisão e reciclagem dos planos;

- Participação atuante dos gestores e dos subordinados.

Note que nem todas estas características estão presentes ou não são aplicáveis ao conjunto das EES. Por exemplo, a interligação entre os vários objetivos departamentais pode não ser aplicada ao conjunto das SE porque todas estas funções administrativas podem estar concentradas em uma única pessoa: o dono (CARDOSO, 2003; OVIEDO HAITO, 2010). Outras vezes, não é possível garantir a ênfase na mensuração e no controle porque têm graus de burocratização baixíssimos em função da pouca formalização por meio de documentação (CARDOSO, 2003). Tal fato pode comprometer o bom andamento do processo de administração por resultados ao obscurecer as avaliações objetivas, pautadas em indicadores, dando vazão a análises subjetivas, que se embasas mais nas sensações e experiência dos donos das EES.

Isso é particularmente importante nesse tipo de administração. Chiavenato (2004) explica que em todos os níveis hierárquicos da administração (estratégico, tático e operacional) torna-se necessário mensurar os resultados atingidos e compará-los aos resultados planejados. Se não há planejamento, as metas não são definidas e os resultados não são comparáveis a nada. Por outro lado, se há planejamento e, consequentemente, metas, mas os resultados obtidos são medidos, é impossível saber se a meta foi atingida.

Dessa forma, para buscar a inovação, EES precisam, necessariamente, ter um planejamento estratégico sistemático que defina metas objetivas, isto é, que estejam associadas a números. Essas metas, por sua vez, devem ser comparadas aos resultados obtidos em seus sistemas de produção. Portanto, necessariamente as empresas devem estabelecer indicadores e, periodicamente, coletar as informações para compô-los e utilizá-los para o desempenho de gestores e subordinados naquele período. A partir dessa avaliação conjunta, o processo se recicla: objetivos são revistos e recursos e competências redimensionados. Como se verá a seguir, este tipo de organização, no entanto, só é encontrado em EEE. 


\subsubsection{O processo de planejamento estratégico para a teoria da contingência da administração}

A partir da década de 1990, a estratégia passou a sofrer novas transformações. Com o advento dos computadores, da internet e da tecnologia da informação, as mudanças e transformações no ambiente externo de negócio das empresas passaram a acontecer cada vez mais rápido. Tais mudanças não eram mais como antes, sequenciais, resultados de um processo de bons planejamentos estratégico, tático e operacional que foram bem executados. Uma simples projeção do passado passou a não ser mais suficiente para definir uma estratégia pois as mudanças eram tão abundantes que o futuro não se assemelhava mais ao passado (CHIAVENATO, 2004). Caberia à empresa procurar compatibilizar suas condições internas ao ambiente externo para poder tirar vantagens das circunstâncias.

A abordagem mais moderna da administração geral é a chamada teoria da contingência. O termo contingência refere-se àquilo que é incerto, duvidoso, que pode ou não acontecer e que somente a experimentação é capaz de revelar.

Esta abordagem prega que há nada de absoluto nas empresas e tanto sua estrutura organizacional quanto seu funcionamento são dependentes da interface com o ambiente externo, ou seja, não há uma maneira única de organizá-las, tudo depende das condições impostas pelo ambiente externo de negócio. De acordo com ela, dado um determinado mercado, existe um conjunto de técnicas administrativas que são mais apropriadas para uma empresa alcançar seus objetivos. Assim, mudanças no ambiente requerem que as empresas adotem novas estratégias e essas novas estratégias levam a novas estruturas organizacionais.

Uma das escolas mais famosas da abordagem contingencial da administração é a escola do posicionamento, cujo principal expoente é o professor norte-americano Michael Porter. Porter (1989) propõe que a estratégia deve ser baseada na estrutura do ambiente externo no qual as empresas operam. $\mathrm{O}$ famoso modelo das cinco forças de Porter analisa as barreiras a serem superadas por empresas que desejam entrar em determinado mercado, o poder de negociação que os fornecedores da empresa terão, o poder de negociação dos clientes com base nas características do produto ou serviço que eles valorizam, que varia dependendo do quanto costumam comprar, do quão bem informados estão e de sua disposição para experimentar alternativas, a ameaça que a empresa sofrerá de produtos ou serviços substitutos aos dela e as condições de competição, que variam conforme a intensidade da rivalidade entre as empresas de um determinado mercado (Figura 10). 


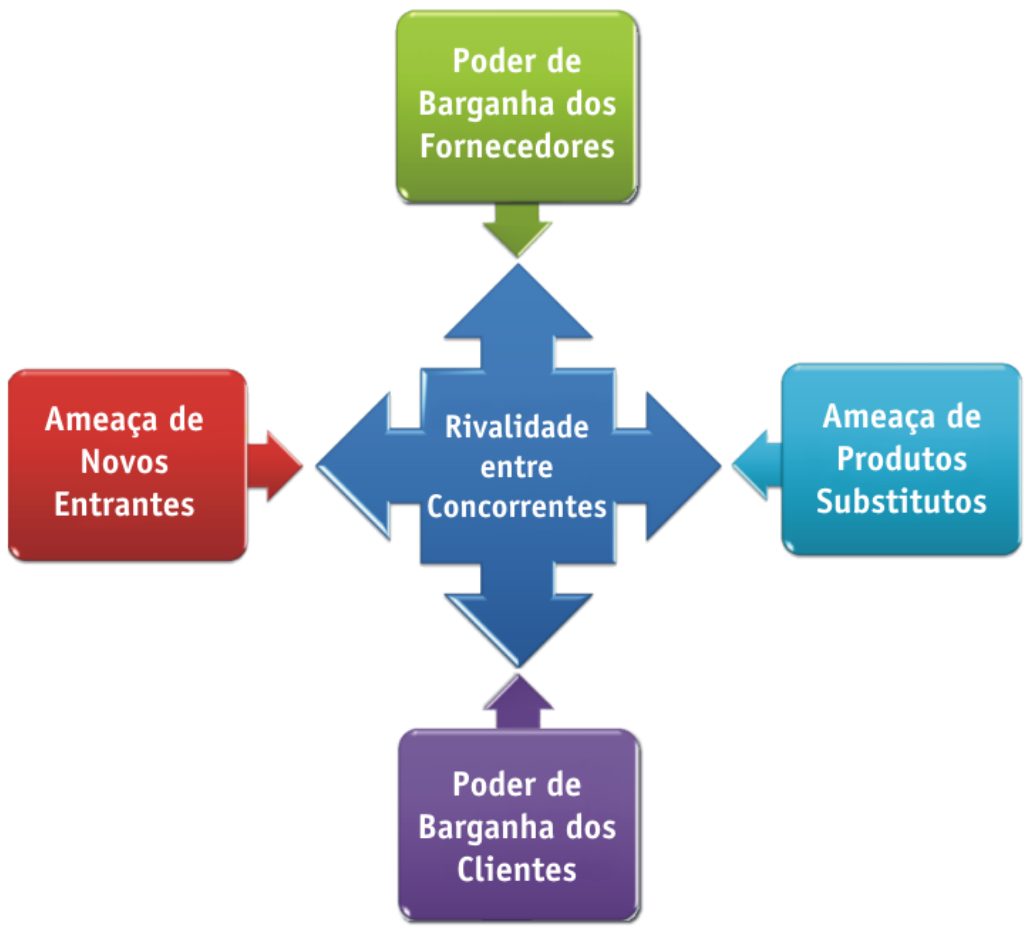

Figura 10 - As cinco forças de Porter (Figura extraída de https://pt.wikipedia.org/wiki/Cinco_for\%C3\%A7as_de_Porter. Acesso em 13/06/2016).

A partir do diagnóstico do ambiente externo, Porter (1989) sugere a adoção de, essencialmente, duas estratégias, chamadas estratégias genéricas por ele - liderança em custo e diferenciação (a terceira estratégia genérica, a estratégia de enfoque, é uma mistura das outras duas) no intuito de alcançar desempenho operacional acima da média da indústria em que a empresa está inserida.

Para este autor, estratégia é uma configuração de atividades coerentes entre si e com a situação do ambiente externo de negócio, que deve satisfazer, por meio da produção de produtos ou prestação de serviços, um determinado segmento de clientes. Para isso, a empresa deve, então, adotar uma única estratégia competitiva genérica (estratégia de liderança de custo, estratégia de diferenciação ou estratégia de enfoque), que provoque nos clientes a necessidade de adquirir os produtos ou serviços dessa empresa em detrimento dos de suas concorrentes. Quando isso acontece, o autor diz que a empresa adquiriu um posicionamento estratégico único e valioso naquele mercado para aquele segmento de clientes.

Desta forma, é o posicionamento estratégico que determina se a rentabilidade de uma empresa está abaixo ou acima da média do mercado em que atua. Segundo o autor, mesmo que o setor em que se insere seja caracterizado por uma rentabilidade modesta, é possível que uma empresa bem posicionada estrategicamente obtenha altas margens de lucro. 
Para Porter (1996), definir a estratégia requer fazer escolhas. Desta forma, os gestores devem escolher quais e de que forma as atividades deverão ser executadas para encontrar um posicionamento estratégico único e valioso, ou seja, uma combinação de produto ou serviço valioso e barato que maximize a satisfação dos clientes daquele determinado mercado, dadas as condições do ambiente externo de negócio em que ela está submetida.

Assim, dependendo da estratégia genérica escolhida (liderança em custo ou diferenciação), os gestores optam por executar um determinado conjunto de atividades em detrimento de outro, bem como optam por executá-las de uma determinada maneira em detrimento de outra. Uma empresa toma decisões para criar uma diferença clara entre o produto ou serviço dela e o da concorrência. Há duas maneiras disso ser vantajoso para o cliente:

- Quando ele adquire um produto ou serviço por um preço mais baixo que outros similares;

- Quando ele adquire um produto ou serviço único que mais do que compensa um preço mais alto.

Nesses casos, diz-se que empresa teve uma vantagem competitiva sobre outra. No primeiro caso, uma estratégia de liderança de custos originou um conjunto de escolhas que provocou alterações nas atividades da empresa visando a diminuir os custos internos de produção, permitindo que o produto ou o serviço pudesse ser comercializado por preços mais baixos que os da concorrência. No segundo caso, foi uma estratégia de diferenciação que originou um conjunto de escolhas que provocou alterações nas atividades da empresa visando a aumentar um conjunto de atributos valorizados pelo cliente que mais do que compensasse os acréscimos nos custos internos de produção.

Para Porter (1989) todas as diferenças entre as empresas derivam das centenas de atividades necessárias para criar, produzir, vender e distribuir seus produtos ou serviços. Para que um produto ou serviço seja produzido, tais atividades devem ser executadas, gerando-se um custo.

Diferentemente do custo, o preço independe das características de produção, mas do mercado em que o produto ou serviço será comercializado. Assim, para ser viável, os custos para produzi-lo devem ser sempre inferiores aos preços praticados no mercado.

O preço é uma quantia monetária desembolsada pelos clientes para adquirir o produto ou serviço. A aquisição é resultado de uma decisão subjetiva, que leva em consideração atributos econômicos, emocionais, sociais, éticos e ambientais desse produto ou serviço. Este conjunto de atributos é chamado de valor. Assim, a satisfação dos clientes origina-se quando adquirem um produto ou serviço por um preço inferior ao valor percebido por eles. 
Para as empresas, o valor é originário das diferenças na seleção de atividades e nas maneiras diferentes de as executar. As atividades incorporam forma de realização de tarefas, incluindo os tipos de ativos humanos e físicos empregados e os arranjos organizacionais associados.

A diferença econômica entre o valor percebido pelo cliente e o preço do produto ou serviço praticado no mercado corresponde à margem potencial. Já a diferença entre o preço e o custo de produção de um produto ou serviço é chamada de margem (Figura 11).

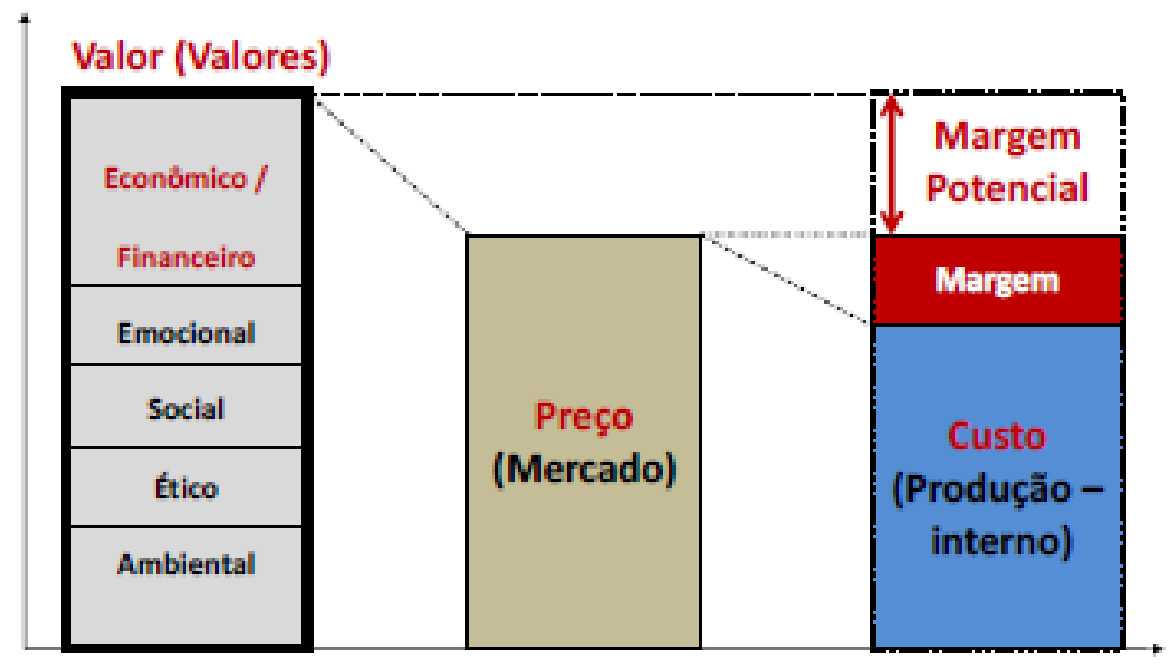

Figura 11 - Valor, preço e margem (Extraído de OVIEDO HAITO, 2015).

Segundo Porter (1996), existem três situações que levam as empresas a obter vantagem competitiva. São elas:

- Executar atividades similares melhor que as rivais (Situação 1);

- Executar atividades similares, mas de formas diferentes das rivais (Situação 2);

- Executar atividades diferentes das rivais (Situação 3).

$\mathrm{Na}$ situação 1, realizar atividades melhor do que as rivais significa ter eficácia operacional. Cardoso (1996) define este termo como a capacidade de alcançar um determinado objetivo. No contexto da indústria da construção civil, uma empresa é eficaz quando, por exemplo, ganha uma concorrência.

Segundo Porter (1996), a eficácia operacional inclui, mas não se limita à eficiência operacional. Cardoso (1996) define eficiência como sendo a capacidade de rendimento de um sistema avaliada qualitativa ou quantitativamente face a um certo nível de recursos de base, como equipamento, homem, capital ou trabalho. Ela se refere a um conjunto de práticas que 
permite que uma empresa utilize melhor seus recursos, ou seja, eficiência operacional é uma medida da produtividade do sistema de produção de uma empresa.

Nas situações 2 e 3, realizar atividades diferentes daquelas das rivais ou realizar atividades similares, mas utilizando métodos diferentes significa que as empresas possuem diferentes posicionamentos estratégicos.

Desta forma, a eficácia operacional é condição necessária, mas não suficiente para a obtenção de desempenho superior em uma empresa. Apesar de garantir vantagem competitiva à empresa por certo tempo, poucas conseguem torná-la duradoura. Segundo Porter (1996), isso acontece porque busca-se eficácia operacional por meio da adoção das melhores práticas disponíveis num determinado momento. Como, em geral, as melhores práticas são soluções genéricas e, portanto, adaptáveis a vários cenários, a vantagem competitiva obtida é passageira. Concorrentes podem rapidamente imitá-las por meio, por exemplo, da contratação de consultores.

Assim, o maior desafio das empresas é criar e manter vantagens competitivas, obtidas pela busca por eficácia operacional e por um posicionamento estratégico único, baseado em um conjunto de atividades adequadas estrategicamente entre si e orientadas ao valor que se deseja criar, e sustentável, que force uma empresa a tomar decisões que provoquem diferenciação dela em relação às rivais aos olhos dos clientes.

Para Porter (1996), negligenciar essa necessidade de posicionamento estratégico é, portanto, um erro, pois as conduz à homogeneização das ofertas de produtos ou serviços de uma empresa. Segundo o autor, o resultado é uma competição estática entre as empresas, que sofrem pressões para reduzir custos, o que diminui margens de lucro e capacidade de investimento a longo prazo da empresa.

Este fenômeno pode ser observado no segmento de edificações, mercado em que atuam as empresas prestadoras de serviços especializados. Após duas dúzias de entrevistas com líderes de diferentes EES de destacada atuação, Oviedo Haito (2010) mostra que a maioria procura imitar o posicionamento estratégico das empresas dominantes, optando por realizar um conjunto de atividades similares aos das rivais. Porém, como descrito por Cardoso (2004), em geral, possuem menor capacidade de produção; não realizam economias de escala; empregam tecnologias simples e tradicionais; têm dificuldade de acesso à inovação; possuem capacidade de inovação limitada; investem pouco em pesquisa e desenvolvimento. Assim, suas ofertas tornam-se commodities, acirrando a disputa pelo menor preço, que historicamente vigora no setor. 
Para Kim e Mauborgne (2005), a "commodização" acelerada de produtos ou serviços, a intensificação da guerra de preços e o encolhimento das margens de lucro sugerem que o ambiente externo de negócio tradicional está entrando em colapso. A alta taxa de mortalidade das EES corrobora a afirmação que, segundo Oviedo Haito (2010) é da ordem de $50 \%$ no quarto ano de operação.

Para Porter (1996), as empresas precisam aprofundar seu posicionamento estratégico oferecendo, por exemplo, produtos ou serviços difíceis de serem copiados pela concorrência. Muitas organizações sucumbem à tentação de buscar o crescimento de maneira simples, nãosustentável, ao almejar novos clientes e mercados em que a empresa tenha pouco de especial a oferecer. Assim, uma alternativa é aprofundar a posição estratégica que a empresa ocupa, o que implica em diferenciar cada vez mais as atividades desempenhadas por uma empresa das atividades desempenhadas por empresas concorrentes.

Em suma, Chiavenato (2004), resume os aspectos básicos da teoria da contingência da seguinte maneira:

- Relativismo da administração. A prática da administração deve ser situacional e, consequentemente, adaptável a mudanças no ambiente externo de negócio e a novas tecnologias. Como consequência, gestores devem não só indicar o que fazer, mas constantemente questionar por que fazer.

- Ênfase no ambiente. As empresas são sistemas abertos, isto é, elas devem ser entendidas como mecanismos permeáveis, que mantêm diversas transações com o ambiente e que, por isso, também são influenciadas por ele. Além disso, as características organizacionais das empresas interagem entre si e com o ambiente, provocando alterações nelas de natureza estratégica e organizacional.

- Ênfase na tecnologia. Tanto quanto o ambiente, a tecnologia utilizada pela organização também afeta a estratégia e a estrutura organizacional das empresas. Como mencionado anteriormente, no contexto desta dissertação, o termo tecnologia deve ser entendido em seu sentido mais amplo, que engloba todo o conjunto de conhecimentos empregados na produção de produto ou prestação de serviço.

- Compatibilidade de aspectos das teorias neoclássica e da contingência, possibilitando a necessária convivência das duas abordagens administrativas. A administração por resultados é mais adequada para lidar com aspectos mais internos da empresa, vinculados diretamente a produção de produtos ou 
prestação de serviços, enquanto a teoria da contingência é mais adequada para lidar com aspectos mais externos, que possuem ligação com o ambiente externo.

- Caráter eclético e integrativo. De acordo com a teoria contingencial, não há um único método administrativo ideal para todas as situações, mas um uma variedade de métodos que, a partir de um diagnóstico do ambiente, da tecnologia e das características organizacionais requeridas, devem ser escolhidos e adotados.

Em suma, a forma de encarar a estratégia que foi descrita, essencialmente, utilizando a abordagem de Porter (1989; 1996) é denominada lógica baseada em atividades. Nela, as empresas obtêm vantagem competitiva graças à busca para encontrar um posicionamento estratégico único e valioso em sua indústria, que deverá ser sustentado por uma busca contínua por eficácia operacional. Ou seja, o posicionamento estratégico é resultante da seleção e execução de um conjunto de atividades adequadas estrategicamente para gerar produtos ou serviços de valor superior ao dos rivais (OVIEDO HAITO, 2015).

\subsubsection{O processo de planejamento estratégico em mercados imprevisíveis, modeláveis e competitivos utilizando os Quadro de Modelo de Negócio (Business Model Canvas)}

Atualmente, a tecnologia tem provocado mudanças e transformações cada vez mais rápidas e intensas nas empresas de qualquer indústria. Para Chiavenato (2004), é a descontinuidade que provoca mais instabilidade na administração e na estratégia das empresas. Nas palavras do autor, a descontinuidade "significa que as mudanças não são mais lineares ou sequenciais e nem seguem relação causal (causa e efeito)". Ou seja, planejar o futuro por meio de uma simples projeção do passado não funciona da mesma forma que antes, pois o advento de novas tecnologias, por exemplo, podem fazer com que o passado não mais se assemelhe ao futuro.

Tal constatação, a de que a descontinuidade das transformações na era da informação impacta a maneira de se definir a estratégia, pode ser verificada anteriormente: dependendo do ambiente externo de negócio (mais ou menos previsível e mais ou menos modelável).

Para Chiavenato (2004), o advento da Internet criou uma nova onda de transformações que vem rompendo o equilíbrio econômico de diversos mercados por meio de inovações tecnológicas. Tais inovações, no entanto, se distinguem das praticadas até então porque em vez de procurarem otimizar o que já existe, em alguns mercados, as empresas têm conseguido influenciar demanda e condições de concorrência por meio da oferta de novos produtos e serviços o que, eventualmente, provoca a destruição de empresas velhas e de antigos modelos 
de negócio, num fenômeno denominado por Schumpeter (1947) de destruição criativa (Figura 12).

Para Chiavenato (2004), essa nova onda de transformações foi provocada, principalmente, pelo advento da Internet, que facilitou enormemente a comunicação e o acesso a informação, uma consequência do avanço das tecnologias da informação que, segundo Kanter (1996), conferiu mobilidade aos principais componentes de uma empresa: capital, pessoas e ideias, simultaneidade no lançamento de determinados produtos ou serviços em todas as partes do mundo e aumento da disponibilidade de produtos ou serviços alternativos para os clientes.

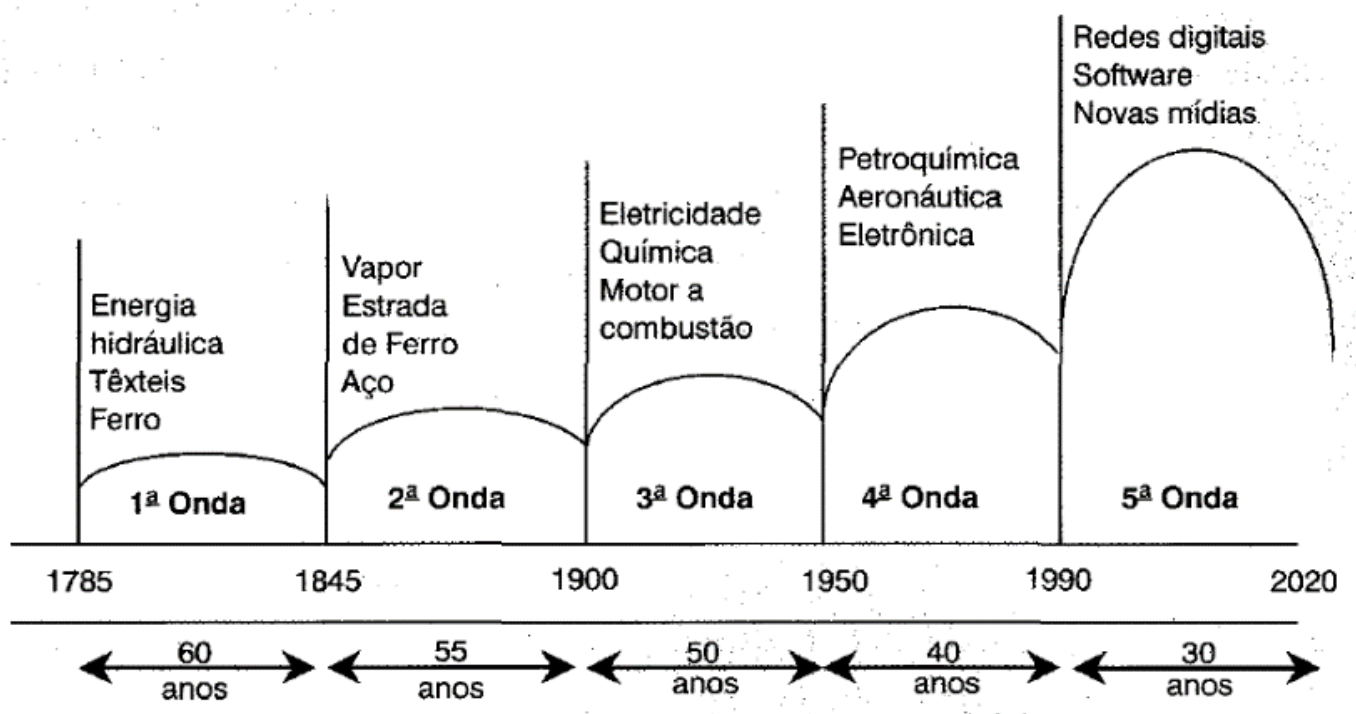

Figura 12 - As ondas de transformações de Schumpeter (CHIAVENATO, 2004)

Desta forma, é possível apontar os elementos da quinta onda de transformações, isto é, a Internet, como uma das causadoras do aumento da maleabilidade de alguns ambientes externos de negócio, conceito de Reeves, Love e Tillmanns (2012): quanto maior a frequência de destruições criativas neles, mais moldáveis eles tendem a ser, ou seja, mais algumas características do mercado, como demanda e condições de competição, podem ser influenciadas por empresas inovadoras.

Ao analisar o mercado em que atuam as EES, Oviedo Haito (2010) o descreve como desfavorável do ponto de vista das condições de competição impostas pelos contratantes e como desleais do ponto de vista da concorrência.

Em mercados como esses, imprevisíveis, modeláveis e competitivos, Chiavenato (2004) ressalta a importância que ainda maior da estratégia para que empresas consigam atingir seus objetivos organizacionais. Shafer, Smith e Linder (2005) afirmam que a probabilidade do 
sucesso a longo prazo aumenta conforme o rigor e a formalidade que uma empresa testa sistematicamente as diretrizes definidas em sua estratégia.

Autores, como McGrath (2010), contestam a lógica baseada em atividades, como a de Porter (1996), descrita no item anterior. Para ela, lógicas como essa não são capazes de oferecer aos gestores a flexibilidade de atuação necessária para ambientes de incerta e alta imprevisibilidade. Nessa lógica, uma vez definido o posicionamento estratégico, mudanças exigem alterações complexas tanto nas próprias atividades, quanto na adequação estratégica entre elas.

Recentemente, o conceito de modelo de negócio foi incorporado ao processo de planejamento estratégico das empresas. Este modelo é particularmente útil para aquelas inseridas em ambientes de incerteza e imprevisibilidade, pois é ainda mais modelável que o modelo da teoria da contingência, ou seja, o processo de planejamento estratégico utilizando modelos de negócio permite elaborar a estratégia e alterá-la com maior facilidade.

Um modelo de negócio deverá refletir as escolhas originárias do processo de planejamento estratégico, explicitando suas implicações operacionais e facilitando a análise, o teste e a validação das premissas adotadas inicialmente. Para Magretta (2002), Chesbrough (2007) e Zott e Amit, (2007), o processo de planejamento estratégico utilizando o modelo de negócio oferece um método de analisar empresas que é superior aos conceitos tradicionais como o posicionamento estratégico que ela ocupa dentro de uma indústria.

Para McGrath (2010), o conceito é interessante porque sugere uma mudança na maneira em que a estratégia é concebida, criada e executada. Ambientes de alta incerteza, complexidade e de rápidas mudanças, estratégias dependem de insights, experimentação rápida e aprendizado evolutivo.

Muitas são as definições do termo modelo de negócio. Segundo Macgrath (2010), o conceito pauta-se em quatro pontos que ou são novos ou não eram considerados de maneira substancial nos processos de planejamento estratégico tradicional. Segundo a autora, a perspectiva considerada durante a formulação de um modelo de negócio considera mais as influências de fora para dentro do que as influências de dentro para fora. Isso quer dizer que em vez do foco da empresa ser aprimorar as atividades que executa ou recursos e competências que possui para, com isso, encontrar oportunidades de mercado para utilizá-las, o modelo de negócio induz a empresa a buscar compreender e satisfazer as necessidades dos clientes, exigindo que ela incessantemente tenha que se adaptar.

Para Shafer, Smith e Linder (2005), um modelo de negócio consiste na representação da lógica de funcionamento de uma empresa, que deverá criar e capturar valor ofertando 
produtos ou serviços utilizando uma rede de valor (value network). Essa representação é resultante de um conjunto de escolhas. Para os autores, a definição do modelo de negócio requer a definição de quatro aspectos da empresa: a lógica de funcionamento de sua principal atividade (core logic), as escolhas que foram feitas (em geral, são relações de causa e consequência), a descrição de como ela irá criar e capturar valor (conceito importado de Porter, 1979) e a descrição de sua rede de valor (value network).

Nesta dissertação, o conceito de modelo de negócio adotado é o de Shafer, Smith e Linder (2005): uma representação da lógica de funcionamento de uma empresa.

Para Chesbrough (2010), um modelo de negócio deve articular a proposta de valor, isto é, o valor criado pela oferta de produto ou serviço ao cliente; identificar o mercado e especificar o mecanismo de geração de valor; definir uma estrutura da cadeia de valor requerida para criar e distribuir a oferta e os ativos complementares necessários para sustentar o posicionamento estratégico de uma empresa em seu mercado; detalhar o mecanismo de receita por meio do qual a empresa será paga pela oferta de produto ou serviço que faz; estimar a estrutura de custo e o potencial de lucro, dadas a proposta de valor e a estrutura da cadeia de valor; descrever a posição da empresa dentro de sua cadeia de valor, conectando fornecedores e clientes, incluindo a identificação de possíveis ativos complementares à sua oferta e seus competidores); e, finalmente, formular a estratégia por meio da qual a empresa irá obter e sustentar vantagem competitiva sobre as rivais.

Para Casadesus-Masanell e Ricart (2010), o objetivo da estratégia é escolher o modelo de negócio mais adequado para o posicionamento estratégico escolhido pela empresa para atender a um determinado segmento de clientes. Os autores dividem o processo de planejamento estratégico em duas etapas: a etapa estratégica (strategy stage) e a etapa tática (tactics stage). Na primeira, são elaborados diversos modelos de negócio com base em diferentes diretrizes, visando ao atingimento de um objetivo organizacional em cenários futuros. Os modelos de negócio são, então, comparados e a opção por um é realizada. Em seguida, na segunda etapa, as definições em nível institucional (âmbito da direção e da presidência) terminaram e as diretrizes definidas no modelo de negócio poderão nortear a definição das metas, definições necessárias no nível intermediário da estrutura hierárquica das empresas (âmbito da gerência), facilitando a comunicação e a comunicação da estratégia por todos os níveis. As Figuras 13 e 14 ilustram este esquema de funcionamento. 
Etapa Estratégica

Etapa 1

Empresa escolhe o

Modelo de Negócio

que pretende executar

a fim de competir no

mercado escolhido
Etapa Tática

Etapa 2

São feitas escolhas

táticas dependendo

do Modelo de

Negócio escolhido

na Etapa 1

Figura 13 - Etapas estratégica e tática do processo de planejamento estratégico utilizando o modelo de negócio proposto por Casadesus-Masanell e Ricart (adaptado de CASADESUS-MASANELL e RICART, 2010).

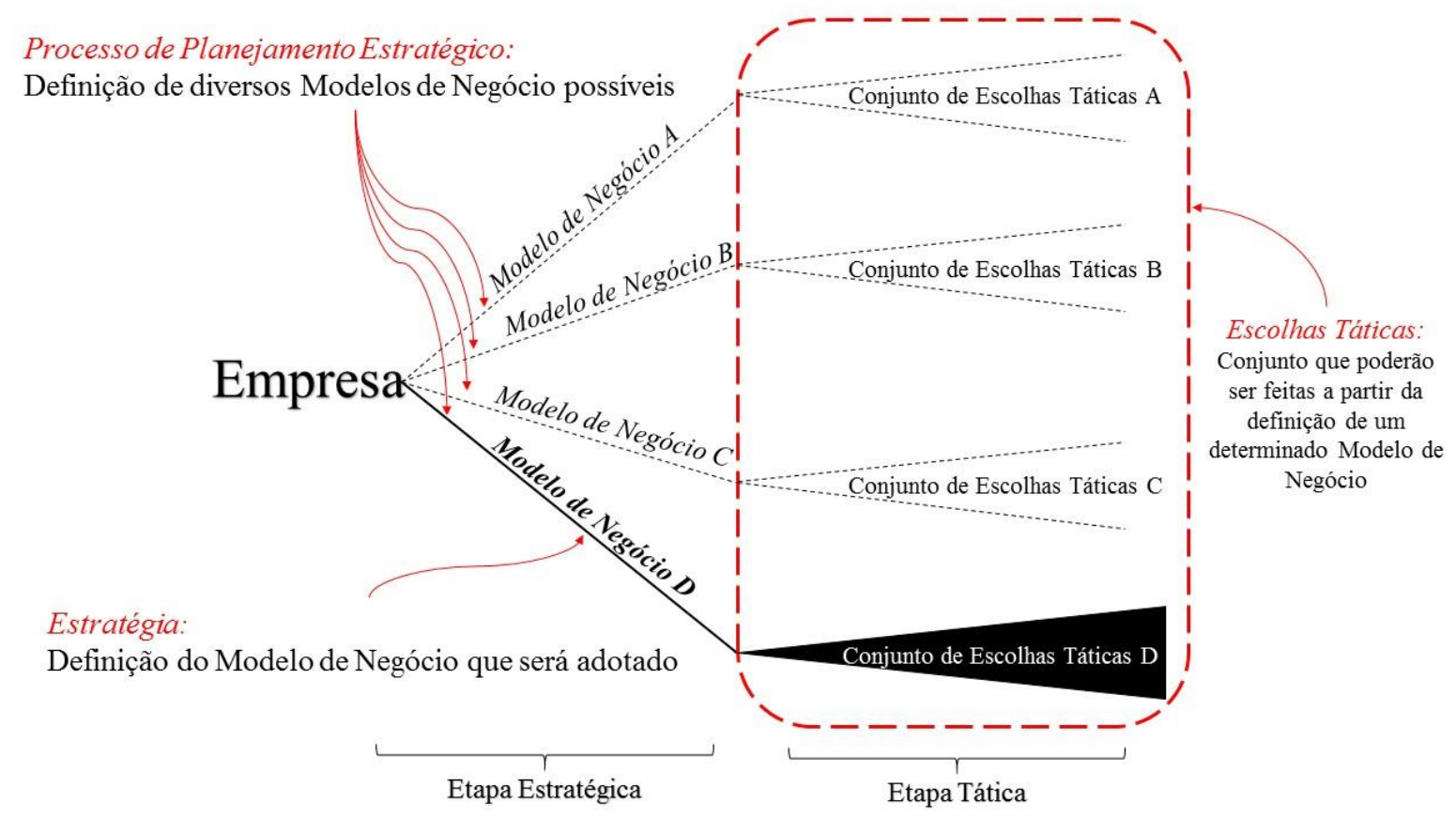

Figura 14 - O processo de planejamento estratégico utilizando o conceito de modelo de negócio proposto por

Casadesus-Masanell e Ricart (adaptado de CASADESUS-MASANELL e RICART, 2010).

Para Osterwalder e Pigneur (2011), um modelo de negócio descreve a lógica de criação, entrega e captura de valor por parte de uma empresa. Trata-se de um esquema para a estratégia ser implementada através das estruturas organizacionais dos processos e sistemas.

Estes autores propuseram uma forma de representação gráfica do modelo de negócio bastante difundida atualmente: o Quadro de Modelo de Negócio, mostrado na Figura 15. Tratase de uma ferramenta gráfica de planejamento estratégico que consiste em um painel com nove componentes necessários ao funcionamento de uma empresa: proposta de valor, segmento de clientes, canais, relacionamento com clientes, fontes de receita, parcerias-chave, atividades- 
chave, recursos-chave e estrutura de custos. O Quadro 1 exemplifica as características de cada componente.

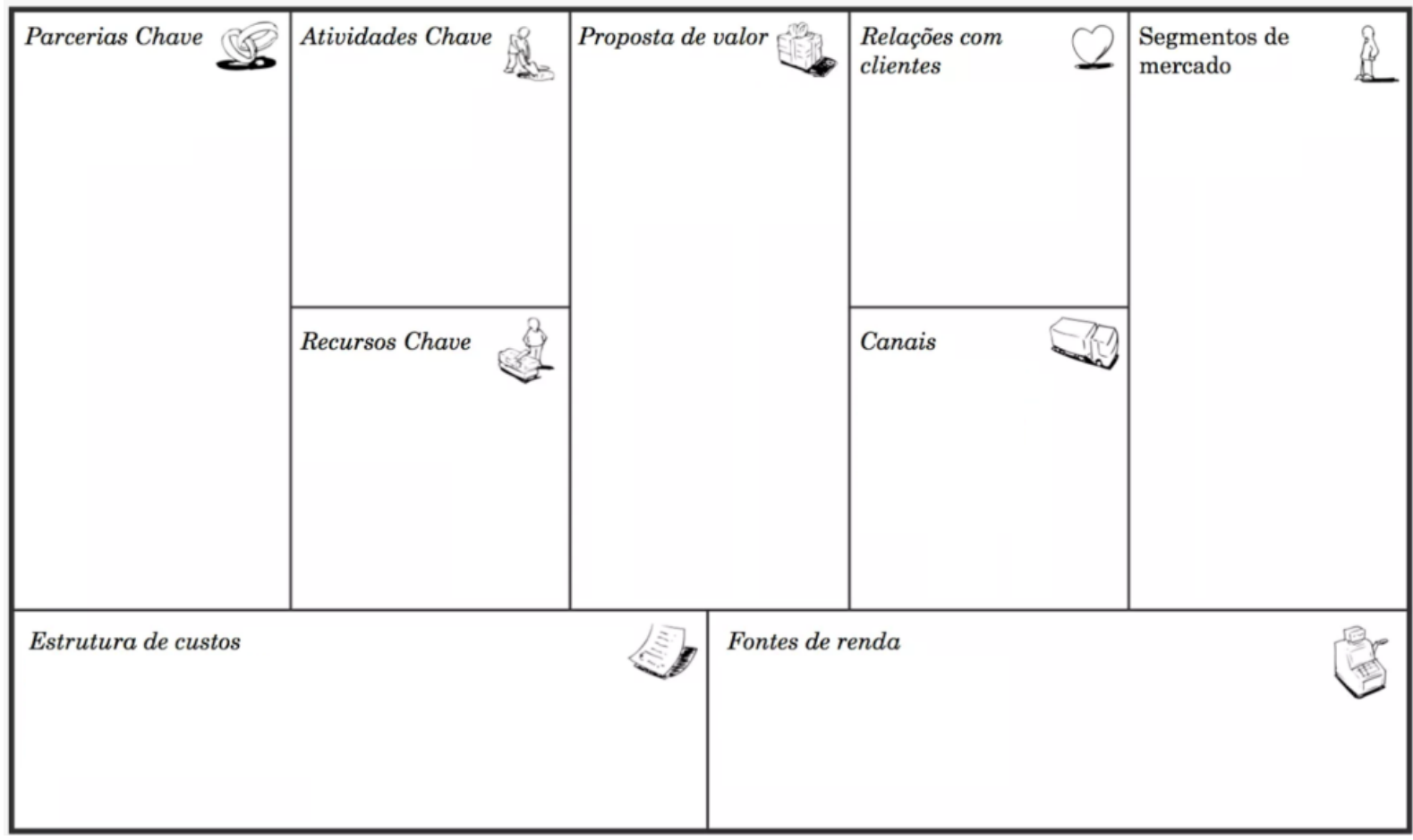

Figura 15 - O Quadro de Modelo de Negócio (Business Model Canvas)

(OSTERWALDER e PIGNEUR, 2010)

Quadro 1 - Componentes do Quadro de Modelo de Negócio (Business Model Canvas) (OSTERWALDER e PIGNEUR, 2010).

\begin{tabular}{l|l|}
$\begin{array}{l}\text { Componente do Quadro } \\
\text { de Modelo de Negócio }\end{array}$ & \multicolumn{1}{c|}{ Características } \\
\hline Segmento de clientes & $\begin{array}{l}\text { Descreve os diferentes grupos de pessoas ou de empresas cujas } \\
\text { necessidades uma empresa busca satisfazer. Exemplos: } \\
\text { determinado mercado de massa ou determinado nicho de } \\
\text { mercado. }\end{array}$ \\
\hline Proposta de valor & $\begin{array}{l}\text { Descreve aquilo que a empresa irá oferecer ao segmento de } \\
\text { clientes, como a produção de um produto ou a prestação de um } \\
\text { serviço. Contribuem para a criação de valor de um produto ou } \\
\text { serviço: novidade, desempenho, personalização, design, marca, } \\
\text { status, preço, redução de custo, redução de risco, acessibilidade } \\
\text { e conveniência. }\end{array}$ \\
\hline Canais & $\begin{array}{l}\text { Descreve como a empresa se comunica e alcança seus } \\
\text { segmentos de clientes para entregar sua proposta de valor. } \\
\text { Trata-se dos pontos de contato dos clientes. Exemplos: site, loja } \\
\text { física, etc. }\end{array}$ \\
\hline $\begin{array}{l}\text { Relacionamento } \\
\text { clientes }\end{array}$ & $\begin{array}{l}\text { Descreve os tipos de relação que uma empresa estabelece com } \\
\text { cada um de seus segmentos de clientes. Exemplos: assistência } \\
\text { pessoal, self-service, etc. }\end{array}$ \\
\hline
\end{tabular}




\begin{tabular}{|l|l|}
\hline \multirow{5}{*}{ Fontes de receita } & $\begin{array}{l}\text { Descreve quanto, como e pelo que cada um dos segmentos de } \\
\text { clientes paga pela proposta de valor que ele recebe. Exemplos: } \\
\text { precificação fixa, isto é, cujos preços são predefinidos baseados } \\
\text { em variáveis estáticas e precificação dinâmica, em que os } \\
\text { preços mudam com base nas condições de mercado. }\end{array}$ \\
\hline $\begin{array}{l}\text { Descreve os recursos mais importantes exigidos para fazer o } \\
\text { modelo de negócio da empresa funcionar. Eles podem ser } \\
\text { físicos, financeiros, intelectuais e humano. Exemplos: recursos } \\
\text { físicos (fábricas, veículos, equipamentos, etc.), intelectuais } \\
\text { (marcas, conhecimentos particulares, patentes, etc.), humano } \\
\text { (uma equipe hábil, por exemplo) e financeiro (como linhas de } \\
\text { crédito que podem servir como garantia financeira do modelo } \\
\text { de negócio). }\end{array}$ \\
\hline $\begin{array}{l}\text { Descreve as ações mais importantes que a empresa deve } \\
\text { realizar para fazer o modelo de negócio funcionar. Exemplos: } \\
\text { atividades de produção (desenvolvimento, fabricação e entrega } \\
\text { de produtos), resolução de problemas (atividade relacionada à } \\
\text { prestação de serviços) e plataforma ou rede (atividades } \\
\text { relacionadas com o gerenciamento de serviços em plataformas } \\
\text { online) }\end{array}$ \\
\hline $\begin{array}{l}\text { Descreve a rede de fornecedores e os parceiros que auxiliam no } \\
\text { funcionamento do modelo de negócio. Exemplos: alianças } \\
\text { estratégicas com fornecedores ou com outras empresas não- } \\
\text { competidoras, joint-ventures entre empresas, etc. }\end{array}$ \\
\hline $\begin{array}{l}\text { Descreve os custos mais importantes para o funcionamento do } \\
\text { modelo de negócio. Estruturas de custo podem ter as seguintes } \\
\text { características: custos fixos (aqueles que não variam apesar do } \\
\text { volume de produtos ou serviços produzidos), custos variáveis } \\
\text { (aqueles que dependem do volume de produto ou serviço } \\
\text { produzido), economias de escala (vantagens de custo obtidas a } \\
\text { partir de alta demanda, onde o custo médio por unidade é } \\
\text { reduzido) e economias de escopo (vantagens de custo obtidas } \\
\text { pelo aproveitamento de componentes do modelo de negócio em } \\
\text { um maior escopo de operações). }\end{array}$ \\
\hline Parcerias-chave
\end{tabular}

O modelo de negócio é planejado ao longo do preenchimento de cada elemento do Quadro de Modelo de Negócio que, sempre que possível, deve se basear em relações de causa e consequência. A partir da definição da proposta de valor, deve-se definir os segmentos de clientes que ela irá atender, a forma de se relacionar com ele, os canais de entrega de tal proposta de valor e uma estimativa financeira esperada das fontes de receita identificadas. Em seguida, deve-se planejar a parte da esquerda do quadro: as parcerias-chave, as atividades-chave e os recursos-chave necessários à elaboração da proposta de valor e de sua entrega a cada segmento de clientes. Por fim, constrói-se uma estimativa financeira da estrutura de custos necessária para isso, comparando-a com a estimativa financeira esperada pelas fontes de receita. Com isso, é possível avaliar a solidez do modelo de negócio, comunicando visualmente a todos os 
interessados as premissas utilizas na definição de cada elemento do modelo de negócio, bem como as relações entre cada um deles.

A Figura 16 representa o processo de planejamento estratégico utilizando o Quadro de Modelo de Negócio. Nele, nota-se que é uma ferramenta para construção de cenários que deve ser encarada como mutável e evolutiva.

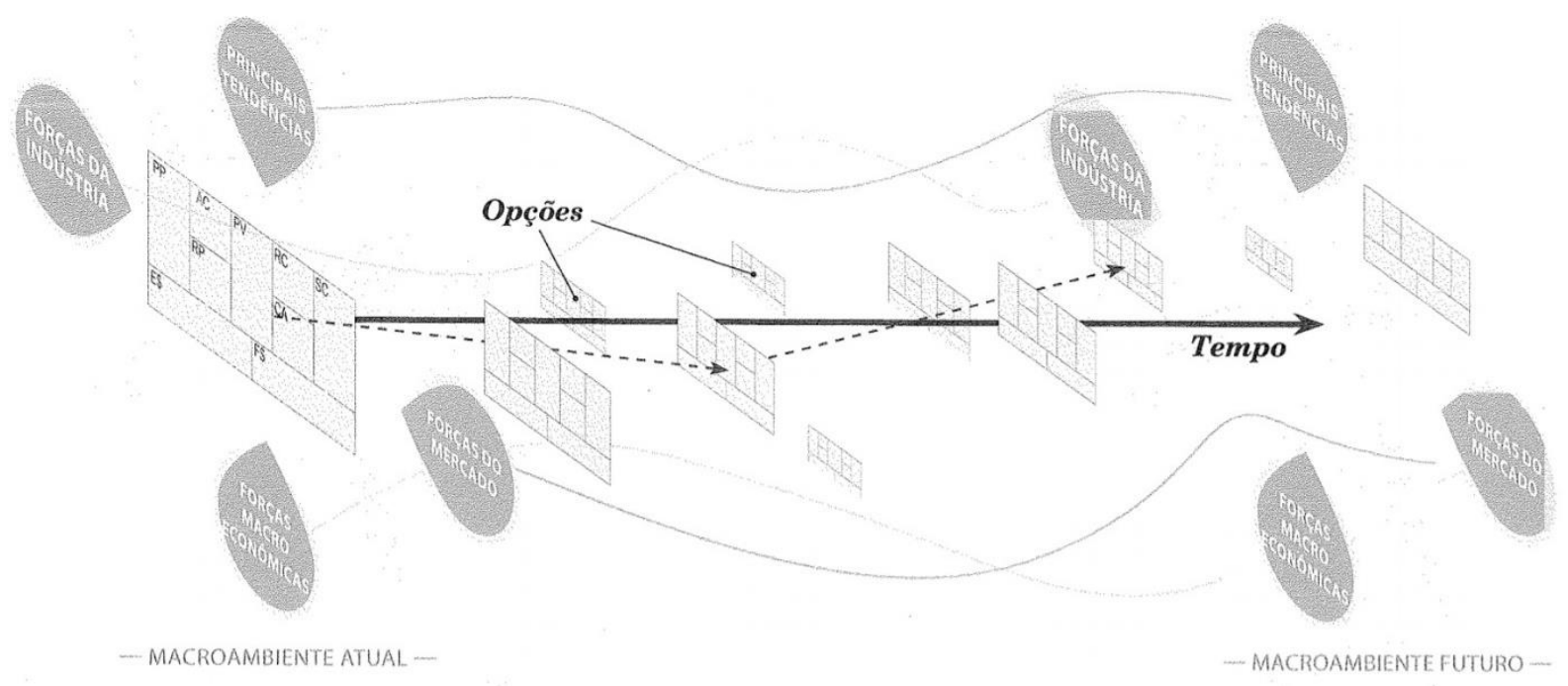

Figura 16 - Alterações e evolução do modelo de negócio utilizando o Quadro de Modelo de Negócio (OSTERWALDER e PIGNEUR, 2010)

Diferentemente da forma tradicional de fazer o planejamento estratégico, pautada na documentação densa e imutável, o conceito de modelo de negócio auxilia a avaliar o quão factível e mensurável podem ser as diretrizes adotadas, por exemplo, no desenvolvimento de novos negócios. Isso graças a uma abordagem mais prática, que envolve experimentação, prototipagem e um senso de trabalho nunca completamente terminado, que requer constante revisão (MCGRATH, 2010).

Outro aspecto importante sobre a adoção dos modelos de negócio no processo de planejamento estratégico de empresas é o fato de que sua formulação não requer conhecimento prévio de todos os elementos que o compõem, forçando uma busca constante pelo aprendizado necessário para completá-lo por meio da experimentação e descoberta.

Desta forma, o Quadro de Modelo de Negócio constitui uma ferramenta singular para a estratégia por dois motivos: ao explicitá-la visualmente, Osterwalder e Pigneur (2012) facilitaram a compreensão sistêmica da empresa por meio de uma análise simples de coerência e da capacidade de mensurar aquilo que foi preenchido em cada uma de suas nove áreas e, ao transmitir a impressão de nunca estar completamente terminado, ele fomenta o aprendizado, a 
experimentação e a descoberta de novos modelos de negócio, uma das formas de inovação mais importantes para empresas imersas em ambientes externos imprevisíveis, modeláveis e competitivos.

Estratégia e inovação acabam, muitas vezes, se confundindo no processo de planejamento estratégico. Segundo Casadesus-Masanell e Ricart (2010), a modelagem e experimentação do modelo de negócio nada mais é do que a estratégia sendo, de fato, realizada. O item seguinte abordará uma das formas de se organizar uma empresa a fim de estabelecer o mínimo de organização necessário à administração e, consequentemente, à definição de uma estratégia.

\subsection{Características básicas da estrutura organizacional de uma empresa}

Como mencionado anteriormente, as empresas são organizações constituídas por pessoas e por de recursos não humanos que, por meio da realização de atividades com o intuito de produzir produtos ou prestar serviços, visam a obter lucro. A condução racional dessas atividades requer administração e a administração requer um mecanismo, em geral, estratificado de pessoas.

Este mecanismo estratificado contém diferentes níveis hierárquicos: institucional ou estratégico, intermediário, gerencial ou tático e operacional (CHIAVENATO, 2004). Pela Figura 17, nota-se que os funcionários e operários fazem parte não fazem parte da administração, mas da operação. São eles os responsáveis diretos pela realização das atividades necessárias à produção de produtos ou à prestação de serviços das empresas.

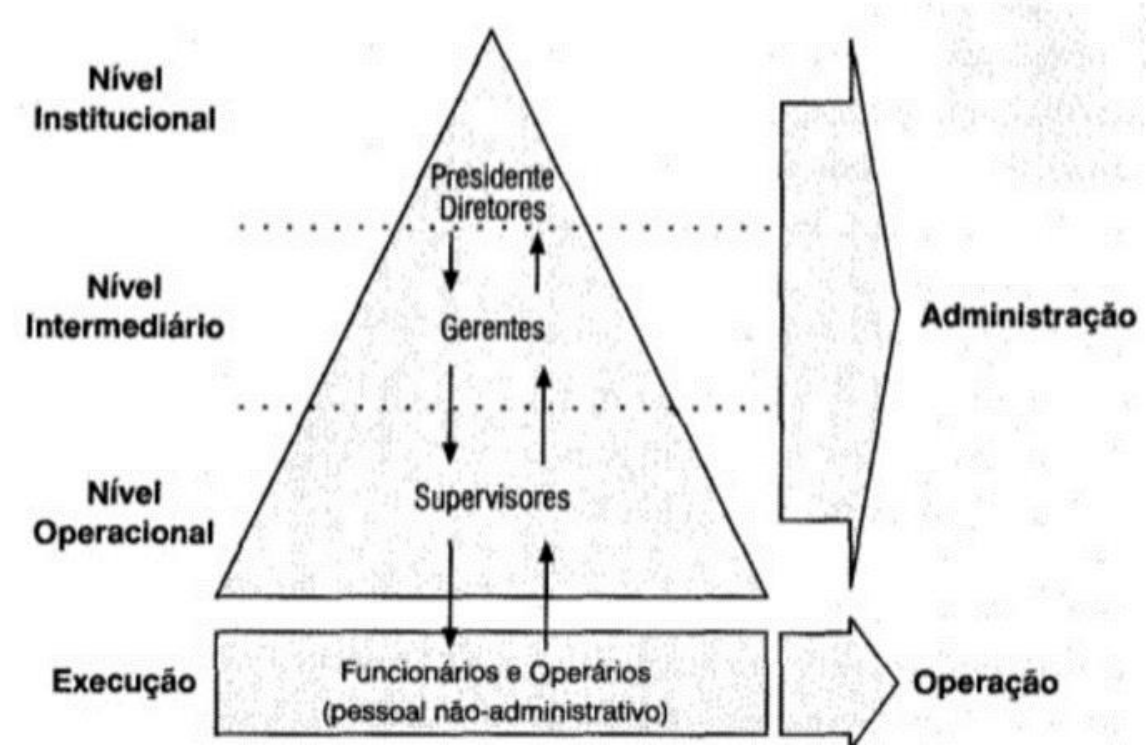

Figura 17 - Níveis hierárquicos estratificados, segundo a teoria neoclássica da administração (CHIAVENATO, 2004) 
Cada nível hierárquico possui uma gama de tarefas administrativas voltadas ao apoio dos funcionários e operários que fazem parte da operação (Figuras 18 e 19). O contexto de atuação também é diferente e a imprevisibilidade e as incertezas são crescentes: menores no nível operacional pois, teoricamente, os supervisores possuem metas e programas cotidianos bem estabelecidos para serem cumpridos; medianos no nível intermediário, pois os gerentes devem amortecê-las para que não afetam a rotina da operação; e maiores no nível institucional, pois a diretoria e a presidência necessariamente assumem riscos ao tomar decisões que afetem o modelo de negócio da empresa inteira.

\begin{tabular}{|c|c|c|c|c|c|}
\hline $\begin{array}{c}\text { Subsistema } \\
\text { Organizacional }\end{array}$ & $\begin{array}{c}\text { Principal } \\
\text { Tarefa } \\
\text { Adminis- } \\
\text { trativa }\end{array}$ & Contexto & $\begin{array}{l}\text { Comporta } \\
\text { mento }\end{array}$ & $\begin{array}{l}\text { Preocu- } \\
\text { pacáa } \\
\text { Básica }\end{array}$ & Lógica \\
\hline $\begin{array}{l}\text { Nivel } \\
\text { Institucional }\end{array}$ & $\begin{array}{c}\text { Relacionar } \\
\text { a empresa } \\
\text { com o } \\
\text { ambiente }\end{array}$ & $\begin{array}{l}\text { Imprevisi- } \\
\text { bilidade e } \\
\text { incerteza }\end{array}$ & $\begin{array}{l}\text { Extro- } \\
\text { versivo }\end{array}$ & Eficácia & $\begin{array}{l}\text { Sistema } \\
\text { Aberto }\end{array}$ \\
\hline $\begin{array}{c}\text { Nível } \\
\text { Intermodiario }\end{array}$ & $\begin{array}{l}\text { Integrar e } \\
\text { coordenar } \\
\text { atividades } \\
\text { internas }\end{array}$ & $\begin{array}{l}\text { Amorteci- } \\
\text { mento da } \\
\text { incerteza }\end{array}$ & $\begin{array}{c}\text { Elo } \\
\text { de } \\
\text { ligaçäo }\end{array}$ & $\begin{array}{l}\text { Inte- } \\
\text { gracalo }\end{array}$ & Bifocal \\
\hline $\begin{array}{c}\text { Nivel } \\
\text { Operacional }\end{array}$ & $\begin{array}{l}\text { Cumprir } \\
\text { as metas e } \\
\text { programas } \\
\text { cotidianos }\end{array}$ & $\begin{array}{l}\text { Previsibi- } \\
\text { lidade } \theta \\
\text { certeza }\end{array}$ & $\begin{array}{l}\text { Intro- } \\
\text { versivo }\end{array}$ & Eficiência & $\begin{array}{l}\text { Sisterna } \\
\text { Fechado }\end{array}$ \\
\hline
\end{tabular}

Figura 18 - Diferenças de tarefas administrativas, contexto, comportamento, preocupação básica e lógica de cada subsistema organizacional (CHIAVENATO, 2004)

\begin{tabular}{|c|c|c|c|c|c|}
\hline $\begin{array}{l}\text { Subsistoma } \\
\text { Organizacional }\end{array}$ & $\begin{array}{c}\text { Visāo } \\
\text { Predomi- } \\
\text { nante }\end{array}$ & Perspectiva & $\begin{array}{l}\text { Ponto de } \\
\text { Vista }\end{array}$ & $\begin{array}{c}\text { Processos } \\
\text { Gerais }\end{array}$ & Decisâo \\
\hline $\begin{array}{l}\text { Nivel } \\
\text { Institucional }\end{array}$ & $\begin{array}{l}\text { Longo } \\
\text { Prazo }\end{array}$ & $\begin{array}{c}\text { Futuro e } \\
\text { destino da } \\
\text { organizaçăo }\end{array}$ & $\begin{array}{l}\text { Satisfa } \\
\text { tório }\end{array}$ & $\begin{array}{l}\text { Não } \\
\text { Progra- } \\
\text { mados }\end{array}$ & $\begin{array}{l}\text { Julga- } \\
\text { mental }\end{array}$ \\
\hline $\begin{array}{c}\text { Nivel } \\
\text { Intermediário }\end{array}$ & $\begin{array}{l}\text { Médio } \\
\text { Prazo }\end{array}$ & $\begin{array}{l}\text { Condiçôes } \\
\text { de presente } \\
\text { e futuro }\end{array}$ & $\begin{array}{l}\text { Neio } \\
\text { termo }\end{array}$ & $\begin{array}{l}\text { Náo Pro } \\
\text { gramados } \\
\text { e progra- } \\
\text { máveis }\end{array}$ & $\begin{array}{l}\text { Meio } \\
\text { termo }\end{array}$ \\
\hline $\begin{array}{c}\text { Nivel } \\
\text { Operacional }\end{array}$ & $\begin{array}{l}\text { Curto } \\
\text { Prazo }\end{array}$ & $\begin{array}{c}\text { Presente } \\
\text { e } 0 \\
\text { cotidiano }\end{array}$ & Otimizante & $\begin{array}{l}\text { Progra- } \\
\text { máveís }\end{array}$ & $\begin{array}{l}\text { Compu- } \\
\text { tacional }\end{array}$ \\
\hline
\end{tabular}

Figura 19 - Diferenças de visão predominante, perspectiva, ponto de vista, processos gerais e características da tomada de decisão de cada subsistema organizacional (CHIAVENATO, 2004) 
Para a teoria neoclássica da administração, há quatro funções sequenciais básicas: planejar, organizar, dirigir e controlar (Figura 20). São denominadas funções administrativas e, juntas, compõem um processo cíclico, dinâmico e interativo chamado processo administrativo, que deve ser desempenhado por supervisores, gerentes, diretores e presidente das empresas (CHIAVENATO, 2004). O planejamento é a primeira função administrativa. Espera-se que empresas não trabalhem por improviso, então, na teoria neoclássica da administração, quase tudo nelas deve ser determinado antecipadamente, isto é, os objetivos a serem atingidos por aquela empresa e a maneira pela qual alcançá-los.

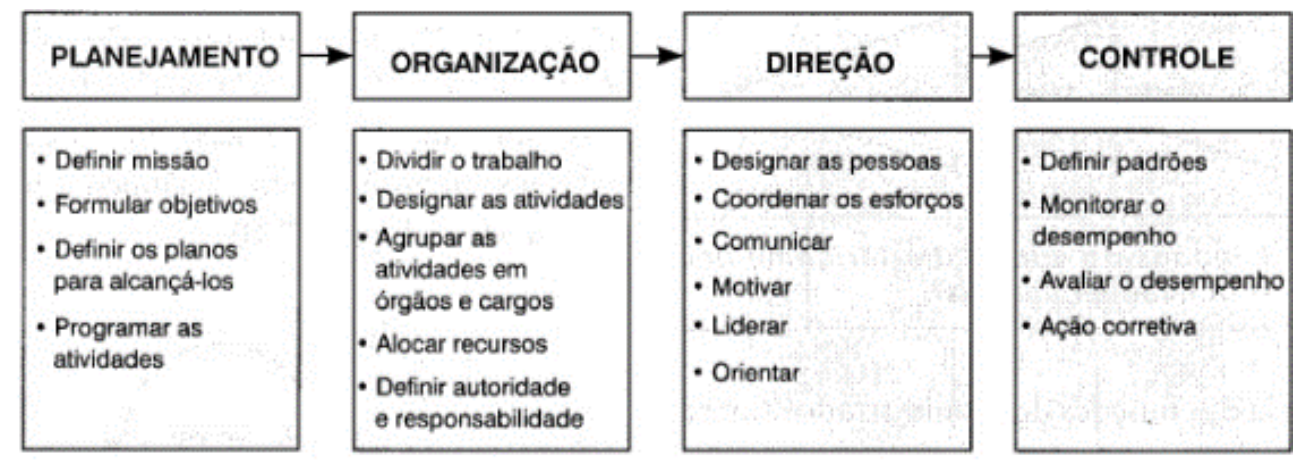

Figura 20 - As funções administrativas organizadas em sequência formando o processo administrativo (CHIAVENATO, 2004)

As diferenças entre as funções administrativas desempenhadas em cada nível hierárquico são mostradas na Figura 21.

\begin{tabular}{|c|c|c|c|c|}
\hline Niveis & Planejamento & Organizaçāo & Direçäo & Controle \\
\hline $\begin{array}{l}\text { Institu- } \\
\text { cional }\end{array}$ & $\begin{array}{l}\text { Estratégico } \\
\text { \& Global. } \\
\text { Objetivos Or- } \\
\text { ganizacionais. }\end{array}$ & $\begin{array}{l}\text { Desenho } \\
\text { Organi- } \\
\text { zacional }\end{array}$ & Direçắo & $\begin{array}{c}\text { Estratégico } \\
\text { e Giobal }\end{array}$ \\
\hline $\begin{array}{l}\text { Interme- } \\
\text { diário }\end{array}$ & $\begin{array}{c}\text { Tático e De- } \\
\text { partamental. } \\
\text { Objetivos } \\
\text { Intermediários. }\end{array}$ & $\begin{array}{l}\text { Desenho } \\
\text { Departa- } \\
\text { mental }\end{array}$ & Gerência & $\begin{array}{c}\text { Tático } \\
e \\
\text { Departamental }\end{array}$ \\
\hline $\begin{array}{l}\text { Opera- } \\
\text { cional }\end{array}$ & $\begin{array}{l}\text { Operacional } \\
\text { e Cotidiano. } \\
\text { Programas } \\
\text { e metas. }\end{array}$ & $\begin{array}{c}\text { Desenho } \\
\text { de Cargos } \\
\text { e de } \\
\text { Tarefias }\end{array}$ & Supenvisão & $\begin{array}{c}\text { Operacional } \\
\text { 9 } \\
\text { Detalhado }\end{array}$ \\
\hline
\end{tabular}

Figura 21 - Diferenças nas formas de planejamento, organização, direção e controle de cada subsistema organizacional (CHIAVENATO, 2004)

Com relação aos objetivos organizacionais das empresas podem ser desdobrados do topo da hierarquia (objetivos organizacionais) à base (normas). Enquanto os objetivos 
organizacionais são amplos, genéricos e poucos, as normas são específicas, detalhadas e numerosas (Figura 22).

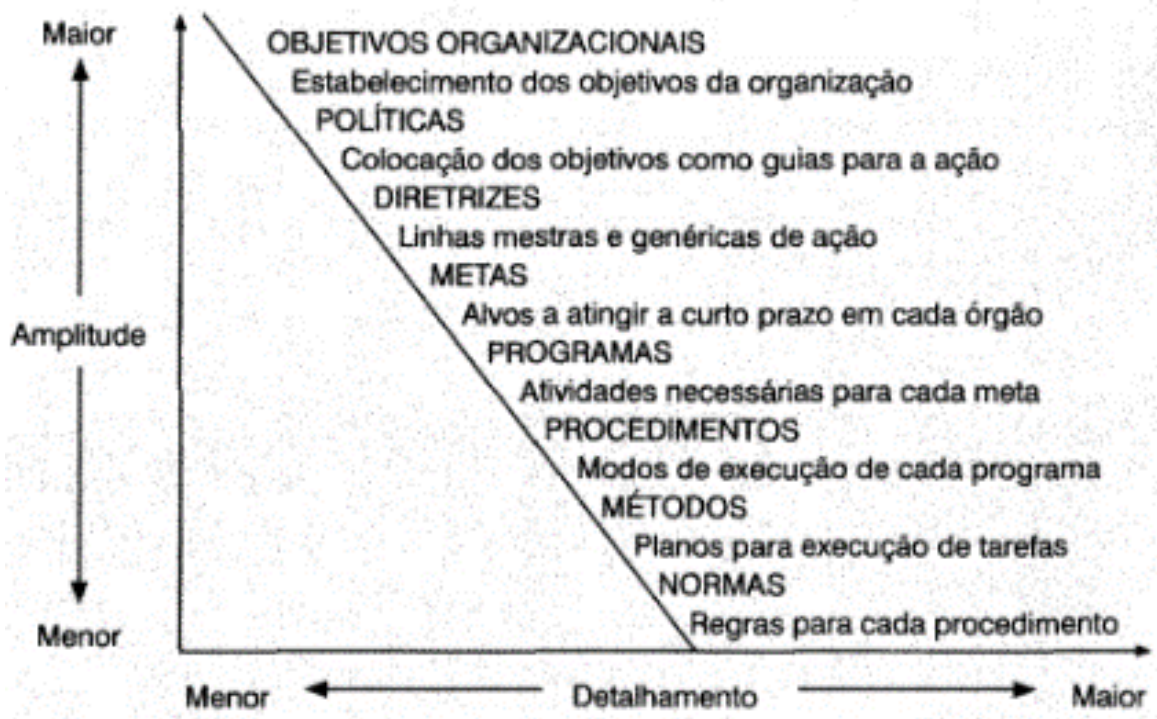

Figura 22 - Os desdobramentos dos objetivos das empresas (CHIAVENATO, 2004)

Assim, uma vez definidos os objetivos organizacionais de uma empresa, as políticas constituem o próximo nível de desdobramento que, nas palavras de Chiavenato (2004), "são afirmações genéricas baseadas nos objetivos organizacionais e que funcionam como guias orientadoras da ação administrativa. Proporcionam marcos ou limitações - embora flexíveis e elásticos - para demarcar as áreas dentro das quais a ação administrativa deverá se desenvolver. São genéricas e utilizam verbos como manter, seguir, usar, prover, assistir, etc. As mais comuns são as políticas de recursos humanos (como tratar os funcionários da organização), as políticas de vendas (como tratar os clientes) e as políticas de preços (como manejar preços diante do mercado)".

Já as diretrizes são um pouco mais específicas que as políticas, mas mais gerais que as metas, que são objetivos mais imediatos, como produção ou faturamento mensal. Para Chiavenato (2004), as diretrizes "são princípios estabelecidos para possibilitar o alcance dos objetivos pretendidos pela organização. Como os objetivos são fins, as diretrizes servem para balizar os meios adequados para atingi-los e canalizar as decisões. Existem diretrizes de pessoal (como recrutar e selecionar candidatos), diretrizes de compras (como fazer seleção de fornecedores, etc. ". Nota-se que Chiavenato (2004) não cita como exemplos diretrizes voltadas à inovação, como aumentar o faturamento ou a produtividade por meio de novos produtos, 
novos serviços, novos processos, novas formas de organização, novos modelos de negócio, entre outros.

Além dos desdobramentos de objetivos, há também, segundo Chiavenato (2004), uma hierarquia de planejamento dividida em três níveis: planejamento estratégico, planejamento tático e planejamento operacional. O planejamento estratégico é o mais amplo e afeta toda a empresa. São características desse nível de planejamento a projeção no longo prazo, o envolvimento de todos os recursos e áreas de atividade da empresa e a definição pela cúpula administrativa, isto é, o nível institucional do qual fazem parte, em geral, presidente e diretores.

Nesta dissertação, o escopo resume-se a discutir aspectos da função administrativa de planejamento no nível estratégico. Pretende-se, também, discutir os objetivos organizacionais das EEE em termos de inovação desdobrando-os até o nível de diretrizes.

\subsubsection{Influência da estratégia na estrutura organizacional das empresas}

A definição da estratégia e as características do ambiente externo de negócio de uma empresa têm influência na determinação de sua estrutura organizacional. Segundo Chiavenato (2004), ambientes diferentes levam as empresas a adotar estratégias diferentes e estas novas estratégias exigem estruturas organizacionais adequadas para serem executadas.

A pesquisa conduzida pelos pesquisadores Burns e Stalker (1961) teve por objetivo identificar a relação entre práticas administrativas e o ambiente externo das empresas manufatureiras inglesas na metade do século XX. Nela, os pesquisadores encontraram duas práticas administrativas diferentes, uma mais adequada a condições estáveis e permanentes do ambiente externo de negócio e, a outra, mais adequada a ambientes instáveis e dinâmicos. Denominaram o primeiro sistema mecanicista e, o segundo, sistema orgânico.

Os sistemas mecanicistas, mais adequados a ambientes externos de negócio estáveis e permanentes, se assemelham a processos de organização fabril, em que as tarefas são claramente definidas e divididas por especialistas, que as executam sem ter noção das demais tarefas da empresa. As lideranças são responsáveis por cuidar do relacionamento entre tarefas e a interação entre gestor e subordinado é vertical, oriunda de uma hierarquia rígida em que o conhecimento está concentrado na cúpula.

Já os sistemas orgânicos, mais adequados a ambientes externos de negócio instáveis e dinâmicos, em que raramente os problemas podem ser facilmente fragmentados e distribuídos entre especialistas de uma hierarquia definida, são adaptáveis. As tarefas são flexíveis em termos de métodos e obrigações e devem ser constantemente redefinidas a partir da interação com as outras pessoas que participam dela. As interações são verticais e horizontais. A premissa 
é a de que o conhecimento está distribuído por toda a empresa, não só concentrada na cúpula. As diferenças entre as características dos sistemas mecânicos e dos sistemas orgânicos foi resumida no Quadro 2.

Quadro 2 - Características dos sistemas mecânicos e orgânicos (adaptado de CHIAVENATO, 2004).

\begin{tabular}{|c|c|c|}
\hline Características & Sistemas Mecânicos & Sistemas Orgânicos \\
\hline Estrutura organizacional & $\begin{array}{l}\text { Burocrática, permanente, } \\
\text { rígida e flexível }\end{array}$ & $\begin{array}{l}\text { Flexível, maleável, } \\
\text { adaptativa e transitória }\end{array}$ \\
\hline Autoridade & $\begin{array}{l}\text { Baseada na hierarquia e no } \\
\text { comando }\end{array}$ & $\begin{array}{l}\text { Baseada no conhecimento e } \\
\text { na consulta }\end{array}$ \\
\hline Processo de decisão & $\begin{array}{l}\text { Decisões centralizadas na } \\
\text { cúpula da organização }\end{array}$ & $\begin{array}{c}\text { Decisões descentralizadas ad } \\
\text { hoc (aqui e agora) }\end{array}$ \\
\hline Comunicação & Quase sempre vertical & Quase sempre horizontal \\
\hline Confiabilidade em: & $\begin{array}{l}\text { Regras e regulamentos } \\
\text { formalizados por escrito e } \\
\text { impostos pela empresa }\end{array}$ & $\begin{array}{c}\text { Pessoas e comunicação } \\
\text { informal }\end{array}$ \\
\hline Ambiente & Estável e permanente & Instável e dinâmico \\
\hline
\end{tabular}

A Figura 23, por sua vez, ilustra os desenhos característicos da estrutura organizacional de empresas que adotam práticas de administração essencialmente mecanicistas e de empresas que adotam práticas de administração essencialmente orgânicas.

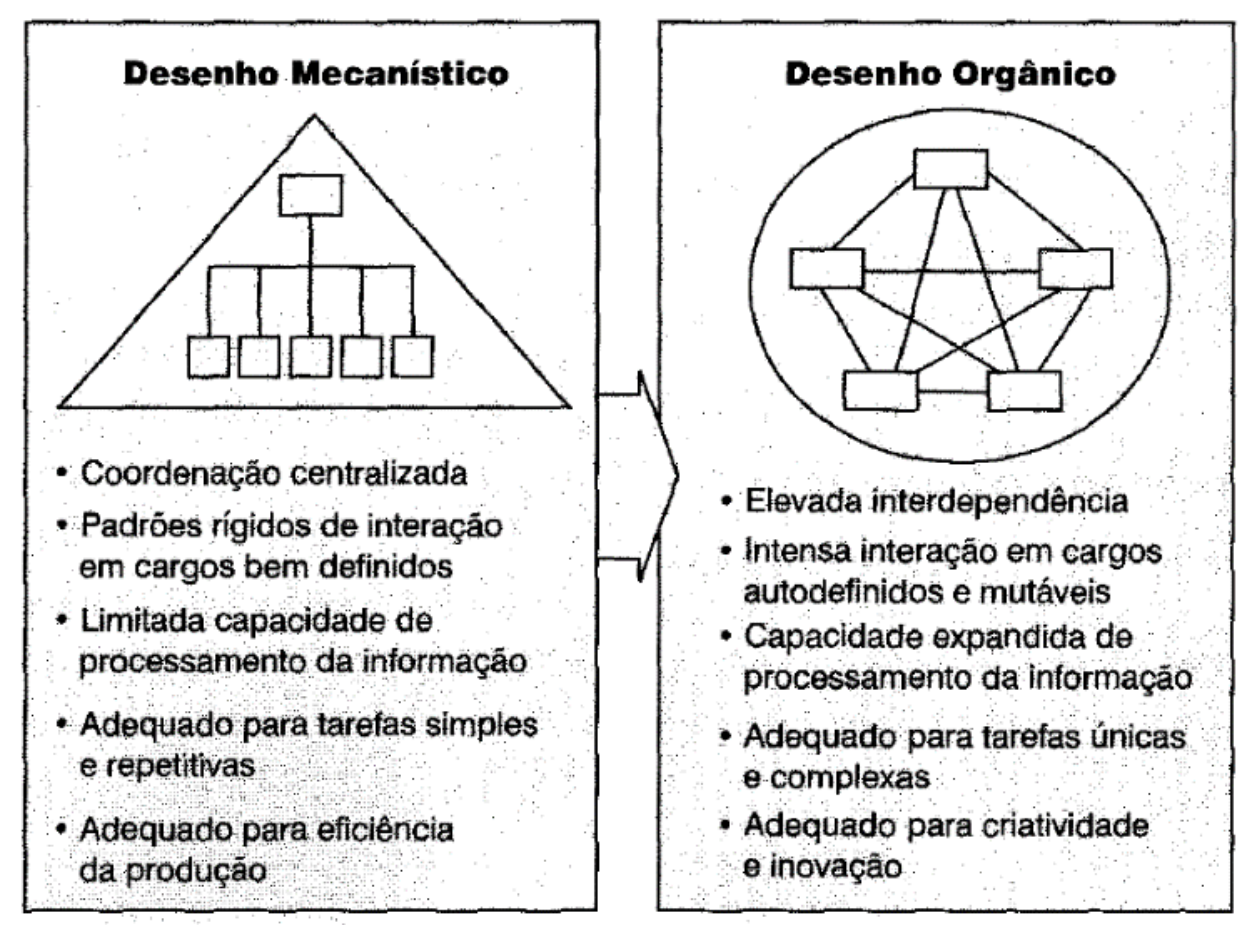

Figura 23 - Propriedades das estruturas organizacionais mecanicistas e orgânicas (CHIAVENATO, 2004). 
A pesquisa de WOODWARD (1970) identifica uma forte correlação entre estrutura organizacional e previsibilidade do sistema de produção de empresas manufatureiras. Segundo o autor, quanto menor a previsibilidade dos resultados, menor a necessidade de se aumentar os níveis hierárquicos da empresa. Outra descoberta é a de que empresas em ambientes estáveis necessitam de estruturas organizacionais diferentes das empresas atuando em ambientes instáveis.

Outros fatores que influenciam a estrutura organizacional de uma empresa são o ambiente em que ela está inserida, sua estratégia, a tecnologia empregada por ela e a prática sistemática de inovação.

\section{A prática da inovação nas empresas}

No contexto desta dissertação, algumas causas encontradas para explicar a queda sistemática da produtividade no mercado de serviços de execução especializada para construção civil foram a commodização acelerada dos serviços prestados pelas empresas, a intensificação da "guerra" de preços e o consequente encolhimento das margens de lucro das empresas que nele atuam. Tais características se assemelham ao ambiente externo de negócio descrito como "mar vermelho" por Kim e Mauborgne (2005), em que as opções de produtos ou serviços são tão semelhantes que a seleção quase sempre se baseia apenas preço.

Quando uma empresa enfrenta queda sistemática na oferta de preços por seus serviços e queda sistemática em suas margens de lucro, seja motivada pelo aumento de custos de produção, seja motivada pela diminuição do faturamento, isto acaba se tornando um problema estratégico relevante que deve ser combatido para preservar sua saúde financeira.

Porter (1996) sugere que, nestes casos, as empresas devem aprofundar seu posicionamento estratégico oferecendo, por exemplo, produtos ou serviços difíceis de serem copiados pela concorrência, adotando estratégias de diferenciação ou de liderança de custos.

Kim e Mauborgne (2005) sugerem a necessidade de um "movimento estratégico" composto por um conjunto de decisões e ações gerenciais que deverão buscar a criação de novos produtos e serviços para atender mercados inexplorados pela concorrência para, desta forma, gerar saltos significativos na demanda.

De qualquer forma, para vencer os desafios de sobrevivência e de crescimento, as empresas devem recorrer à prática sistemática da inovação. Segundo Schumpeter (1947), as empresas inovam em busca de lucro. 
Por exemplo, no caso de uma inovação de processo que eleve a produtividade, a empresa obtém uma vantagem de custo sobre seus concorrentes, pois diminui os custos necessários para produzir seu produto ou para prestar seu serviço. Esta vantagem permite que a empresa obtenha uma margem de lucro maior mesmo se praticar os mesmos preços vigentes de mercado. Ela pode também procurar uma combinação de preço baixo e margem de lucro razoável para conquistar uma participação maior no mercado e, com isso, obter ainda mais lucros.

No caso de inovação de produto, a empresa obtém uma posição monopolista durante o tempo necessário à imitação pelos seus concorrentes. Esta posição monopolista permite que a empresa estabeleça um preço mais elevado do que seria possível em um mercado altamente competitivo.

Essa busca por vantagens em relação à concorrência utilizando a inovação pode ser empreendida de diferentes formas pelas empresas. O Quadro 3, adaptado de Tidd e Bessant (2013), elenca os mecanismos de inovação que elas utilizam e as vantagens decorrentes de seu funcionamento bem-sucedido.

Quadro 3 - Vantagens que podem ser obtidas por meio da inovação (adaptado de TIDD e BESSANT, 2013).

\begin{tabular}{|c|c|}
\hline Mecanismo & Vantagem em relação à concorrência \\
$\begin{array}{c}\text { Novidade na oferta de } \\
\text { produto ou serviço }\end{array}$ & Oferecer algo que ninguém mais consegue \\
Novidade no processo & Oferecer algo de uma forma que os outros não \\
conseguem imitar
\end{tabular}


Uma influência importante sobre as maneiras pelas quais a inovação é inserida na estratégia e gerenciada é, sem dúvida, o tamanho da empresa. No entanto, um dos paradigmas a serem rompidos é o de considerar a inovação como exclusiva às empresas de grande porte. Na verdade, como citado por Tidd e Bessant (2013), a existência de um processo de inovação eficaz não dependo do porte, mas da criação de estruturas e comportamentos que se apliquem à configuração da empresa. Como mostra o Quadro 4, a inovação em empresas de menor porte possui vantagens e desvantagens se comparada à inovação em empresas de maior porte.

Quadro 4 - Vantagens e desvantagens da inovação em empresas de menor porte (TIDD e BESSANT, 2013)

\begin{tabular}{|c|c|}
\hline Vantagens & Desvantagens \\
\hline Velocidade na tomada de decisões & $\begin{array}{l}\text { Falta de sistemas formais para o controle } \\
\text { administrativo, de tempo e custo, por } \\
\text { exemplo, dos projetos de inovação }\end{array}$ \\
\hline Cultura informal & $\begin{array}{l}\text { Falta de acesso a recursos-chave, } \\
\text { especialmente fundos de investimento }\end{array}$ \\
\hline $\begin{array}{l}\text { Comunicação de alta qualidade - todos } \\
\text { sabem o que está acontecendo }\end{array}$ & $\begin{array}{l}\text { Falta de habilidades fundamentais e } \\
\text { experiência }\end{array}$ \\
\hline Visão clara e compartilhada & Falta de estratégia e direção de longo prazo \\
\hline Flexibilidade e agilidade & $\begin{array}{l}\text { Falta de estrutura organizacional e de um } \\
\text { processo de planejamento estratégico }\end{array}$ \\
\hline Espírito empreendedor que assume riscos & Má gestão de riscos \\
\hline $\begin{array}{c}\text { Energia, entusiasmo, paixão pela } \\
\text { inovação }\end{array}$ & $\begin{array}{l}\text { Falta de atenção aos detalhes, falta de } \\
\text { sistemas }\end{array}$ \\
\hline Bons em formar redes internas e externas & Falta de acesso a recursos \\
\hline
\end{tabular}

A inovação é frequentemente a característica mais importante associada ao sucesso de empresas de pequeno e médio porte. De acordo com o Survey of Innovation, pesquisa publicada em 2006 pela agência Statistics Canada, constata que empresas inovadoras normalmente atingem um crescimento maior que aquelas que não inovam e que as empresas que aumentam seus lucros e participação de mercado são justamente aquelas que mais inovam.

Outra publicação que corrobora isso é Endeavor (2015), que analisou dados de empresas brasileiras consideradas de alto crescimento, isto é, cujo faturamento aumentou pelo menos $20 \%$ ao ano nos três anos anteriores aos da pesquisa. Destas, a esmagadora maioria $(92,1 \%)$ era de pequeno (10 a 49 funcionários) ou médio porte (até de 50 a 249 funcionários).

Outro paradigma a ser rompido ao tratar do tema inovação é o de associá-la, exclusivamente, a empresas do setor de alta tecnologia. As oportunidades de inovação mudam com o passar do tempo e é natural que em setores novos, como o de softwares ou o de nanotecnologia, haja uma brecha para a experimentação com novos conceitos sobre produtos e 
serviços. Indústrias mais maduras, como a da construção civil, no entanto, tendem a focar na inovação de processos, procurando por modelos capazes de disponibilizar produtos e serviços de maneira mais econômica e flexível, ou por novos mercados para os quais vendê-los.

Endeavor (2015) mostra que a maior parte destas empresas consideradas de alto crescimento estão dispersas por diversos segmentos, como varejo (20,83\%), construção civil $(13,29 \%)$ e bens de consumo $(9,87 \%)$. Outra informação interessante relevada pelo estudo é a média de idade destas empresas: 14 anos no Brasil.

Além do porte e do setor, outras variáveis do ambiente em que as empresas estão inseridas influenciam na forma como elas inovam. São exemplos a existência de um sistema nacional de inovação, que fomenta parcerias e facilita o acesso das empresas ao conhecimento e aos recursos financeiros necessários a seus projetos de inovação, a maturidade tecnológica da indústria, o grau de novidade desejado para os projetos de inovação que, dependendo de seu ineditismo para a própria empresa, exige estratégias e estruturas organizacionais diferentes e, por fim, os agentes reguladores, capazes de exigir que as empresas se adaptem a determinadas a leis ou normas. O Quadro 5 exibe um resumo das variáveis do ambiente que provocam mudanças na forma das empresas inovar.

Quadro 5 - Como o ambiente afeta a forma de inovar das empresas (adaptado de TIDD e BESSANT, 2013)

\section{Variável do ambiente Modidicações na forma de inovar das empresas}

\begin{tabular}{|l|l|}
\hline Setor & $\begin{array}{l}\text { Setores diferentes possuem prioridades distintas, como o indústria } \\
\text { manufatureira e a indústria da construção }\end{array}$ \\
\hline Porte & $\begin{array}{l}\text { Empresas pequenas diferem em termos de acesso a recursos, etc., e } \\
\text { assim precisam criar mais parcerias }\end{array}$ \\
\hline $\begin{array}{l}\text { Sistemas nacionais de } \\
\text { inovação }\end{array}$ & $\begin{array}{l}\text { Países diferentes possuem contextos mais ou menos propícios em } \\
\text { termos de instituições, políticas, etc. }\end{array}$ \\
\hline $\begin{array}{l}\text { Maturidade } \\
\text { tecnológica } \\
\text { indústria }\end{array}$ & $\begin{array}{l}\text { Indústrias em estágios diferentes enfatizam aspectos distintos de } \\
\text { inovação-por exemplo, novas indústrias tecnológicas vs. empresas } \\
\text { maduras já estabelecidas }\end{array}$ \\
\hline $\begin{array}{l}\text { Grau de novidade } \\
\text { desejado para os } \\
\text { projetos de inovação }\end{array}$ & $\begin{array}{l}\text { Inovação incremental do tipo "mais do mesmo" e inovações } \\
\text { radicais exigem estratégias e estruturas organizacionais diferentes. } \\
\text { No limite, as empresas podem utilizar "organizações ambidestras" } \\
\text { ou mesmo criar outras empresas para explorar as oportunidades } \\
\text { identificadas }\end{array}$ \\
\hline $\begin{array}{l}\text { Papel dos agentes } \\
\text { externos } \\
\text { reguladores como }\end{array}$ & $\begin{array}{l}\text { Alguns setores, como serviços essenciais, telecomunicações, e } \\
\text { alguns serviços públicos, são altamente influenciados por políticas } \\
\text { externas que moldam a intensidade e a direção da atividade } \\
\text { inovadora. Outros, como os de alimentação e saúde, podem ser } \\
\text { altamente regulados em certas direções }\end{array}$ \\
\hline
\end{tabular}


O item a seguir abordará como a prática da inovação tem mudado ao longo dos anos e discutirá alguns dos vários significados que o termo inovação pode ter.

\subsection{As diversas faces da inovação}

Ao longo do tempo, a prática do processo inovação nas empresas passou por pelo menos quatro alterações substanciais. No entanto, quer seja uma empresa integrante da indústria manufatureira, quer seja uma empresa integrante da indústria da construção, a prática da inovação sempre esteve atrelada a áreas de pesquisa e desenvolvimento quando estas existiam. A sequência histórica construída por Blank (2015) descreve bem cada uma das fases da prática da inovação nas empresas.

Entre as décadas de 1870 e 1920, a inovação acontecia fora das grandes empresas, encabeçadas por inventores independentes como Thomas Edison e Alexander Graham Bell, ou por pequenas empresas, cujas patentes eram vendidas. Entre as décadas de 1920 e 1990, as grandes empresas procuraram controlar o processo de desenvolvimento de novos produtos. Para isso, elas trouxeram a inovação para dentro de suas instalações, constituindo laboratórios de pesquisa e desenvolvimento experimental (P\&D). A pesquisa e desenvolvimento experimental ou P\&D compreende, segundo a OCDE (2004), "o trabalho criativo executado de forma sistemática para aumentar o estoque de conhecimento e a utilização dele para novas aplicações". Empresas da indústria manufatureira foram as pioneiras e são exemplos desta época os GE Labs, DuPontLabs, Bell Labs, IBM Research, 3M, Xerox PARC e o Kodak Labs.

Durante a década de 1950, Schumpeter (1950) observou que tais áreas já haviam tomado o lugar dos inventores independentes e o ritmo da inovação nas indústrias era ditado pelas áreas de P\&D. A partir da década de 1990, o advento da tecnologia da informação inaugurou uma nova fase para a inovação nas grandes empresas, marcada pelo surgimento das startups.

As startups são, segundo a FINEP, empresas nascentes de base tecnológica cuja estratégia é sustentada pela inovação e cuja base técnica de produção está sujeita a mudanças frequentes, advindas da concorrência centrada em esforços continuados de pesquisa e desenvolvimento tecnológico. Já Ries (2011) as define de forma mais abrangente, como "uma instituição humana projetada para criar novos produtos ou serviços sob condições de extrema incerteza". Este autor não vincula sua definição ao tamanho da empresa, atividade ou setor da economia.

Historicamente, na indústria manufatureira, a estratégia e as áreas de P\&D trabalhavam em conjunto analisando o impacto que novos competidores, tendências de mercado e novas tecnologias poderiam gerar no modelo de negócio vigente. A estratégia definia os planos de 
lançamento de novos produtos e as áreas de $\mathrm{P} \& \mathrm{D}$ criavam e patenteavam as tecnologias mais inovadoras. Este modelo, no entanto, tornou-se defasado após vigorar por mais de 70 anos.

A partir da década de 1990, financiar startups mostrou ser mais lucrativo do que financiar áreas de P\&D de grandes empresas. O capital privado de alto risco foi, aos poucos, migrando. As grandes empresas tiveram então que cortar custos das áreas de $\mathrm{P} \& \mathrm{D}$, tornandoas mais focadas em analisar os benefícios que poderiam ser extraídos do desenvolvimento de novas tecnologias do que na pesquisa em si. Assim, pesquisadores passaram a trabalhar mais na solução de problemas de curto prazo, que geravam melhoria imediata do modelo de negócio vigente do que com tecnologias mais disruptivas. Consequentemente, o papel das áreas de $P \& D$ das grandes empresas passou a ser prolongar o modelo de negócio vigente, separando-se do risco de estar na vanguarda da inovação, que passou a ser delegado às startups.

O que aconteceu foi uma mudança de paradigma em termos de conhecimento industrial. O paradigma antigo da inovação fechada foi superado pelos princípios da inovação aberta, alterou o modelo vigente de inovação nas grandes empresas. Chesbrough (2003) atribuiu tal superação, principalmente, às mudanças nas áreas de $\mathrm{P} \& \mathrm{D}$, que provocaram a saída de pessoal altamente capacitado para fundar suas próprias empresas ou para fazer parte de startups, e ao capital privado de alto risco, que se especializou em investir em startups que, aos poucos, aumentaram a concorrência com as áreas de $\mathrm{P} \& \mathrm{D}$ das grandes empresas, tirando-as da vanguarda da inovação. O Quadro 6 resume as diferenças de princípio entre o paradigma da inovação fechada e a inovação aberta.

Quadro 6 - Diferenças entre princípios da inovação fechada e da inovação aberta (adapt. CHESBROUGH, 2003)

\section{Inovaç̃̃o fechada}

Os melhores da nossa área trabalham para
nós

Para lucrar com P\&D nós mesmos precisamos descobrir, desenvolver e fornecer resultados

Quando a descoberta é nossa, sempre a lançaremos antes no mercado

A companhia que primeiro lança uma inovação no mercado sempre fica com esse mercado

Se criamos as melhores e mais numerosas ideias na indústria, o sucesso é garantido

\section{Inovaç̃o aberta}

Nem todos os melhores trabalham conosco. Precisamos contar com os melhores dentro e fora de nossa empresa

$\mathrm{P} \& \mathrm{D}$ externa pode criar valor significativo. P\&D interna é necessária para conquistar parte desse valor

Não somos obrigados a gerar pesquisa para poder lucrar com ela

Construir um modelo de negócio melhor é mais útil do que chegar ao mercado primeiro

Se fizermos o melhor uso de ideias internas e externas, o sucesso será nosso 
Um dos documentos que norteia a terminologia da disciplina inovação é o OCDE (2004), documento publicado em 1992 para orientar e padronizar conceitos, metodologias e a construção de indicadores e estatísticas relacionadas à pesquisa, desenvolvimento e inovação. Elaborado por especialistas da Organização para Cooperação Econômica e Desenvolvimento Econômico (OCDE), organização internacional que tem como um de seus objetivos o de estabelecer uma plataforma de referência para políticas econômicas, o documento foi traduzido para o português em 2004 pela Financiadora de Estudos e Projetos (FINEP), empresa pública vinculada ao Ministério de Ciência, Tecnologia e Inovação (MCTI). Desde então, os conceitos têm funcionado como parâmetros de referência nos meios acadêmico e profissional.

Este documento não adota uma definição para o termo inovação. No entanto, é descrito como "mudanças que envolvam um grau significativo de novidade para a empresa”, excluindose aquelas consideradas "mais do mesmo", e caracterizada como uma "atividade complexa e diversificada", que requer a integração de vários componentes, como "oportunidades de mercado, base de conhecimentos e capacidade da empresa” (OCDE,2004). De modo geral, é possível interpretar que, no âmbito do documento, inovação é um conjunto de mudanças implementadas em organização que provoca impactos positivos, que podem ser econômicos ou não.

Para o Innovation Report (2003), inovação é uma exploração bem-sucedida de novas ideias que, quando envolve a utilização de novos conhecimentos para uma determinada cultura, é denominada inovação tecnológica.

Tidd e Bessant (2013) ressaltam a natureza de processo da inovação e defendem que, ao encará-la assim, cria-se um modelo mental a respeito do processo de inovação que contribui para que líderes adquiram consciência e segurança sobre o tema, o que lhes permitirá tomar melhores decisões em suas empresas.

Quando aplicado ao mercado da construção, Sabbatini (1996) e Barros (1996) definem inovação tecnológica na construção civil como um aperfeiçoamento tecnológico ou uma tecnologia construtiva racionalizada efetivamente incorporada ao processo de produção de edifícios.

\subsubsection{Inovação tecnológica e não tecnológica}

Uma maneira de classificar o termo inovação diz respeito à sua natureza, que pode ser tecnológica ou não. Uma inovação é tecnológica quando a sua distinção reside nas características de desempenho dos produtos ou processos envolvidos. Em geral, empresas 
buscam inovações tecnológicas quando o aprimoramento das características de desempenho de seu produto ou processo são fatores relevantes nas vendas (OCDE, 2004).

Por exemplo, é de se esperar um aumento nas vendas de um carro caso seja empregada uma inovação tecnológica de produto ou processo que, pelo mesmo preço, seja capaz de oferecer ao cliente características de desempenho aprimoradas, desde que sejam valiosas para ele, como potência do motor e consumo médio de combustível por quilômetro rodado.

No contexto da construção civil, uma adaptação do termo "inovação tecnológica" foi a adotada por Sabbatini (1989). Segundo o autor, "um novo produto, método, processo ou sistema construtivo introduzido no mercado constitui-se em uma inovação tecnológica na construção de edifícios quando incorporar uma nova ideia e representar um sensível avanço na tecnologia existente em termos de desempenho, qualidade ou custo do edifício ou de sua parte".

Há, no entanto, produtos e processos cujas características de desempenho não são objetivas. Por exemplo, quais são as características de desempenho de uma refeição italiana? E de uma gravata? Até que ponto as características de desempenho e a tecnologia são valiosas para o consumidor nestes casos? Quando a identificação das características de desempenho dos produtos e processos for subjetiva, a inovação não é tecnológica.

Além disso, OCDE (2004) considera como inovações não-tecnológicas todas as atividades de inovação que não se encaixam em suas definições de inovação tecnológica. Ele cita como exemplo alguns tipos de mudanças puramente organizacionais, que não provocam alterações mensuráveis nos resultados de produção ou vendas de uma empresa, como a implantação de técnicas avançadas de gerenciamento, a introdução de estruturas organizacionais significativamente modificadas e a implantação de orientações estratégicas corporativas novas ou substancialmente modificadas.

\subsubsection{Inovação quanto ao objeto focal da inovação}

Outra maneira de classificar o termo inovação mencionada no documento diz respeito ao objeto focal da inovação: de produto, de processo, de marketing e organizacional.

Uma inovação de produto diz respeito a mudanças nos atributos ou no uso pretendido de bens ou serviços que alteram a forma como são percebidos pelos clientes. Uma ressalva importante: o termo produto é utilizado para cobrir bens e serviços. Essa indistinção, porém, não é adequada ao escopo deste trabalho uma vez que há diferenças significativas entre a inovação de bens, que são produtos de empresas manufatureiras, e a inovação de serviços, que são produtos de empresas prestadoras de serviços, como as EEEs. 
Uma inovação de processo diz respeito a mudanças no método de produção de bens ou serviços. Não há, necessariamente, alteração na forma como os bens ou serviços são percebidos pelos clientes e, em geral, a inovação de processo está relacionada a buscas por aumento de produtividade e redução de custos de produção. Isto pode incluir mudanças no equipamento, na organização da produção ou em combinações destas, que podem ou não derivar do uso de novo conhecimento.

Em geral, a distinção entre inovações de produto e de processo torna-se mais clara quando relacionada a produtos da indústria manufatureira. Quando se trata da indústria de serviços, tal distinção desaparece e as inovações de produto e processo se fundem (TIDD e BESSANT, 2013).

Uma inovação de marketing consiste na implementação de novos métodos de marketing, envolvendo melhorias significativas no design do produto, embalagem, preço, distribuição ou promoção. Tem como finalidade abrir novos mercados ou o de reposicionar o produto de uma empresa a partir das percepções do cliente.

Uma inovação organizacional diz respeito a mudanças na maneira de administrar a empresa. Isto pode incluir a introdução de estruturas organizacionais significativamente alteradas, a implantação de técnicas de gerenciamento mais avançadas ou a implantação de orientações estratégicas novas ou substancialmente alteradas (OCDE, 2004). É importante ressaltar que mudanças organizacionais podem ser consideradas tecnológicas desde que provoquem alterações mensuráveis nos resultados de produção ou vendas de uma empresa.

Há na literatura inúmeros outros termos que qualificam a inovação de acordo com seu enfoque. Sawnhey, Wolcott e Arroniz (2006) citam doze: inovação de ofertas, de plataforma, de soluções, de clientes, de experiência do cliente, de obtenção de valor, de processos, de organização, de cadeia de suprimento, de presença de marca e de redes. Terra (2012) cita oito: inovação da solução para o cliente, inovação do segmento de clientes, inovação na experiência do cliente, inovação do modelo de receitas, inovação na cadeia de valor e plataforma, inovação dos canais de comunicação, inovação de networking e inovação de marca. $\mathrm{O}$ autor ressalta que, em qualquer destas situações, a inovação não depende, necessariamente, do desenvolvimento de uma tecnologia original pela própria empresa. Na verdade, em muitas delas não há sequer a aplicação de novas tecnologias.

\subsubsection{Inovação quanto ao grau de novidade}

Outra maneira de classificar o termo inovação diz respeito a seu grau de novidade. É comum as encontrar na literatura os termos inovação incremental e inovação radical. 
Mintzberg, Ahlstrand e Lampel (1998) fazem uma discussão sobre a classificação das inovações em incremental e radical. Os autores consideram que as inovações incrementais e radicais são "faces diferentes da mesma moeda" pois, enquanto algumas podem aparentar serem radicais para um determinado observador, outro pode considerá-las incrementais. Ou seja, tal classificação depende do quão próxima foi a participação do observador no processo.

A inovação incremental pode ser entendida como melhorias contínuas de um produto ou serviço existentes. Para Tidd e Bessant (2013), princípios semelhantes aos utilizados para descrever a inovação incremental sustentam o efeito da chamada "curva de aprendizagem", em que a produtividade é sensivelmente melhorada com o aumento da escala de produção graças à aprendizagem derivada da resolução de problemas que acompanha a introdução de um novo produto, processo ou serviço. A inovação incremental é a base de programas de gestão da "qualidade total", muito comum na indústria manufatureira, ou de gestão utilizando a mentalidade "enxuta".

Diferentemente da inovação incremental, a inovação radical é caracterizada por romper os paradigmas em que as inovações incrementais vêm acontecendo. Trata-se de um conjunto de eventos não corriqueiros que tem a capacidade de alterar as regras de concorrência e competição entre as empresas. Possui diferentes denominações na literatura, chamada de "destruição criativa" por Schumpeter (1947), de "inovação disruptiva" por Christensen (2001) e de "inovação descontínua" por Tidd e Bessant (2013) mas, essencialmente, referem-se ao mesmo fenômeno.

O Quadro 7 mostra alguns dos chamados "gatilhos" da inovação radical e os problemas enfrentados por empresas que se deparam com eles. Para compreendê-lo completamente, é pertinente fazer uma ressalva com relação ao termo "tecnologia", que aparecerá no referido quadro repetidas vezes. A definição adotada para ele foi a de SABBATINI (1989), que é "um conjunto sistematizado de conhecimentos empregados na criação, produção e difusão de bens e serviços". A escolha pela definição deste autor é pertinente para esta dissertação porque ele o particulariza, inserindo-o no contexto da construção civil da seguinte forma: quando uma tecnologia se refere a um particular modo de se construir, emprega-se o termo "tecnologia construtiva", isto é, "um conjunto sistematizado de conhecimentos científicos e empíricos, pertinentes a um modo específico de se construir um edifício (ou partes dele) e empregados na criação, produção e difusão desse modo de construir". 
Quadro 7 - "Gatilhos” da inovação radical e os impactos sobre as empresas que se deparam com eles (adaptado de TIDD e BESSANT, 2013)

"Gatilho"

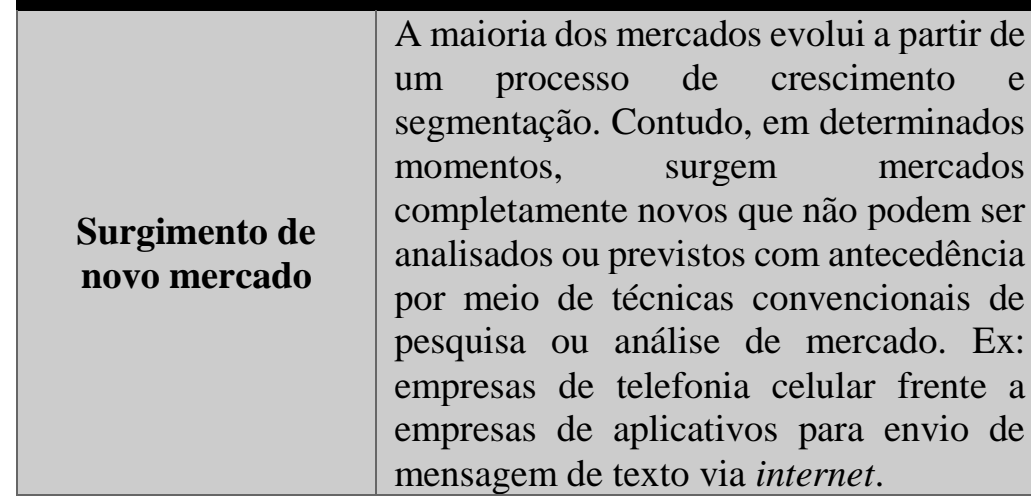

Surgimento de nova tecnologia

\begin{tabular}{|c|}
\hline $\begin{array}{c}\text { Surgimento de } \\
\text { novas regras } \\
\text { políticas }\end{array}$ \\
\hline $\begin{array}{c}\text { Situação sem } \\
\text { perspectivas }\end{array}$ \\
\hline $\begin{array}{c}\text { Mudança de } \\
\text { maré" no } \\
\text { comportamento ou } \\
\text { sensibilidade de } \\
\text { mercado }\end{array}$ \\
\hline $\begin{array}{c}\text { Desregulamentação } \\
\text { ou mudança nos }\end{array}$ \\
\hline
\end{tabular}

Condições políticas que orientam as regras sociais e econômicas podem mudar drasticamente. Ex: mudança em uma economia de planejamento centralizado para uma economia de mercado, como o que aconteceu com a antiga URSS.

Empresas em setores já maduros podem precisar escapar das restrições de produtividade ou do aumento crescente da competição, saindo do negócio ou reorientando-o radicalmente. Ex: empresas como a locadora de vídeos Blockbuster frente a transmissão de vídeos pela internet.

A opinião pública e os comportamentos mudam lentamente e, então, evoluem, criando demanda para novos modelos de negócio. Ex: empresas que ofereciam serviços de download de músicas, como o iTunes da Apple frente a indústria fonográfica tradicional

Pressões políticas ou de mercado levam a mudança na estrutura reguladora e
Problemas enfrentados pelas empresas

Empresas tradicionais não consideram o surgimento de um novo mercado, porque estão concentradas nos mercados existentes. Também podem desconsiderá-lo por ser muito pequeno ou por não representar seu mercado-alvo preferido.

Não é percebida pelas empresas porque se situa além dos limites do cenário de pesquisa de tecnologias delas. Não se trata de uma extensão de áreas já exploradas, mas um campo ou abordagem absolutamente novo. O "gatilho" também pode ser ativado não por um avanço tecnológico isolado, mas por uma convergência do amadurecimento de tecnologias cujo efeito combinatório foi subestimado.

Antigas estruturas mentais sobre administração de empresas ou sobre o ambiente externo de negócio podem ser desafiadas fazendo com que empresas estabelecidas fracassem em compreender e se adequar às novas regras.

Atualmente, empresas que praticam a gestão da inovação estão centradas em um conjunto de rotinas estáveis que militam contra experiências mais audaciosas ou condições de risco mais elevado.

Não levar tais mudanças em consideração ou persistir em explicações alternativas para os novos comportamentos até que seja tarde demais.

Apesar de haver novas regras para o ambiente externo de negócio, os 


\begin{tabular}{|c|c|c|}
\hline $\begin{array}{l}\text { regimes } \\
\text { regulatórios }\end{array}$ & $\begin{array}{l}\text { permitem o surgimento de um novo } \\
\text { conjunto de regras. }\end{array}$ & $\begin{array}{l}\text { modelos mentais antigos persistem e } \\
\text { as empresas tornam-se incapazes de } \\
\text { se adequar rápido o suficiente ou de } \\
\text { enxergar novas oportunidades. }\end{array}$ \\
\hline $\begin{array}{l}\text { Fraturas ao longo } \\
\text { de "linhas falhas" }\end{array}$ & $\begin{array}{l}\text { Antigos motivos de preocupação de uma } \\
\text { minoria se impõem (algumas vezes como } \\
\text { resultado de pressão de alguns grupos) e } \\
\text { o sistema muda repentinamente. Por } \\
\text { exemplo a preocupação com a destinação } \\
\text { correta dos resíduos de construção. Ex: os } \\
\text { constantes processos jurídicos que } \\
\text { levaram o McDonald's a alterar seu } \\
\text { cardápio procurando evitar a obesidade. }\end{array}$ & $\begin{array}{l}\text { As regras do jogo mudam } \\
\text { repentinamente e as empresas são } \\
\text { pegas de surpresa ainda } \\
\text { trabalhando com velhos padrões. } \\
\text { Empresas que estejam } \\
\text { trabalhando à margem do } \\
\text { desenvolvimento de alternativas } \\
\text { paralelas podem subitamente } \\
\text { passar à liderança, na medida em } \\
\text { que as novas condições os } \\
\text { favorecem. }\end{array}$ \\
\hline $\begin{array}{l}\text { Eventos } \\
\text { imprevistos }\end{array}$ & $\begin{array}{l}\text { Situação impensável e, por isso, empresas } \\
\text { não preparadas para acontecimentos que, } \\
\text { às vezes, literalmente, mudam o ambiente } \\
\text { externo de negócio e estabelecem novas } \\
\text { regras. Por exemplo, o aumento das } \\
\text { exigências relacionadas à segurança } \\
\text { contra incêndio em edificações após o } \\
\text { incêndio na boate Kiss. }\end{array}$ & $\begin{array}{l}\text { Novas regras podem enfraquecer } \\
\text { as empresas existentes ou tornar } \\
\text { algumas de suas competências } \\
\text { desnecessárias. }\end{array}$ \\
\hline $\begin{array}{l}\text { Inovação de } \\
\text { modelo de negócio }\end{array}$ & $\begin{array}{l}\text { Modelos de negócio estabelecidos são } \\
\text { desafiados por uma remodelagem que, } \\
\text { em geral, é imposta por uma nova } \\
\text { empresa que redefine ou remodela o } \\
\text { problema e as consequentes "regras do } \\
\text { jogo" comercial. Ex: serviços de } \\
\text { transporte via aplicativo, como o Uber e } \\
\text { os serviços de taxi convencionais. }\end{array}$ & $\begin{array}{l}\text { Novos entrantes consideram a } \\
\text { oportunidade de oferecer produto } \\
\text { ou serviço por meio de um novo } \\
\text { modelo de negócio e reescrevem } \\
\text { as "regras do jogo". Os } \\
\text { participantes existentes devem, } \\
\text { na melhor das hipóteses, } \\
\text { adequarem-se rapidamente. }\end{array}$ \\
\hline $\begin{array}{l}\text { Alterações nos } \\
\text { paradigmas técnico } \\
\text { e econômico }\end{array}$ & $\begin{array}{l}\text { Inovações trazem alterações nas } \\
\text { tecnologias e no mercado. Envolve a } \\
\text { convergência de uma série de tendências } \\
\text { que resultam em uma "mudança de } \\
\text { paradigma" em que uma "velha ordem" é } \\
\text { substituída. Ex: invenção da máquina a } \\
\text { vapor, advento da internet. }\end{array}$ & $\begin{array}{l}\text { É difícil para as empresas } \\
\text { perceberem quando se rompe um } \\
\text { antigo paradigma até que as } \\
\text { novas "regras do jogo" se } \\
\text { estabeleçam. Até lá, os } \\
\text { participantes existentes tendem a } \\
\text { reforçar seu comprometimento } \\
\text { com a "velha ordem". }\end{array}$ \\
\hline
\end{tabular}

Lemos (2000) define inovação incremental como a introdução de qualquer tipo de melhoria em um produto, processo ou organização da produção dentro de uma empresa sem alteração em sua estrutura industrial. O autor ainda define inovação radical como a introdução de um novo produto, processo ou forma de organização da produção inteiramente nova. Este tipo de inovação pode representar uma mudança estrutural com o padrão tecnológico anterior, originando novas indústrias setores ou mercados.

Terra (2012), por sua vez, distingue os termos inovação incremental e inovação radical ao ressaltar as diferenças entre as características dos processos de inovação necessários para fomentar um e outro. A abordagem do autor é particularmente interessante por evidenciar a 
inovação como uma atividade complexa e dependente de várias características administrativas da empresa, como estratégia, cultura e estrutura organizacional, que devem estar adequadas aos seus objetivos de inovação.

Tidd e Bessant (2013) corroboram essa visão ao afirmar que as maneiras de lidar com mudanças incrementais e mudanças radicais são bastante diferentes em termos da gestão do processo da inovação.

\subsubsection{Inovação quanto ao grau de difusão}

Uma outra maneira de abordar o grau de novidade de uma inovação é considerar seu grau de difusão a partir da primeira implantação. Essa característica é fundamental porque, para gerar impacto, a inovação precisa ser disseminada. Assim, quanto ao grau de difusão, a OCDE (2004) classifica o grau de difusão da inovação como mínimo (novo na empresa), intermediário (novo em uma região ou país) e máximo (novo no mundo).

Isso esclarece uma dúvida comum: uma inovação pode ser considerada como tal apenas se for inédita no mundo? A resposta é não. Um produto novo ou aprimorado de uma empresa pode tornar-se parte de um processo novo ou aprimorado de outra. Tidd e Bessant (2013) ressaltam que o grau de novidade, na verdade, "está no olho de quem a vê".

Por exemplo, um aumento de faturamento de um fabricante de computadores provocado pelo aumento das vendas de um modelo novo de computador com capacidade de processamento superior é um exemplo de inovação tecnológica de produto para a indústria de computadores. Uma das características de desempenho do computador, a capacidade de processamento, foi significativamente aprimorada e, como ela é valiosa para o cliente, as vendas do produto e o faturamento da empresa aumentaram. Se esse computador, ao ser comprado por um escritório de contabilidade, for empregado para reduzir erros grosseiros de cálculo ou para organizar os registros contábeis de forma a diminuir o tempo necessário para encontrar informações específicas, o escritório de contabilidade promoveu, portanto, uma inovação tecnológica de processo. Neste caso, mesmo não tendo sido quem desenvolveu o computador e mesmo não tendo sido o primeiro escritório de contabilidade a adotar um computador, essa empresa inovou.

Embora não utilize exatamente nenhum destes termos, a OCDE (2004) adota uma classificação quanto à novidade para especificar as duas formas diferentes que a inovação tecnológica de produto pode assumir: produto tecnologicamente novo e produto tecnologicamente aprimorado.

Um produto tecnologicamente novo possui características de desempenho ou usos pretendidos diferentes dos produzidos anteriormente. Neste caso, a inovação pode envolver 
tecnologias radicalmente novas, basear-se na combinação de tecnologias existentes, mas aplicando-as a novos usos, ou podem ser derivadas do uso de novo conhecimento. Já um produto tecnologicamente aprimorado possui características de desempenho significativamente aprimoradas. Um produto pode ser aprimorado em termos de melhor desempenho ou menor custo por meio da adoção de componentes ou materiais de desempenho melhor. A substituição de metais por plástico nos equipamentos de cozinha é um exemplo de produto simples tecnologicamente aprimorado pelo uso de componentes com desempenho melhor (OCDE, 2004).

\subsection{A estratégia de inovação}

Nesta dissertação, como visto no Capítulo 2, utiliza-se como definição do termo "estratégia", a manutenção de um padrão de comportamento ao longo do tempo. Neste mesmo capítulo discorre-se sobre diferentes processos de planejamento estratégico, alguns mais adequados ao ambiente das EEE, outro menos. Quando se trata da inserção do processo de inovação no modelo de negócio de empresas, é necessário desdobrá-lo em uma estratégia mais específica denominada estratégia de inovação.

Segundo Terra (2012), a estratégia de inovação tem um escopo muito mais ligado ao mercado, às necessidades dos clientes e ao posicionamento da empresa quanto à inovação. Isso inclui uma série de decisões que devem ser conscientemente tomadas a fim de alinhar toda a empresa em torno de uma agenda corporativa única e voltada à inovação.

Dessa forma, estabelecer uma estratégia de inovação requer um conjunto de definições que servirão de subsídios para a definição de diretrizes, tais como:

- Analisar características do mercado, da demanda, das empresas concorrentes e das tendências emergentes;

- Identificar as necessidades de inovação de diferentes segmentos de clientes nos mercados de interesse da empresa;

- Definir quais serão os mercados que deverão ser priorizados pelos projetos de inovação;

- Definir, para os objetivos organizacionais definidos na estratégia, qual é o objeto focal, o grau de novidade, o grau de difusão pretendido e se as inovações serão ou não de cunho tecnológico;

- Definir qual porcentagem do faturamento anual será destinado à inovação e quais as expectativas sobre o retorno deste investimento. 
Definir estas questões, no entanto, também requer um processo de planejamento estratégico, que deverá levar em consideração os objetivos organizacionais da estratégia previamente definida da empresa. Dependendo dos objetivos da estratégia de inovação, a definição de uma estratégia tecnológica pode ser necessária para viabilizá-la.

A estratégia de inovação e a estratégia tecnológica são diferentes. A estratégia tecnológica é um desdobramento da estratégia de inovação de tal forma que o cumprimento de seus objetivos pode ser necessário para viabilizar a estratégia de inovação. Estas relações de dependência foram exemplificadas na Figura 24.

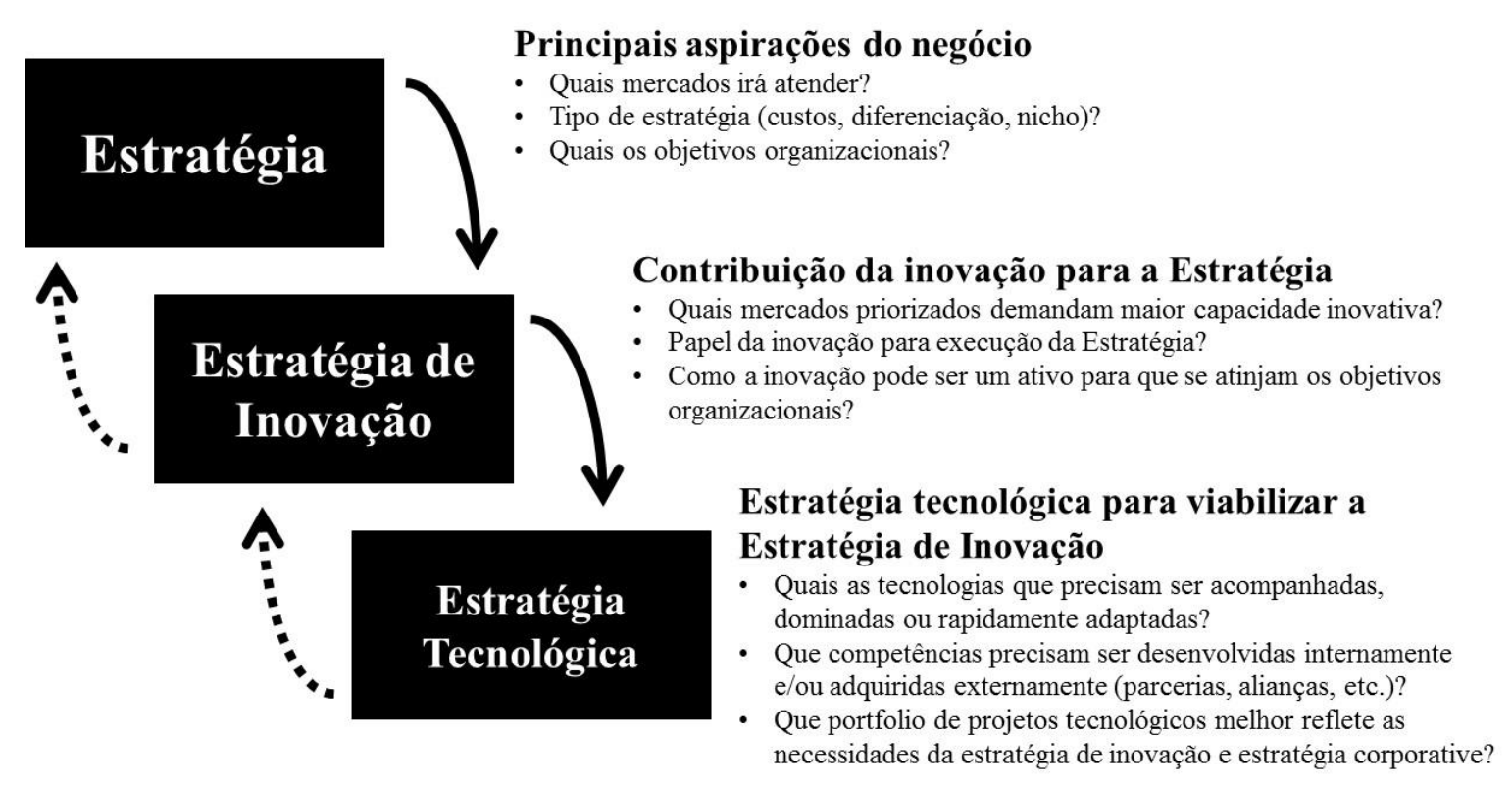

Figura 24 - A relação entre estratégia, estratégia de inovação e estratégia tecnológica (adaptado de TERRA,

2012).

A estratégia tecnológica tem por objetivo assegurar que a tecnologia seja usada como instrumento para alavancar a competitividade da empresa, contribuindo para que a estratégia da empresa seja implementada com sucesso. Isso implica em inovar em produtos e processos antes dos concorrentes, agregando valor para o cliente em termos de desempenho do produto a preços competitivos (VASCONCELLOS, DE TARSO, 1998).

Segundo Terra (2012), a estratégia tecnológica deve definir como a empresa conseguirá os avanços tecnológicos necessários para executar a estratégia de inovação. Este tipo mais específico de estratégia, porém, não será aprofundado nesta dissertação, que se limitará a discutir diretrizes para a estratégia e estratégia de inovação a serem adotadas por EEE a fim de superar as barreiras dos mercados em que atuam. 


\subsubsection{Processo de planejamento estratégico da inovação utilizando os conceitos de modelo de negócio e Horizontes de Inovação}

O processo de planejamento estratégico foi definido no Capítulo 2 como sendo a maneira pela qual uma empresa elabora uma determinada estratégia visando atingir os objetivos organizacionais propostos. Se a estratégia a ser elaborada é a de inovação, tem-se um processo de planejamento estratégico da inovação.

Este item abordará uma sugestão de processo de planejamento estratégico da inovação utilizando dois conceitos: o de modelo de negócio, apresentado no Capítulo 2, e dos Horizontes de Inovação, a ser definido a seguir. Para facilitar a compreensão, será utilizada a ferramenta de representação visual do modelo de negócio, que é o Quadro do Modelo de Negócio (Business Model Canvas), também apresentado no Capítulo 2. Esse método, prático e visual, foi sugerido por Blank (2015) e o autor desta dissertação pode comprovar sua eficácia na época em que era responsável pela gestão técnica e financeira de um projeto de subvenção econômica financiado pela FINEP em uma empresa de execução especializada de serviços de obras (EEE) de alvenaria sediada em São Paulo.

Assim, o processo de planejamento estratégico da inovação utilizando os conceitos de modelo de negócio e Horizontes de Inovação foi escolhido por ter sido utilizado durante a prática profissional do autor. Acredita-se que este é um método eficiente para planejar, escolher uma estratégia de inovação adequada à estratégia da EEE e definir e comunicar as diretrizes às partes interessadas de forma simples, visual e iterativa, uma vez que o aspecto mutável da representação dos modelos de negócio utilizando o Quadro de Modelo de Negócio permite que sejam feitas alterações sempre que se tenha comprovação de que uma das premissas utilizadas na definição da estratégia de inovação seja comprovadamente falsa.

Segundo BAGHAI, COLEY e WHITE (2000), as inovações podem estar classificadas em três Horizontes, dependendo do escopo pretendido para elas.

\subsubsection{O Horizonte 1}

O Horizonte 1 engloba, essencialmente, o universo das inovações incrementais, que estão relacionadas a melhorias na produção de um produto ou na prestação dentro de um modelo de negócio que já é familiar para a empresa. Assim, o mecanismo de funcionamento de seu modelo de negócio é conhecido e os projetos de inovação visam melhorá-lo. Na literatura, os projetos de inovação que utilizam métodos de melhoria contínua como PDCA, Kaizen, Lean, Six Sigma são projetos de inovação do Horizonte 1. 
Neste Horizonte, o objetivo é defender um determinado posicionamento estratégico que já foi conquistado pela empresa por meio, por exemplo, do aumento de eficiência de seu sistema de produção. Para isso, os projetos de inovação têm como objetivo uma alteração nas formas de se realizar determinadas atividades da empresa, isto é, nos seus padrões, nos seus procedimentos, nos seus métodos de execução no intuito de torná-los cada vez mais repetitivos e previsíveis. Em geral, isso é realizado por meio da definição de processos, do detalhamento de procedimentos, da definição de indicadores de desempenho e acompanhamento periódico dos mesmos (BLANK, 2015). Neste Horizonte, as inovações são de baixo risco e o sucesso é resultado de planejamento e implantação eficazes das mudanças pretendidas.

\subsubsection{O Horizonte 2}

O Horizonte 2 engloba as inovações necessárias à uma expansão do modelo de negócio vigente praticado pela empresa. Neste caso, busca-se procura novas oportunidades de se fazer negócio aproveitando-se da experiência e da disponibilidade de recursos do modelo de negócio (BLANK, 2015). Quando uma EEE de alvenaria de vedação de edifícios multipavimento aproveita seu conhecimento técnico, as experiências de seus profissionais, sua reputação e disponibilidade de recursos financeiros para investir no ingresso num mercado novo para ela, como o de alvenaria estrutural de casas térreas, ela desconhece o mecanismo e alguns elementos necessários ao funcionamento desse novo modelo de negócio. Na literatura, o intraempreendedorismo (intrapreneur) e disciplinas de inovação corporativa (corporate innovation) abordam projetos de inovação no Horizonte 2. São exemplos, Kim e Mauborgne (2005) e Blank (2015).

Neste Horizonte, o objetivo é aproveitar o conhecimento acumulado ao longo do tempo pelo funcionamento do modelo de negócio vigente para explorar, por exemplo, mercados com segmentos de clientes com necessidades semelhantes às dos segmentos de clientes que a empresa já atende. Isso pode ser feito por meio de adaptações nos componentes de seu modelo de negócio vigente. Assim, os projetos de inovação buscam reconhecer padrões no funcionamento do modelo de negócio vigente que podem ser aproveitados no funcionamento do modelo de negócio novo (BLANK, 2015). Em suma, as inovações são de médio risco e o sucesso é resultado de experimentação e reconhecimento de padrões semelhantes aos encontrados no modelo de negócio vigente.

Inovações no Horizonte 2 também são chamadas inovações no modelo de negócio. Segundo Chesbrough (2010), as empresas investem consideravelmente em processos de melhoria contínua (Horizonte 1), mas têm pouca ou nenhuma habilidade para inovar o modelo 
de negócio vigente (Horizonte 2). Uma mesma ideia ou tecnologia levada ao mercado por meio de modelos de negócio diferentes podem ter resultados econômicos completamente diferentes.

O desafio de inovar no modelo de negócio é um desafio a ser superado em empresas consolidadas. Para Chesbrough (2010), as principais barreiras enfrentadas pelos inovadores acabam sendo conflitos com o modelo de negócio vigente e a falta de conhecimento para que todos compreendam essa limitação natural. Nestes casos, o autor recomenda que processos de experimentação, coleta e análise de dados devem ser utilizados para embasar as tomadas de decisão sobre projetos de inovação. Além disso, ele sugere que sejam conduzidos processos de transformação organizacional pelas lideranças para que estas barreiras sejam, aos poucos, sendo superadas.

\subsubsection{O Horizonte 3}

O Horizonte 3 engloba as inovações mais ambiciosas e arriscadas, como as inovações radicais. Este Horizonte está relacionado ao empreendedorismo e à exploração de modelos de negócio inteiramente novos que, futuramente, poderão até dar origem a novas empresas. Os profissionais envolvidos em inovações no Horizonte 3 precisam estar fisicamente separados dos profissionais envolvidos no modelo de negócio vigente e dos profissionais de inovação envolvidos em projetos no Horizonte 1 e 2 para que se desenvolva suas próprias políticas, procedimentos e indicadores (BLANK, 2015). Acontece quando, por exemplo, uma EEE de alvenaria de vedação de edifícios multipavimento decide, por exemplo, destacar uma equipe para desenvolver uma fábrica de equipamentos metálicos de serralheria. Na literatura, temas como empreendedorismo e desenvolvimento de startups abordam projetos situados no Horizonte 3. Um exemplo é Ries (2011).

Neste Horizonte, a grande maioria dos componentes do novo modelo de negócio é desconhecido e cercado de condições de extrema incerteza. O objetivo das inovações passa a ser descobri-los por meio de testes sistemáticos das premissas adotadas na elaboração do novo modelo de negócio pretendido. Neste Horizonte, as inovações são de alto risco e o sucesso depende de um senso de urgência e da rapidez em percorrer um ciclo iterativo composto por três partes: teste das premissas adotadas para cada componente do modelo de negócio, aferição dos resultados desse teste e aprendizado. Falhas são esperadas e encaradas como aprendizado necessário ao sucesso da inovação.

A partir da exposição das diversas faces da inovação, a definição que será adotada no âmbito desta dissertação será abrangente e combinada com os conceitos de modelo de negócio e de Horizontes de Inovação: inovação é a implementação de uma mudança planejada em um 
ou mais componentes do modelo de negócio de uma empresa. Essa mudança pode ser simples, visando a uma melhoria qualquer que afete apenas um componente, ou complexa, exigindo que outros componentes do modelo de negócio tenham que ser adaptados.

Uma estratégia de inovação não deve ser formulada de modo a contemplar diretrizes para inovações em apenas um Horizonte. Uma empresa que só inova no Horizonte 1 está fadada a fazer, cada vez melhor, apenas "mais do mesmo". Com o tempo, os componentes de seu modelo de negócio acabam sendo copiados por empresas concorrentes, diminuindo sua participação no mercado e suas margens de lucro. Uma empresa que só inova no Horizonte 2 corre o risco de diminuir sua eficiência por desviar esforços de melhoria contínua de seu modelo de negócio vigente, pois ela "atira para todos os lados”. Uma empresa que só inova no Horizonte 3 arrisca-se demais e corre o risco de não obter retorno algum de seus investimentos em inovação.

Assim, o ideal é, sempre que possível, formular estratégias de inovação contendo diretrizes que distribuam os projetos de inovação nos três Horizontes, investindo mais recursos nos de Horizonte 1 (em geral, baixo retorno sobre investimento, mas riscos menores) e menos recursos nos do Horizonte 3 (em geral, alto retorno sobre investimento, mas riscos maiores). Nagji e Tuff (2012) mencionam que essa distribuição depende da indústria, do posicionamento estratégico e do grau de maturidade da empresa, mas citam exemplos: no caso de uma empresa líder no mercado de bens de consumo, ela distribui os recursos dos projetos de inovação da seguinte maneira $80 \%, 18 \%$ e 2\% (Horizontes 1, 2 e 3, respectivamente). Já uma empresa de tecnologia, $45 \%, 40 \%$ e $15 \%$.

Em suma, a Figura 25 mostra um esquema do retorno esperado ao longo do tempo a partir das diretrizes definidas por uma boa estratégia de inovação: um aumento de riscos e de retorno financeiro mais baixos, mas mais imediatos a partir de inovações incrementais no modelo de negócio vigente; retornos maiores, mas menos imediatos a partir de inovações no modelo de negócio e retornos ainda maiores, mas mais a longo prazo a partir da descoberta de novos modelos de negócio. 


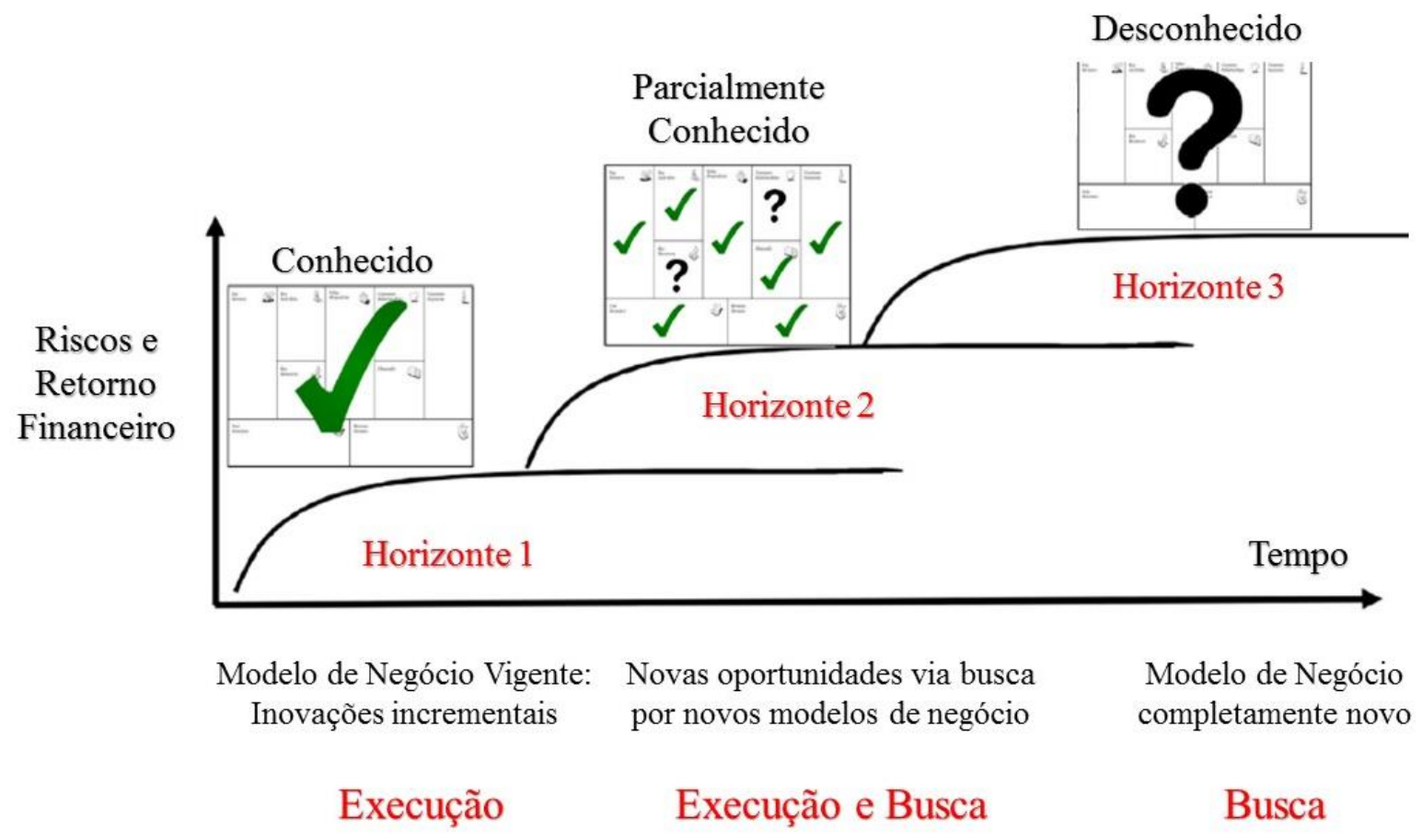

Figura 25 - Riscos e retorno sobre investimento a partir de inovações nos três horizontes (BAGHAI, COLEY e WHITE, 2000). Adaptado de Blank (2015).

\subsection{Características de empresas inovadoras}

De acordo com o Green Paper on Innovation (1995), um dos documentos que embasam o OCDE (2004), uma empresa inovadora tem duas competências:

- Competências estratégicas, que abrangem visão de longo prazo, capacidade de identificar e antecipar tendências de mercado, disponibilidade e capacidade de coligir, processar e assimilar informações tecnológicas e econômicas;

- Competências organizacionais, que abrangem disposição para o risco e capacidade de gerenciá-lo, cooperação interna entre os vários departamentos operacionais e cooperação externa com consultorias, pesquisas de público, clientes e fornecedores, envolvimento de toda a empresa no processo de mudança e investimento em recursos humanos.

No entanto, para inovar, além destas competências, ela precisa descobrir oportunidades, estabelecer uma estratégia apropriada e ter a capacidade de transformar conhecimento em resultado mais rápido que seus concorrentes. E isso é diretamente influenciado por características externas à empresa, relacionadas ao ambiente que a cerca (OCDE, 2004).

Tais características podem ser agrupadas em quatro domínios que compõem, segundo OCDE (2004), o campo das políticas de inovação. São eles: condições estruturais, base de ciência e engenharia, fatores de transferência e dínamo da inovação (Figura 26). A caracterização de cada um deles é feita na sequência. 


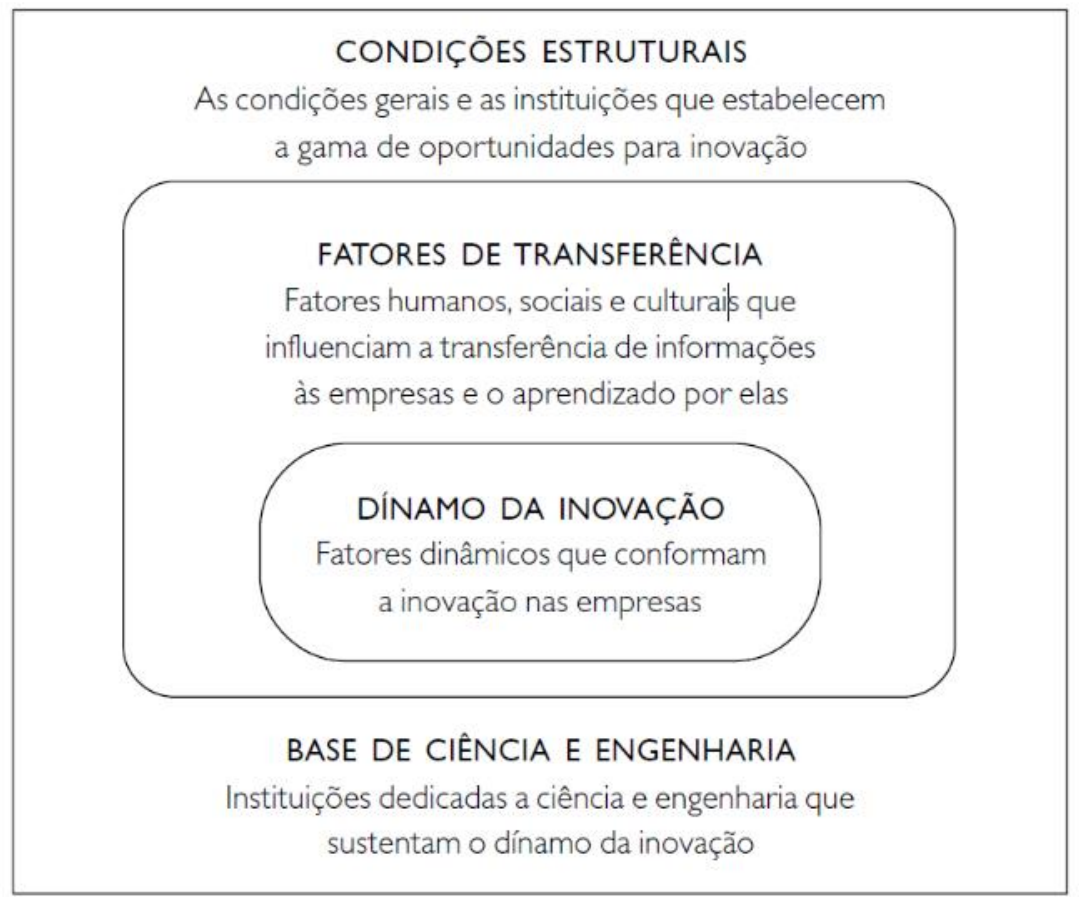

Figura 26 - Campo das políticas de inovação (OCDE, 2004)

O campo das condições estruturais refere-se ao ambiente institucional geral que fornece as condições estruturais nas quais a inovação pode ocorrer. Compreende instituições e certas condições que, em sua maioria, se desenvolveram por razões não vinculadas à inovação. Os elementos que compõem este domínio são:

- Sistema educacional básico da população que determina os padrões educacionais mínimos da mão de obra e do mercado consumidor;

- Infraestrutura de comunicações, como as redes de telefonia, rádio, televisão e Internet e de transporte, como ferrovias, rodovias, portos e aeroportos;

- Instituições financeiras, que determinam, por exemplo, a facilidade de acesso das empresas ao capital de risco, que é o tipo de capital de fomento à inovação;

- Contexto legal e macroeconômico, que inclui a legislação sobre patentes, os impostos e as regras que regem as empresas, e as políticas referentes a juros e taxas de câmbio,

- Acessibilidade ao mercado, que inclui, por exemplo, a possibilidade de se estabelecer relações mais estreitas com os clientes e informações sobre o tamanho do mercado;

- Estrutura da indústria e ambiente competitivo, que inclui a existência de empresas fornecedoras em setores complementares da indústria. 
O campo da base de ciência e engenharia é a base primária das inovações comerciais, que são aquelas que acontecem dentro das empresas. Refere-se à produção de conhecimento científico das instituições de ciência e engenharia, que fornecem entendimento e base teórica. Os elementos que compõem este domínio são:

- Sistema de treinamento técnico especializado;

- As universidades;

- Sistema de apoio à pesquisa básica;

- Atividades públicas e estratégicas de pesquisa e desenvolvimento, como programas de financiamento e instituições voltadas para pesquisa.

O campo dos fatores de transferência refere-se aos fatores humanos, sociais e culturais que são cruciais para uma operação eficaz da inovação no nível das empresas. Esses fatores giram em torno da capacidade de aprendizado pela empresa e se referem à facilidade de comunicação dentro da empresa, às integrações informais, à cooperação e aos canais de transmissão de informações e habilidades entre as empresas e dentro de cada uma individualmente e, por fim, a fatores sociais e culturais que influem na eficácia da operação desses canais e atividades. Os elementos que compõem este domínio são:

- Elos entre empresas, sejam eles formais ou informais, incluindo redes de pequenas empresas, relações entre usuários e fornecedores, agências reguladoras e instituições de pesquisa;

- Presença de "sentinelas" ou receptores com know-how tecnológico, isto é, de indivíduos que se mantenham a par dos desenvolvimentos por meio de uma rede própria e que facilite o fluxo das informações;

- Elos internacionais com especialistas, fundamentais para manter o conhecimento científico e o desenvolvimento tecnológico atualizados;

- Grau de mobilidade de tecnólogos ou cientistas, que pode facilitar ou dificultar a difusão de desenvolvimentos;

- Facilidade de acesso da P\&D públicas pela indústria;

- Formação de novas empresas por divisão (spin-off), que é um meio importante para se chegar à comercialização dos desenvolvimentos;

- Ética, sistemas de valores da comunidade, confiança e abertura que influenciam o ponto até onde os canais de comunicação, como as redes de informação e os elos entre empresas, são eficazes. Isso tem influência direta na relação entre 
indivíduos e, consequentemente, na comunicação, na troca de informações e nas negociações;

- Conhecimento codificado em revistas técnicas, publicações científicas e patentes.

E, por fim, o campo do dínamo da inovação refere-se aos fatores que conformam a inovação no nível da empresa. A propensão que uma empresa tem para inovar depende das oportunidades que ela é capaz de reconhecer e explorar por meio de uma estratégia apropriada que a capacite para transformar investimento em inovação. Esta competência é chamada capacidade inovativa e depende da estrutura organizacional da empresa, de seus recursos humanos, de sua estrutura financeira, de sua estratégia, do mercado em que atua, da concorrência, das alianças que possui com outras empresas e universidades e, acima de tudo, de sua organização interna.

Segundo a OCDE (2004), a capacidade inovativa de uma empresa consiste em um "conjunto de fatores que a empresa tem ou não tem, e nos modos de combiná-los de maneira eficiente". Como boa parte destes fatores estão inseridos em sua força de trabalho, a capacitação da mão de obra é fundamental para o desenvolvimento de uma empresa com foco na inovação. Tidd e Bessant (2012) criaram uma classificação de empresas com base em sua capacidade inovativa. Dependendo do quão ciente da necessidade de inovar e do quão preparada uma empresa está, os pesquisadores criaram quatro classificações: Tipo A, B, C e D.

As empresas Tipo A são "inconscientes” ou desavisadas a respeito dessa necessidade. Elas não possuem os recursos necessários para perceber a necessidade de mudança oriunda, por exemplo, de condições de competição hostis. Em geral, são empresas que, tendo ou não a capacidade de administrar a mudança, simplesmente não percebem a necessidade de fazê-la. Tratam-se de empresas altamente vulneráveis a concorrentes de baixo custo e demandas mais ousadas do mercado.

Empresas Tipo B reconhecem o desafio de inovação, mas não sabem como conduzi-lo de forma eficiente. São empresas que tendem a reagir às ameaças das concorrentes, mas são incapazes de moldar aspectos do mercado a seu favor. Frequentemente não possuem as habilidades e experiência necessárias e não tem uma rede de parceiros externos que as ajude a superar obstáculos fora de sua "zona de conforto".

Empresas Tipo C têm um senso desenvolvido da necessidade de inovação e são altamente capazes de implementar novos projetos, definidos por uma estratégia de inovação e um processo de inovação incremental (Horizonte 1). Têm ideias claras sobre o que precisa ser feito, quando precisa ser feito e quem serão os responsáveis por isso. Em geral, implementam 
a mudança de forma hábil e veloz, mas lhes faltam a capacidade para inovações radicais (Horizontes 2 e 3 ). Tendem a competir dentro das fronteiras de um mesmo segmento de clientes e correm o risco de ficarem "presas" a um crescimento lento. Eventualmente, encontram dificuldades em adquirir novos conhecimentos necessários à superação dos obstáculos de seus projetos de inovação.

Empresas Tipo D operam na fronteira internacional do conhecimento, possuem parceiros diversificados, adotam abordagens criativas e proativas na exploração de novos conhecimentos, tanto tecnológicos, quanto de mercado. Assumem a responsabilidade de "ditar as regras" em seus mercados. Possuem recursos financeiros e alto nível de capacitação de pessoal. Empresas Tipo D podem ser originárias de qualquer setor da economia.

A Figura 27 resume as diferentes capacidades inovativas que as empresas podem apresentar.

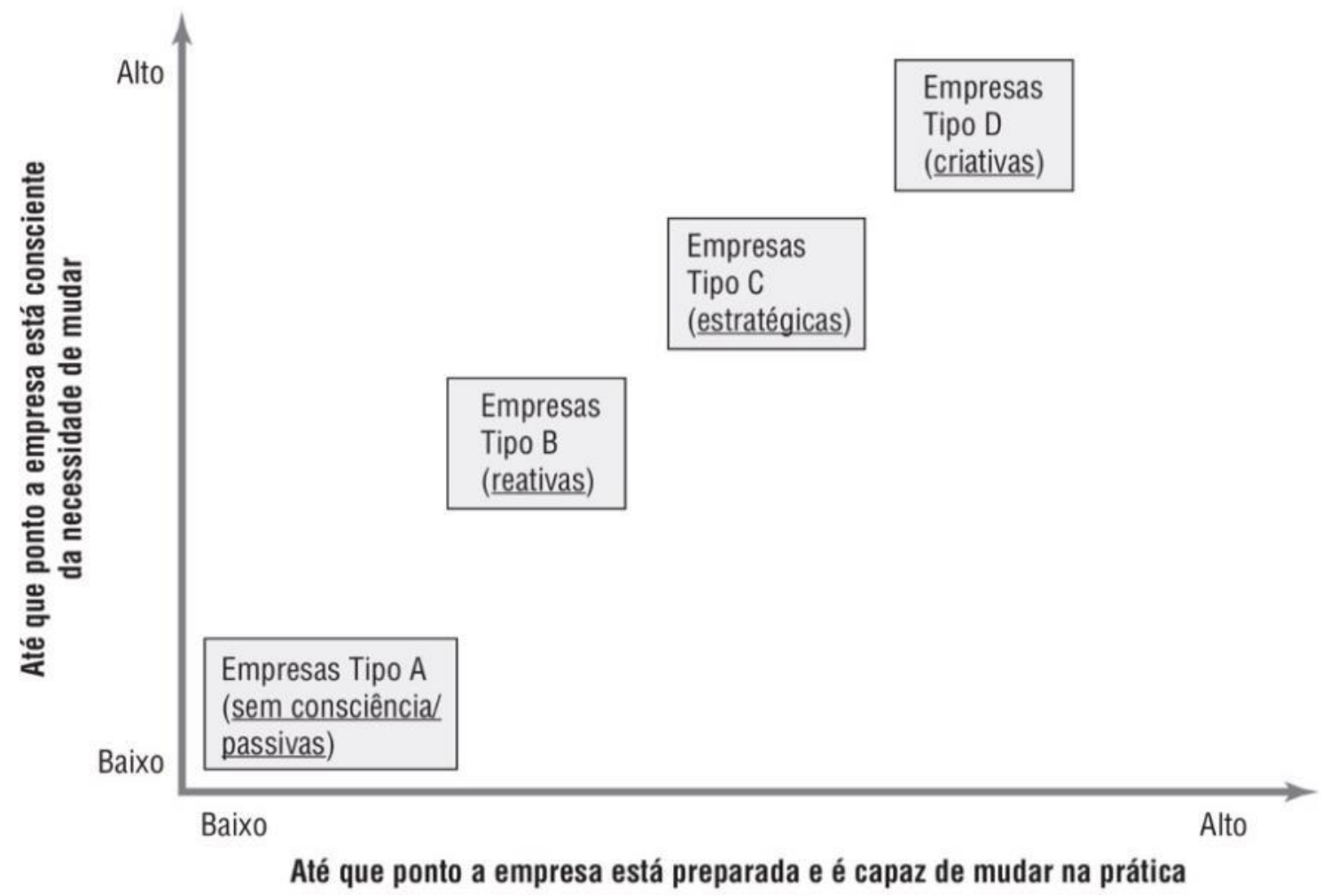

Figura 27 - Capacidade inovativa das empresas (TIDD e BESSANT, 2012).

No entanto, apesar da importância da capacidade inovativa, a condição prévia para a prática sistemática da atividade de inovação em uma empresa é a existência de uma estratégia. É por meio dela que serão tomadas decisões como os tipos de mercado que deverão ser atendidos, os tipos de inovação que neles se tentarão introduzir e a organização interna 
necessária para que isso se realize. Como mostrado por CHIAVENATO (2004), é a estratégia que define os objetivos organizacionais, as políticas, as diretrizes e as metas da empresa que, por sua vez, servirão como input ao processo de planejamento da estratégia de inovação como exposto no item 3.2 .

Uma vez definida a estratégia de inovação, seus objetivos, políticas, diretrizes e metas podem ou não estarem relacionadas à P\&D. Segundo a OCDE (2013), a P\&D “incluem o trabalho criativo empregado de forma sistemática com o objetivo de aumentar o volume de conhecimento, abrangendo o conhecimento do homem, da cultura e da sociedade, bem como a utilização desses conhecimentos para novas aplicações". São exemplos de objetivos vinculados à $\mathrm{P} \& \mathrm{D}$ :

- O engajamento da empresa em pesquisa básica, isto é, em "trabalhos originais empreendidos com o objetivo de adquirir novos conhecimentos sobre os fundamentos de fenômenos e fatos observáveis sem considerar uma aplicação ou uso particular" (OCDE, 2013), a fim de ampliar o entendimento dos processos fundamentais relacionados com o que ela produz;

- O engajamento da empresa em pesquisa aplicada, isto é, em trabalhos originais empreendidos com o objetivo de adquirir novos conhecimentos que serão utilizados para atingir um objetivo prático e bem determinado, a fim de produzir invenções ou modificar técnicas existentes;

- O desenvolvimento de conceitos de produtos ou serviços a fim de julgar se são factíveis e viáveis. Isso pode abranger, por exemplo, um desenho de protótipo ou ensaios;

Por outro lado, os objetivos da estratégia de inovação podem não estarem vinculados à $\mathrm{P} \& \mathrm{D}$, fazendo com que as empresas atuem, por exemplo:

- Na identificação de novos conceitos e tecnologia de produção;

- Na aquisição de informações técnicas por meio de artigos científicos, aquisição de patentes e contratação de consultorias;

- No desenvolvimento (por meio de treinamento) ou na aquisição (por meio de contratação) de competências humanas importantes para a produção;

- Na reorganização de sistemas de gestão ou de produção, bem como em um ou mais de seus processos, métodos e técnicas.

Dada a abrangência de fatores que intervêm na capacidade inovativa das empresas, $o$ escopo desta dissertação foi limitado ao âmbito de um grupo específico de empresas que fazem 
parte do dínamo da inovação: as empresas de execução especializada de serviços de obra (EEE). Mais especificamente, à abordagem de duas características internas a elas: a estratégia e a estrutura organizacional que, entende-se, são capazes de provocar o impacto profundo e necessário para que elas busquem meios de se desenvolver por meio da inovação.

No entanto, embora não esteja no escopo desta dissertação, é importante citar algumas características externas às EEE que influenciam sua estratégia de desenvolvimento com foco na inovação como, por exemplo, as condições desfavoráveis de competição impostas por empresas construtoras e a concorrência desleal presente no mercado de edificações (OVIEDO HAITO, 2010). Estas condições influenciam diretamente em seus resultados financeiros e na manutenção de seu modelo de negócio, o que pode representar um risco à continuidade de seus projetos de inovação.

Outro exemplo é uma característica vinculada ao campo dos fatores de transferência das EEE, isto é, ao campo dos fatores humanos, sociais e culturais que influenciam a transferência de informações às empresas e o aprendizado por elas. Trata-se de um processo holístico denominado acondicionamento, em que elas e suas contratantes, em geral, empresas construtoras, estão submetidas. O acondicionamento resulta de uma sinergia entre sistemas de produção das construtoras e das EEE a fim de materializarem, juntas, uma etapa da obra. Quando o acondicionamento não é realizado no momento certo por um agente qualificado, criase o cenário da improvisação com consequências imprevisíveis ou resultados previsivelmente pobres (OVIEDO HAITO, 2015). Por isso, a formulação de uma estratégia passa, necessariamente, pela superação da negligência dada ao processo de acondicionamento.

Dito isto, dentre as características internas às empresas que influenciam sua estratégia de desenvolvimento com foco na inovação, destacam-se, além da liderança, da estratégia, da estratégia de inovação e da estrutura organizacional, o conflito descrito por Govindarajan e Trimble (2014).

Segundo estes autores, as empresas não foram constituídas para inovar, mas para executarem as atividades de curso contínuo que compõem seu modelo de negócio vigente, quanto mais repetíveis e previsíveis forem tais atividades, mais eficiente e produtivo tende elas tendem a ser. No entanto, como os projetos de inovação são, por definição, não rotineiros e incertos, eles estão sempre em conflito com o modelo de negócio vigente da empresa. Estas incompatibilidades estão resumidas no Quadro 8. 
Quadro 8 - Incompatibilidades fundamentais no modelo de negócio vigente de uma empresa (GOVINDARAJAN e TRIMBLE, 2014).

\begin{tabular}{|c|c|c|}
\hline $\begin{array}{c}\text { Características da execução } \\
\text { do modelo de negócio } \\
\text { vigente da empresa }\end{array}$ & Repetitibilidade & Previsibilidade \\
\hline $\begin{array}{c}\text { Características dos projetos } \\
\text { de inovação de uma } \\
\text { empresa }\end{array}$ & Extraordinariedade & Incerteza \\
\hline
\end{tabular}

Este é um dos principais motivos que dificultam a inserção do processo de inovação nas empresas: os projetos de inovação, por definição, sempre irão visar alterar o funcionamento de algum componente de seu modelo de negócio, por mais que seja uma melhoria simples em algum de seus padrões. Christensen (2001) justifica este comportamento baseado em quatro características do ambiente corporativo: cultura e incentivo de curto prazo, inovações de impacto muitas vezes não focam nos clientes atuais da empresa, mercados pequenos não atendem a necessidade de crescimento das grandes empresas e mercados que não existem não podem ser analisados.

Terra (2012) oferece uma visão sistêmica e integrada das características internas que uma empresa inovadora deve apresentar. Segundo o autor, não basta uma empresa ter ideias, estrutura ou recursos financeiros, mas empresas inovadoras tem um DNA “completamente diferente", em que a inovação "se insere fortemente em seu modelo de gestão, no comportamento de seus profissionais e na forma como ela mesma se relaciona com seu ambiente”. Por isso, não há uma receita única e válida para todas as empresas. Resta, aos interessados, tentar.

Para o autor, há uma composição coerente e interdependente de " 10 dimensões da gestão da inovação" em uma empresa que devem ser analisados a fim de provocar reflexões críticas nos líderes que desejam tentar inserir a inovação em seus modelos de negócio. A partir da definição da estratégia da empresa, a lógica do modelo proposto pelo autor segue os seguintes passos:

1. Necessidade de alinhamento organizacional, obtido por meio de definições da estratégia e objetivos da inovação e da adoção de um modelo organizacional e de governança para inovação;

2. Necessidade de suporte e recursos organizacionais, representado por recursos financeiros, pessoas e uma gestão do conhecimento e infraestrutura tecnológica; 
3. Necessidade de estabelecer um processo de inovação, detalhando os mecanismos de geração de ideias e os processos e estruturas para implementação;

4. Necessidade de mudanças no comportamento e no modelo mental dos profissionais da empresa, por meio de alterações nas formas de mensuração e recompensas, na cultura organizacional e na forma de colaboração interna e externa.

Este esquema é ilustrado na Figura 28.

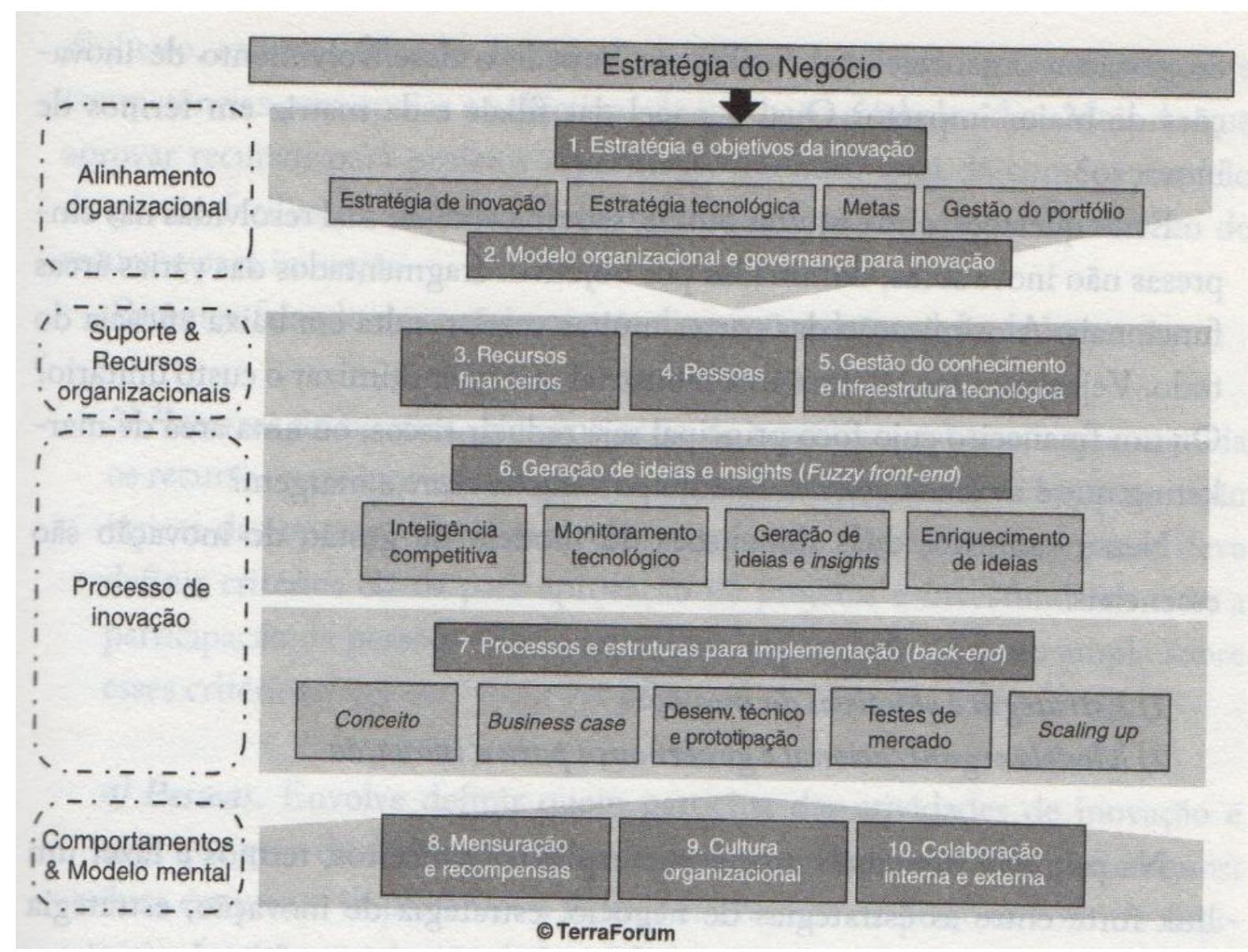

Figura 28 - Modelo das 10 dimensões de gestão da inovação (TERRA, 2012).

\subsubsection{A influência da inovação na estrutura organizacional das empresas}

No Capítulo 2 foi abordada influência que o ambiente e a estratégia exerciam sobre a estrutura organizacional básica de uma empresa. OCDE (2004) cita que um "considerável corpo de pesquisas indica que mudanças tecnológicas e organizacionais estão altamente interligadas", mostrando que a mudança tecnológica "exige mudanças institucionais $e$ organizacionais, ao mesmo tempo que delas decorre". Para Chiavenato (2004), ambientes 
diferentes levam as empresas a adotar estratégias diferentes que exigem estruturas organizacionais adequadas para executá-las.

O mesmo acontece com empresas que desejam praticar sistematicamente a inovação e que, para isso, adotam uma estratégia de inovação: suas estruturas organizacionais também deverão ser alteradas. Apesar das inúmeras diferenças entre elas, há um consenso no meio acadêmico a respeito de um tipo de estrutura organizacional que se mostrou mais eficaz em conciliar as incompatibilidades fundamentais entre a execução do modelo de negócio vigente de uma empresa e seus projetos de inovação: a estrutura organizacional ambidestra (TUSHMAN et al., 2002; MCGRATH, 2010; BLANK, 2015).

Uma estrutura organizacional ambidestra ter como objetivo reunir, numa única estrutura organizacional, duas formas distintas de administrar: uma mais focada em tirar proveito da execução do modelo de negócio vigente, sempre buscando maximizar os lucros e outra focada em encontrar novos modelos de negócio, que garantam novas oportunidades de crescimento à empresa. Naturalmente, tais formas de administrar requerem culturas e competências bem diferentes.

Tushman et al. (2002) investigaram a estrutura organizacional e o impacto gerado pelas inovações na operação e no desempenho de empresas de diferentes setores que, em comum, tinham apenas o fato de buscarem inovação nos três horizontes. Os pesquisadores analisaram 35 projetos situados nos Horizontes 2 e 3 de equipes de inovação de empresas de nove setores diferentes. Mais de $90 \%$ das empresas que adotaram uma estrutura organizacional ambidestra tiveram sucesso em seus projetos. Em outros casos, isto é, nos projetos de empresas que adotaram outros tipos de estrutura organizacional, a porcentagem máxima de sucesso foi de $25 \%$. A Figura 29 mostra a estrutura organizacional ambidestra.

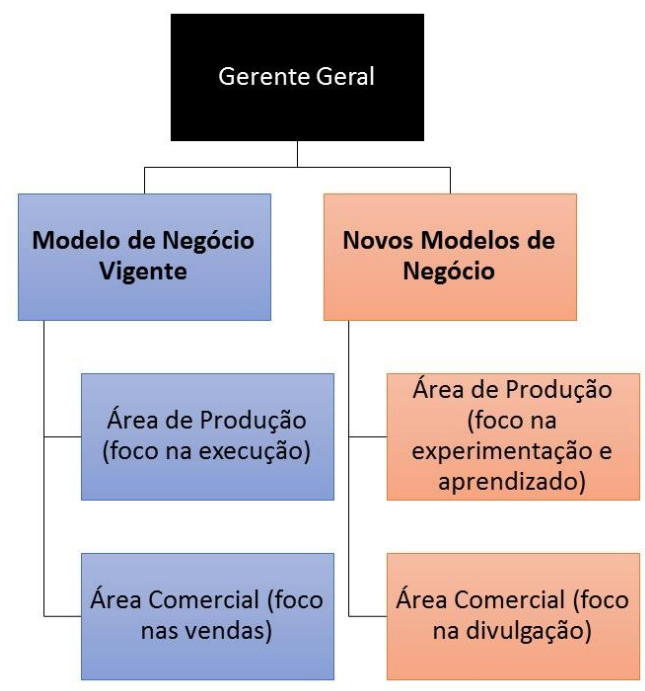

Figura 29 - Estrutura organizacional ambidestra (adaptado de O'REILLY III e TUSHMAN, 2002). 
A intepretação da Figura 29 mostra que, neste tipo de estrutura organizacional, as equipes envolvidas na execução do modelo de negócio vigente da empresa e as equipes envolvidas na busca por novos modelos de negócio são independentes, isto é, possuem processos, estrutura e cultura diferentes, mas estão submetidas à mesma liderança. Essa configuração sugere que as empresas que desejam inovar continuamente têm de adotar uma estrutura organizacional que as permita executar seu modelo de negócio vigente e, ao mesmo tempo, conduzir projetos de inovação nos Horizontes 1, 2 e 3. O Quadro 9 mostra as diferenças entre a administração que visa tirar proveito do modelo de negócio vigente, a administração que visa encontrar novos modelos de negócio e a necessidade de integrar a administração destas duas estruturas sob uma mesma "liderança ambidestra".

Quadro 9 - Características de uma estrutura organizacional ambidestra. A estrutura voltada à exploração do modelo de negócio vigente convive com a estrutura voltada à inovação de modelo de negócio graças à "liderança

\begin{tabular}{|c|c|c|}
\hline & \multicolumn{2}{|l|}{ ambidestra" } \\
\hline & $\begin{array}{c}\text { Exploração do Modelo de Negócio } \\
\text { Vigente }\end{array}$ & $\begin{array}{c}\text { Busca por Novos Modelos de } \\
\text { Negócio }\end{array}$ \\
\hline $\begin{array}{l}\text { Intenção } \\
\text { estratégica }\end{array}$ & Maximizar os lucros & $\begin{array}{l}\text { Encontrar novas oportunidades de } \\
\text { crescimento }\end{array}$ \\
\hline $\begin{array}{l}\text { Atividades } \\
\text { fundamentais }\end{array}$ & $\begin{array}{l}\text { - Execução das tarefas da operação } \\
\text { - Busca por eficiência (inovações } \\
\text { no Horizonte 1) }\end{array}$ & $\begin{array}{l}\text { - Novos produtos e serviços } \\
\text { - Busca por flexibilidade (apoio às } \\
\text { inovações no Horizonte } 1 \text { e } \\
\text { inovações nos Horizontes } 2 \text { e } 3 \text { ) }\end{array}$ \\
\hline $\begin{array}{l}\text { Principal } \\
\text { competência } \\
\text { da liderança }\end{array}$ & Capacidade de administrar & Capacidade de empreender \\
\hline $\begin{array}{l}\text { Características } \\
\text { da liderança }\end{array}$ & $\begin{array}{l}\text { Autoritária, decisões tomadas de } \\
\text { cima para baixo }\end{array}$ & $\begin{array}{l}\text { Visionária e participativa, decisões } \\
\text { tomadas em conjunto }\end{array}$ \\
\hline $\begin{array}{l}\text { Estrutura } \\
\text { organizacional }\end{array}$ & Mecanicista e mais formalizada & Orgânica e menos formalizada \\
\hline Cultura & $\begin{array}{ll}\text { - } & \text { Excelência } \\
\text { - } & \text { Busca pela satisfação dos clientes } \\
\text { - } & \text { Redução de riscos }\end{array}$ & $\begin{array}{ll}\text { - } & \text { Experimentação } \\
\text { - } & \text { Busca por aprendizado } \\
\text { - } & \text { Tomada de riscos }\end{array}$ \\
\hline
\end{tabular}

\section{Liderança Ambidestra}

A liderança ambidestra requer experiência e visão, pois deve equilibrar demandas, manejar recursos e mediar conflitos entre os responsáveis pelos resultados a curto prazo da empresa (isto é, que exploram seu modelo de negócio vigente) e pelos resultados a médio e longo prazo (isto é, que buscam novos modelos de negócio). Também deve garantir a coesão das equipes em torno dos objetivos organizacionais da empresa, compartilhando missão, visão e valores.

A inovação sistemática não requer das empresas apenas uma estratégia, mas também a existência de uma estrutura organizacional adaptada. Segundo O’Reilly III e Tushman (2002) 
e Blank (2015) as empresas precisam estabelecer uma estrutura organizacional ambidestra, em que as equipes de inovação em busca de novos modelos de negócio e as equipes envolvidas na execução do modelo de negócio vigente devem ser independentes técnica e financeiramente, mas é conveniente estarem submetidas à mesma liderança pois, ao mesmo tempo que o vínculo garante formas de compartilhamento de recursos entre os modelos de negócio vigente e futuro, a separação assegura que as equipes de inovação tenham a autonomia necessária para desenvolverem seus projetos independentemente da cultura, da estrutura e dos processos estabelecidos no modelo de negócio vigente da empresa.

\section{Estratégia e inovação em uma empresa de execução especializada de serviços de obra de alvenaria}

De acordo com a Classificação Nacional de Atividades Econômicas (CNAE), a indústria da construção está subdividida em três partes: construção de edifícios, que compreende as construção de edifícios para usos residenciais, comerciais, industriais, agropecuários e públicos; a construção de obras de infraestrutura, que compreende a construção de auto-estradas, vias urbanas, pontes, túneis, ferrovias, metrôs, pistas de aeroportos, portos e redes de abastecimento de água, sistemas de irrigação, sistemas de esgoto, instalações industriais, redes de transporte por dutos (gasodutos, minerodutos, oleodutos) e linhas de eletricidade, instalações esportivas, etc.; e os serviços especializados para construção, que compreendem as empresas responsáveis pela execução de partes de edifícios ou obras de infraestrutura, tais como: a preparação do terreno para construção, a instalação de materiais e equipamentos necessários ao funcionamento do imóvel e as obras de acabamento.

Ainda segundo o CNAE, a construção de edifícios e construção de obras de infraestrutura pode ser realizadas por meio da subcontratação de terceiros, que se responsabilizam pela execução de partes ou do todo da obra. Dependendo das características do serviço que executam ou da forma pela qual são contratadas encontra-se, na literatura, designações diferentes para essas empresas de serviços especializados para construção.

A Figura 30 mostra, de maneira simplificada, classificações de vários tipos diferentes de empresas de serviços especializados para a construção que integram o mercado de construção de edifícios, como as empresas de serviços de obras subempreitadas (SE), as empresas executoras de serviços complexos de obras (ESC) e as empresas de execução especializada de serviços de obra (EEE). Juntos, elas compõem as empresas executoras de serviços de obras (EES). 


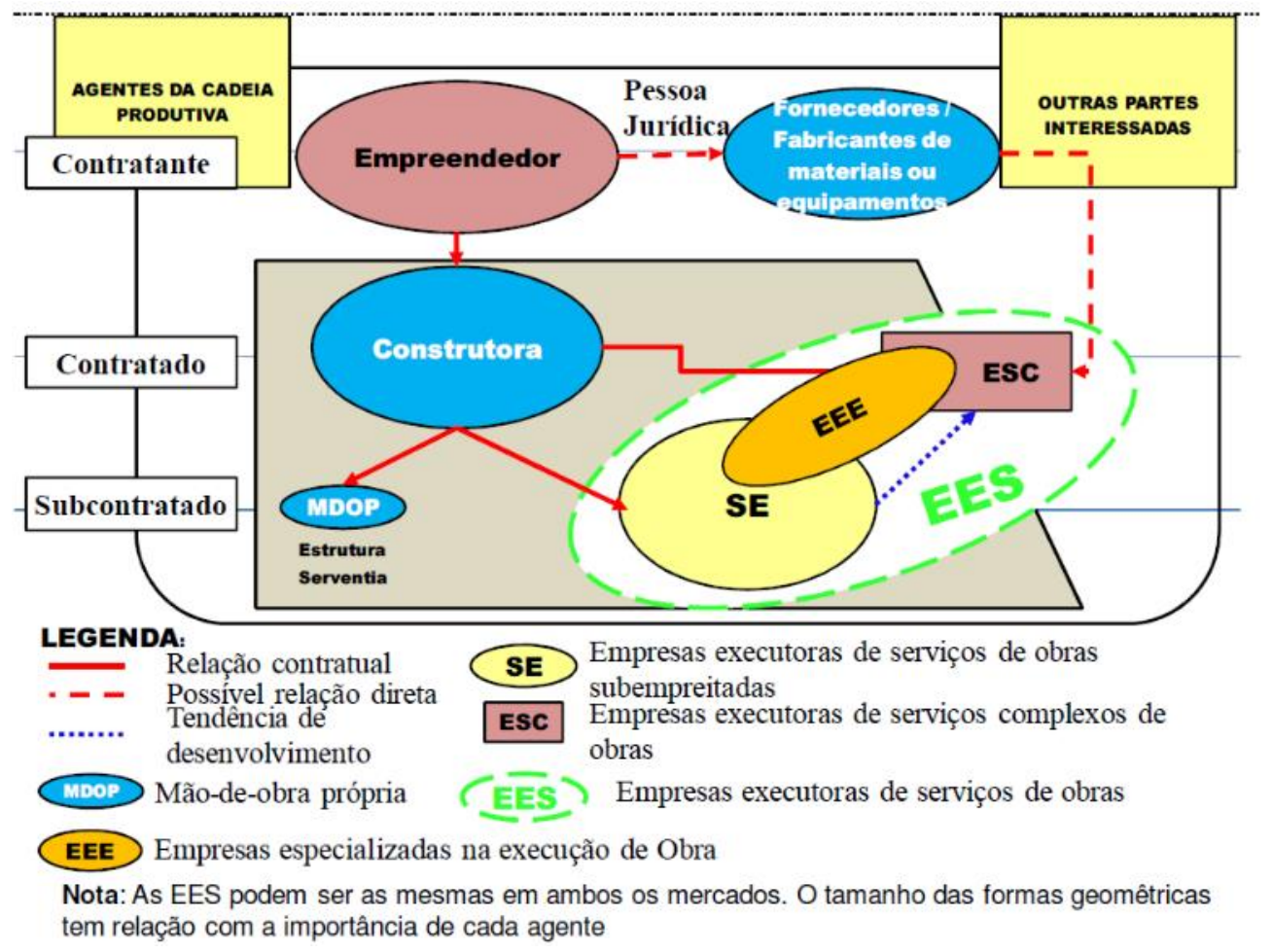

Figura 30 - Composição e participação das EES no setor de edificações da indústria da construção civil (OVIEDO HAITO, 2010).

Como dito anteriormente, as empresas de execução de serviços de obra (EES) desempenham atividades de produção de partes do empreendimento, sendo contratadas em regime de sub empreitada, onde é definido o chamado escopo comercializado para a prestação de serviço (ECS), que poderá incluir o fornecimento de mão de obra, material, projeto, responsabilidade técnica, garantia de execução, manutenção ou, dependendo da EES, de combinações desses elementos (OVIEDO HAITO, 2010).

Quando as empresas construtoras não assumem completamente a responsabilidade legal pela execução de suas atividades de produção e a compartilham com seu contratante, trata-se de um tipo específico de sub empreitada: a subcontratação. Por outro lado, se tais atividades forem realizadas com total autonomia, incluindo responsabilidade técnica, controle de execução e garantia de assistência técnica, o tipo específico de sub empreitada é a terceirização (SOUZA e MELHADO, 1991; FARAH, 1993; PEREIRA, 2003). Por isso, as empresas executoras de serviços de obras (EES) também são comumente chamadas de subempreiteiras, subcontratadas, terceirizadas ou, ainda, de empresas especializadas, empresas especializadas de serviços de execução, empresas prestadoras de serviços, empresas prestadoras de serviços especializados. No exterior, há também várias denominações como subcontractor, trade contractor, specialty contractor, specialty subcontractor e specialist subcontractor. As duas primeiras relacionadas 
a serviços menos complexos e as três últimas, a serviços mais complexos, cuja execução requer maior qualificação técnica.

No entanto, Pereira (2003) constata que as empresas que compõem o conjunto das EES são muito heterogêneas se comparadas entre si e diferem, por exemplo, no modo de atuação, no grau de especialização, no porte e nos serviços prestados. Desta forma, há a necessidade de se analisar dois casos particulares e muito diferentes entre si: as empresas de execução de serviços de obras subempreitadas (SE) e as empresas de execução especializada de serviços de obra (EEE).

As empresas do primeiro grupo, isto é, as empresas de execução de serviços de obras subempreitadas (SE), são caracterizadas como "empresas estruturadas de maneira informal e não profissional, com centralização do poder de tomada de decisão no dono. São carentes de estratégia e de planejamento e controle. Os canais de comunicação são diretos, apoiados na linguagem oral" (CARDOSO, 2003). Também são descritas por Oviedo Haito (201) como "carentes de recursos, pouco desenvolvidas tecnologicamente, com baixa capacitação processos gerenciais e operacionais, com pouco poder de negociação, não associadas a entidades de classe e dependentes extremos dos pagamentos das medições para o financiamento da sua produção e de qualquer inovação orientada à melhoria do seu desempenho". A grande maioria do conjunto das EES é composta pelas empresas de execução de serviços de obras subempreitadas (SE).

Já as do segundo grupo, isto é, as empresas de execução especializada de serviços de obra (EEE), diferentemente da maioria das empresas de serviços especializados para construção, "utilizam técnicas, métodos, processos e conhecimentos específicos voltados aos serviços de obras que executa, dispondo de profissionais e recursos especializados, capazes de propor soluções de engenharia para seus clientes" (OVIEDO HAITO, 2010). Tais empresas constituem uma parcela pequena do conjunto das EES.

Para que uma empresa de serviços especializados possa ser classificada como SE ou com EEE, ela deve apresentar algumas características particulares, como as mostradas no Quadro 10. 
Quadro 10 - Diferenças entre SE e as EEE e ESC (Adaptado de OVIEDO HAITO, 2010).

\begin{tabular}{|c|c|c|}
\hline Característica & $\begin{array}{c}\text { Empresas de execução de serviços de } \\
\text { obras subempreitadas } \\
\text { (SE) }\end{array}$ & $\begin{array}{l}\text { Empresas de execução especializada } \\
\text { de serviços de obras (EEE) }\end{array}$ \\
\hline Porte & Micro e pequenas empresas & Empresas de médio ou grande porte \\
\hline Formalidade & $\begin{array}{c}\text { A formalização é uma barreira à } \\
\text { sobrevivência da empresa, pois os } \\
\text { encargos tributários e trabalhistas têm } \\
\text { alto impacto na estrutura de custos do } \\
\text { empresa. }\end{array}$ & $\begin{array}{c}\text { A formalização não é uma barreira à } \\
\text { sobrevivência da empresa. }\end{array}$ \\
\hline $\begin{array}{l}\text { Estratégia } \\
\text { competitiva }\end{array}$ & $\begin{array}{l}\text { Competição por menor preço. O } \\
\text { serviço é considerado como } \\
\text { "commodity" por seus contratantes. }\end{array}$ & $\begin{array}{c}\text { Competição por enfoque: menor preço } \\
\text { e por diferenciação. São capazes de } \\
\text { oferecer soluções específicas em } \\
\text { determinadas obras. }\end{array}$ \\
\hline $\begin{array}{l}\text { Estrutura } \\
\text { financeira }\end{array}$ & $\begin{array}{l}\text { Por não serem empresas formalmente } \\
\text { constituídas, não possuem fácil acesso } \\
\text { ao sistema financeiro. }\end{array}$ & $\begin{array}{c}\text { Por serem empresas formalmente } \\
\text { constituídas, possuem acesso ao } \\
\text { sistema financeiro. }\end{array}$ \\
\hline $\begin{array}{l}\text { Proposta de } \\
\text { valor }\end{array}$ & $\begin{array}{c}\text { Fornecem recursos para a implantação } \\
\text { de uma solução, geralmente } \\
\text { desenvolvida pelas empresas } \\
\text { construtoras. }\end{array}$ & $\begin{array}{l}\text { Contribuem com o desenvolvimento e } \\
\text { implantação das soluções propostas } \\
\text { pelas empresas construtoras. }\end{array}$ \\
\hline $\begin{array}{l}\text { Estrutura das } \\
\text { atividades de } \\
\text { vanguarda (front } \\
\text { office) }\end{array}$ & $\begin{array}{l}\text { Domínio técnico incompleto das } \\
\text { atividades de produção de seu escopo } \\
\text { comercializado para a prestação de } \\
\text { serviço (ECS). Podem ter recursos } \\
\text { humanos não especializados atuando } \\
\text { nas atividades de vanguarda. }\end{array}$ & $\begin{array}{l}\text { Domínio técnico completo das } \\
\text { atividades de produção de seu escopo } \\
\text { comercializado para a prestação de } \\
\text { serviço (ECS). Possuem apenas } \\
\text { recursos humanos especializados } \\
\text { atuando nas atividades de vanguarda. }\end{array}$ \\
\hline $\begin{array}{l}\text { Estrutura das } \\
\text { atividades de } \\
\text { retaguarda (back } \\
\text { office) }\end{array}$ & $\begin{array}{l}\text { Não contam com respaldo técnico da } \\
\text { retaguarda. Muitas vezes, o dirigente } \\
\text { da empresa está envolvido diretamente } \\
\text { nas operações físicas de produção do } \\
\text { serviço. Geralmente seguem a } \\
\text { programação fornecida pelas empresas } \\
\text { construtoras. }\end{array}$ & $\begin{array}{l}\text { Contam com respaldo técnico da } \\
\text { retaguarda, geralmente integrado pelo } \\
\text { dirigente da empresa e um ou mais } \\
\text { colaboradores. Influenciam na } \\
\text { programação da obra, uma vez que } \\
\text { possuem seus próprios produtos e } \\
\text { processos. }\end{array}$ \\
\hline Garantia & $\begin{array}{l}\text { Não oferecem garantia pelo resultado } \\
\text { de sua atividade de produção. }\end{array}$ & $\begin{array}{l}\text { Oferecem garantia pelo resultado de } \\
\text { sua atividade de produção. }\end{array}$ \\
\hline
\end{tabular}

No meio acadêmico, é mais comum encontrar trabalhos abordando as SE, que são muito mais numerosas que as EEE. Por exemplo, Serra (2001), que apresenta diretrizes para auxiliar profissionais a melhor selecionar, avaliar, contratar e organizar as SE no canteiro de obras; Lordsleem Jr. e Barros (2003), que mostram ações de organização para o desenvolvimento dos processos comercial, de segurança e de produção das SE visando a um aumento da integração delas com as empresas construtoras; Ohnuma e Cardoso (2003), que apresentam um modelo de processos para a gestão de SE voltado às empresas construtoras e Pereira e Cardoso (2003), que investigaram problemas enfrentados por empresas construtoras e SE.

Estas pesquisas, no entanto, abordam as EES sob a ótica das empresas construtoras, analisando-as como clientes dos serviços prestados por elas. Por isso, as descrições são, em sua 
maioria, de observadores externos a elas e as recomendações tem como objetivo adequá-las aos processos de seus contratantes que, na maioria das vezes, são as empresas construtoras. Abordagens diferentes podem ser encontradas nos trabalhos de Cardoso (2003), que compara as EES brasileiras às suas correspondentes francesas, e Oviedo Haito (2010 e 2015) que, a partir de entrevistas com representantes e clientes dessas empresas, definiu e descreveu as características que contribuem para a competitividade destas empresas.

Considerando a carência de aspectos básicos de administração nas SE, não há sentido em considerá-las no escopo desta dissertação, que tem por objetivo definir diretrizes para formulação de uma estratégia de desenvolvimento com foco na inovação. Parte-se do princípio de que uma empresa que pretende adotar uma estratégia de desenvolvimento com foco na inovação requer, necessariamente, que ela:

- Esteja formalmente constituída;

- Tenha um objetivo de longo prazo bem definido, a partir do qual será elaborada sua estratégia;

- Defina, a partir dos objetivos de longo prazo, os Horizontes de Inovação em que a empresa trabalhará;

- Tenha domínio técnico completo das atividades de produção de seu escopo comercializado de serviço (ECS);

- Conte com o respaldo técnico de profissionais atuando nas atividades de retaguarda (back office).

A constituição formal é fundamental para que se constituam vínculos empregatícios duradouros. Como visto no primeiro parágrafo do Capítulo 1, empresas são organizações constituídas por pessoas e, como visto no item 3.3, uma das dimensões fundamentais à inovação são pessoas e sua capacidade de aprendizado. Assim, a constituição formal é necessária para conferir estabilidade às relações de trabalho, que é o mínimo necessário para estimular a permanência dos profissionais na empresa, acumulando o conhecimento que poderá ser usado como matéria-prima para futuros projetos de inovação.

A prática sistemática da inovação, apesar de complexa, não é obra do acaso. É possível encontrar um padrão básico de mesmo em meio a um processo complexo e repleto de incertezas caso contrário não existiriam empresas com mais de cem anos de existência (TIDD e BESSANT, 2012). Ou seja, a inovação pode ser gerida, mas, para isso, deve ser encarada como um processo que, como tal, deve existir para atingir um objetivo de longo prazo. É a partir deste 
objetivo que deverão ser tomadas decisões a respeito de quais Horizontes de Inovação a empresa irá atuar e que orientará o planejamento da estratégia de inovação.

Como foi discutido no item 3.3.1, a empresa que deseja adotar uma estratégia de desenvolvimento com foco em inovação precisa criar uma estrutura organizacional ambidestra que trabalha tanto para explorar o modelo de negócio vigente, assegurando sua sobrevivência no futuro a curto prazo, quanto para buscar novos modelos de negócio a fim de assegurar sua sobrevivência no futuro a médio e longo prazos. Como qualquer atividade, a prática sistemática da inovação requer recursos financeiros e humanos para acontecer. Se o domínio técnico das atividades de produção do escopo comercializado para a prestação de serviço de uma EES for incompleto, o risco para a exploração bem-sucedida de seu modelo de negócio vigente tornase alto demais e sua sobrevivência no curto prazo é ameaçada. Desta forma, não faz sentido investir na sobrevivência a médio e longo prazos se não há a estabilidade econômica necessária à sua sobrevivência a curto prazo.

Por fim, a adoção de uma estratégia de desenvolvimento com foco em inovação requer que a empresa tenha profissionais atuando em suas linhas de retaguarda. Tendo em vista que a capacidade inovativa de uma empresa depende, basicamente, de sua capacidade de aprendizado e de sua competência na organização do processo de inovação (TIDD e BESSANT, 2012) e que a interação entre os profissionais da retaguarda do canteiro (como encarregados, mestres e engenheiros de obras) e os profissionais da retaguarda do escritório (como gestores de projeto, planejamento, suprimentos e produção) é fundamental para estimular esse aprendizado, a competitividade de uma empresa depende da existência das funções de retaguarda na empresa (OVIEDO HAITO, 2010). Por exemplo, inovações incrementais do Horizonte 1, que estão relacionadas a melhorias no modelo de negócio vigente da empresa, originam-se da análise de problemas sistêmicos que só podem ser encontrados por gestores que atuam no âmbito da administração da empresa. Assim, a permanência dessas empresas no mercado depende, a médio e longo prazos, da existência e manutenção de profissionais que não estão envolvidos diretamente na operação, mas em áreas de administração.

Desta forma, o escopo deste trabalho diz respeito apenas às empresas de execução especializada de serviços de obras (EEE). Porém, como a literatura carece de trabalhos específicos sobre elas, os itens seguintes valem-se, em grande parte, da experiência do autor desta dissertação, que atuou durante dois anos na área de inovação de uma empresa de execução especializada de serviços de obra (EEE) de alvenaria de grande porte sediada em São Paulo. 


\subsection{Os processos e a estrutura de uma empresa de execução especializada de serviços de obras}

Por meio de uma análise das fontes de competitividade de empresas prestadoras de serviços utilizando a Visão Baseada em Processos (PBV), Oviedo Haito (2010) descreveu as EES como um sistema organizado e composto por processos que tem por objetivo satisfazer as expectativas de seus clientes por meio de uma mobilização eficientes de recursos para interpretar, compreender e gerar uma mudança nas atividades do destinatário do serviço. Assim, na visão deste autor, as EES podem ser descritas em função dos chamados macroprocessos, isto é, as rotinas que elas executam para prestar o serviço para o qual foram contratadas. Neste tipo de abordagem, as fontes de diferenciação das empresas residem nestes macroprocessos, ou seja, são eles as fontes para obtenção e manutenção da vantagem competitiva de uma EES perante sua concorrência. Uma listagem e descrição deles foi feita no Quadro 11.

Quadro 11 - Descrição dos macroprocessos que compõem uma EES (OVIEDO HAITO, 2010).

\begin{tabular}{|c|c|}
\hline Macroprocesso & Descrição \\
\hline Planejamento e gestão & $\begin{array}{l}\text { Gerenciamento da estratégia, dos objetivos, da divisão do trabalho e dos } \\
\text { indicadores de gestão empresarial (físicos e financeiros) da EES }\end{array}$ \\
\hline Comercial & $\begin{array}{l}\text { Gerenciamento do ciclo de vida dos contratos de execução dos serviços, } \\
\text { desde a elaboração das ofertas e posterior formalização em contratos, } \\
\text { seu acompanhamento até seu fechamento }\end{array}$ \\
\hline $\begin{array}{l}\text { Tecnologia da } \\
\text { informação }\end{array}$ & $\begin{array}{l}\text { Gerenciamento do sistema de suporte à tomada de decisões e da } \\
\text { documentação das informações das EES }\end{array}$ \\
\hline Assistência técnica & $\begin{array}{l}\text { Gerenciamento da satisfação do cliente no que se refere tanto ao produto } \\
\text { construído, quanto a seu desempenho }\end{array}$ \\
\hline $\begin{array}{c}\text { Marketing } \\
\text { (relacionamento) }\end{array}$ & $\begin{array}{l}\text { Gerenciamento dos relacionamentos das EES com o seu ambiente } \\
\text { externo (p. ex. clientes, fornecedores, etc.) para o desenvolvimento de } \\
\text { ativos }\end{array}$ \\
\hline Contábil/Financeira & $\begin{array}{l}\text { Gerenciamento das movimentações financeiras, aspectos contábeis e } \\
\text { tributários atrelados à atuação das EES }\end{array}$ \\
\hline Suprimentos & $\begin{array}{l}\text { Gerenciamento das ações de logística interna e externa da EES } \\
\text { (aquisição de bens e serviços, distribuição e transporte de materiais no } \\
\text { canteiro, etc.) }\end{array}$ \\
\hline Projeto (de produto) & $\begin{array}{l}\text { Gerenciamento do processo do projeto que define as qualidades do } \\
\text { produto a ser executado }\end{array}$ \\
\hline Projeto (de processo) & $\begin{array}{l}\text { Gerenciamento do processo do projeto que contém as características e } \\
\text { condições nas quais o produto será executado }\end{array}$ \\
\hline $\begin{array}{l}\text { Planejamento da } \\
\text { produção }\end{array}$ & $\begin{array}{l}\text { Gerenciamento da estratégia de execução dos serviços e dos seus } \\
\text { requerimentos em termos de recursos e competências }\end{array}$ \\
\hline Recursos humanos & Gerenciamento das pessoas envolvidas em todas as linhas da empresa \\
\hline Segurança do trabalho & $\begin{array}{l}\text { Gerenciamento da sistemática de segurança e saúde no trabalho adotada } \\
\text { pela EES e sua adequação com as normas vigentes }\end{array}$ \\
\hline Produção & $\begin{array}{l}\text { Gerenciamento das condições de organização e execução do serviço, } \\
\text { bem como da sua preservação e da preservação dos outros serviços } \\
\text { existentes }\end{array}$ \\
\hline
\end{tabular}


Portanto, segundo Oviedo Haito (2010), os macroprocessos são fontes de vantagem competitiva para as EES e descrevem rotinas que podem ser incorporadas ao modelo de negócio vigente de uma EES.

No entanto, adotar um processo de planejamento estratégico clássico, como o preconizado pela teoria neoclássica, pode dificultar a adaptação da empresa a mudanças como, por exemplo, os "gatilhos" da inovação radical mostrados no Quadro 7. Além disso, esse processo condiciona a opção por estratégias que conduzam apenas a um aumento de eficiência na exploração do modelo de negócio vigente sem dar a devida importância a inovações nos Horizontes 2 e 3.

Como discutido no capítulo 2, o ambiente externo de negócio das EES (e, consequentemente, das EEE) é modelável, ou seja, possui poucas barreiras para entrada de novos competidores que são capazes de influenciar as condições de competição e concorrência a que todos os outros estão sujeitos. Isso faz com que novas empresas consigam rapidamente se inserir no mercado, por exemplo, imitando os modelos de negócio mais comuns. Isso acirra a concorrência com as empresas já estabelecidas, acelera o processo de "commodização" dos produtos e serviços e intensifica a "guerra" de preços que, a longo prazo, acaba diminuindo as margens de lucro de todas elas.

Assim, adotar um processo de planejamento estratégico modelável (shaping), como o que utiliza o Quadro de Modelo de Negócio (Business Model Canvas) é mais adequado pois, por oferecer uma forma de representação visual da estratégia, permite encará-la como um trabalho sujeito a alterações e que deve ser constantemente revisado. Além disso, esse processo não condiciona a opção por estratégias que conduzam apenas a um aumento de eficiência na exploração do modelo de negócio vigente, mas também para a busca de novos modelos de negócio contemplando as inovações nos Horizontes 2 e 3 que, a longo prazo, são responsáveis por romper o paradigma da "commodização", da "guerra" de preços e da diminuição da margem de lucro.

Assim, uma outra fonte para obtenção e manutenção de vantagem competitiva de empresas é a prática sistemática da inovação nos Horizontes 1, 2 e 3, ou seja, visando tanto ao aumento de eficiência na exploração do modelo de negócio, quanto à busca por novos modelos de negócio. A inovação deve ser entendida como um macroprocesso que envolve o gerenciamento da estratégia de inovação, da estrutura para inovar e do processo de inovação em si.

Oviedo Haito (2010) também investigou a estrutura organizacional das EES sob a ótica da chamada Lógica de Serviço, propondo uma divisão da organização da produção dessas 
empresas em duas linhas: de vanguarda (front office) e retaguarda (back office). Assim, dependendo da proximidade com o objeto de transformação que será alvo da prestação de serviço, os profissionais de uma empresa prestadora de serviços podem exercer funções que fazem parte da linha de vanguarda, que ficam visíveis ao cliente e estão diretamente relacionadas ao objeto de transformação, ou da linha de retaguarda, que são as fontes de tomada de decisão, não ficam visíveis aos clientes e dão suporte ao trabalho da linha de vanguarda.

Assim, tendo em vista que o objeto de transformação que será alvo da prestação de serviço das EES encontra-se no canteiro de obras, as funções que compõem a linha de vanguarda estão relacionadas a ele. Por outro lado, a linha de retaguarda foi dividida em duas, pois são dois os ambientes de tomada de decisão: o canteiro e o escritório. Oviedo Haito (2010) identificou 8 funções diferentes para essas três linhas das EES, como mostrado na Figura 31.

\begin{tabular}{|c|l|}
\hline Linha & \multicolumn{1}{c|}{ Função } \\
\hline Vanguarda & $\begin{array}{l}\text { Vanguarda da Produção: Composta da mão-de-obra diretamente envolvida } \\
\text { na fabricação do produto final. P.ex. carpinteiro na especialidade técnica de } \\
\text { fôrmas }\end{array}$ \\
\hline Vanguarda & $\begin{array}{l}\text { Retaguarda da Produção: Está composta pelo pessoal que dá suporte à } \\
\text { vanguarda na execução do serviço. P.ex. ajudantes e meio-oficiais na } \\
\text { especialidade técnica de gesso acartonado }\end{array}$ \\
\hline $\begin{array}{l}\text { Retaguarda } \\
\text { do canteiro }\end{array}$ & $\begin{array}{l}\text { Retaguarda Técnica do canteiro envolvida em um canteiro só: Integrada } \\
\text { pelo pessoal de tomada de decisões cujo alcance na empresa encontra-se, } \\
\text { geralmente, restrito a um canteiro só. P.ex. encarregado da especialidade } \\
\text { técnica de alvenaria ou estagiário }\end{array}$ \\
\hline $\begin{array}{l}\text { Retaguarda } \\
\text { do canteiro }\end{array}$ & $\begin{array}{l}\text { Retaguarda Técnica do canteiro envolvida em vários canteiros: Integrada } \\
\text { pelo pessoal de tomada de decisões responsável por vários canteiros de obras } \\
\text { em paralelo. P.ex. engenheiro de obras, fiscal / supervisor da especialidade } \\
\text { técnica de fundações }\end{array}$ \\
\hline $\begin{array}{l}\text { Retaguarda } \\
\text { do canteiro }\end{array}$ & $\begin{array}{l}\text { Retaguarda Administrativa do canteiro: Pessoal de suporte administrativo } \\
\text { atrelado a um ou mais canteiros. P.ex. almoxarife, apontador, etc. }\end{array}$ \\
\hline $\begin{array}{c}\text { Retaguarda } \\
\text { do escritório }\end{array}$ & $\begin{array}{l}\text { Retaguarda Técnica do escritório: Integrada pelo pessoal de suporte } \\
\text { técnico às operações da empresa, cuja base encontra-se no escritório. P.ex. } \\
\text { responsável pelo planejamento da produção }\end{array}$ \\
\hline $\begin{array}{l}\text { Retaguarda } \\
\text { do escritório }\end{array}$ & $\begin{array}{l}\text { Retaguarda Administrativa do escritório: Pessoal atrelado às funções } \\
\text { administrativas da empresa. P.ex. contador, administrador, etc. }\end{array}$ \\
\hline $\begin{array}{l}\text { Retaguarda } \\
\text { do escritório }\end{array}$ & $\begin{array}{l}\text { Diretoria: Função desempenhada pelos tomadores de decisões da empresa de } \\
\text { postos mais elevados, integrada por cargos como dono ou diretor da empresa }\end{array}$ \\
\hline
\end{tabular}

Figura 31 - Linhas de vanguarda e retaguarda e suas funções na estrutura organizacional das EES (OVIEDO HAITO, 2010).

Assim, foi possível construir a estrutura organizacional completa das EES em termos de suas linhas e das funções exercidas por seus profissionais (Figura 32). Dependendo do porte da EES, um único profissional pode acumular múltiplas funções. 


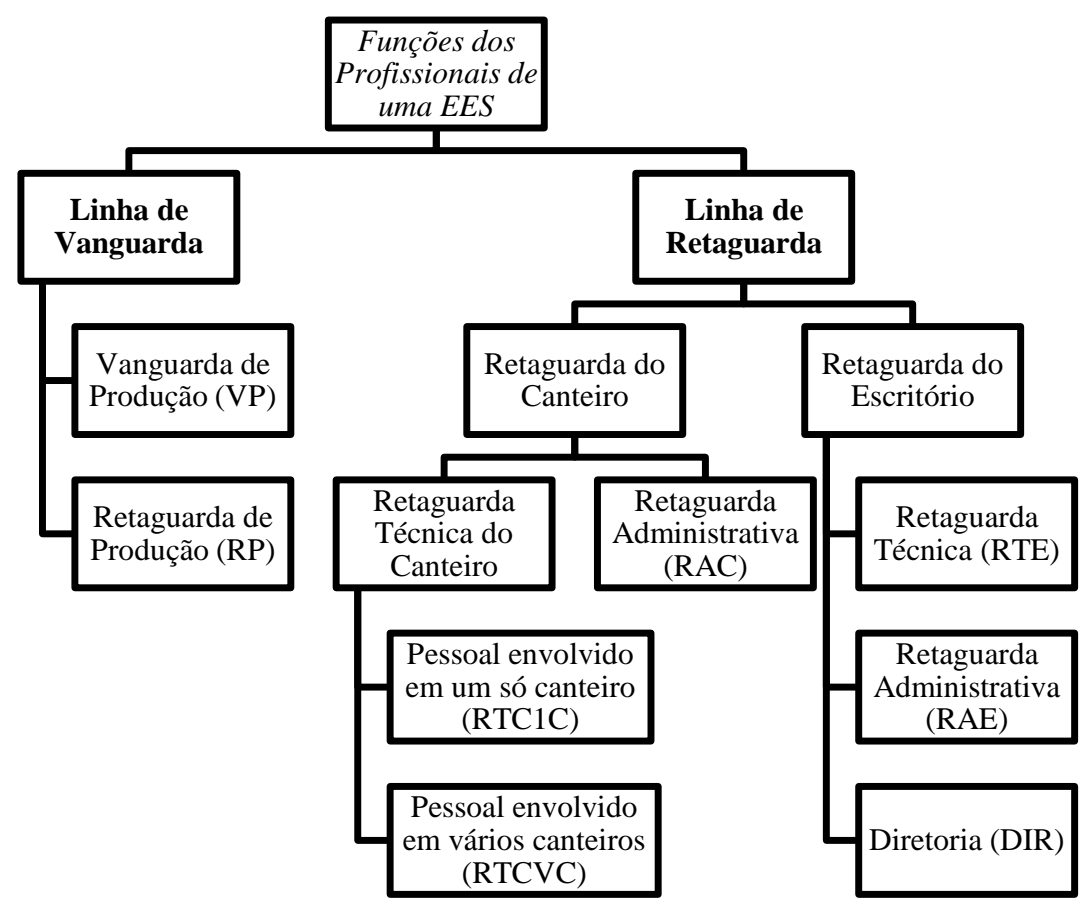

Figura 32 - Estrutura organizacional das EES em termos das funções exercidas por seus profissionais (adaptado de OVIEDO HAITO, 2010).

Posteriormente, por meio de entrevistas a representantes de mais de 20 EES sediadas no estado de São Paulo, Oviedo Haito (2015) pode comparar a estrutura organizacional das EES em termos das funções exercidas por seus profissionais com a presença de macroprocessos que, como dito anteriormente, são fontes potenciais de vantagem competitiva. A ideia era identificar os macroprocessos que mais frequentemente estavam incorporados ao modelo de negócio das empresas e que, consequentemente, serviam como fonte de vantagem competitiva (Figura 33). 


\begin{tabular}{|c|c|c|c|c|c|c|c|c|c|}
\hline \multirow[b]{2}{*}{ Macroprocesso } & \multirow{2}{*}{ 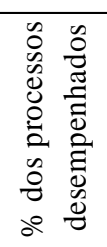 } & \multicolumn{2}{|c|}{ Vanguarda } & \multicolumn{3}{|c|}{ Retaguarda Cant. } & \multicolumn{3}{|c|}{ Retaguarda Esc. } \\
\hline & & $\vec{s}$ & $\hat{z}$ & 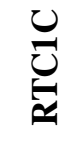 & 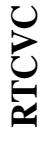 & $\underset{\Xi}{\underline{\Xi}}$ & 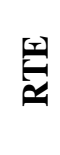 & $\underset{2}{2}$ & $\underline{\underline{a}}$ \\
\hline Suprimentos & $100 \%$ & $\mathrm{X}$ & $\mathrm{X}$ & $\mathrm{X}$ & $\mathrm{X}$ & $\mathrm{X}$ & $\mathrm{X}$ & $\mathrm{X}$ & $X$ \\
\hline Recursos humanos & $100 \%$ & & & $\mathrm{X}$ & $\mathrm{X}$ & $\mathrm{X}$ & & $\mathrm{X}$ & $X$ \\
\hline Produção & $100 \%$ & $\mathrm{X}$ & $\mathrm{X}$ & & $\mathrm{X}$ & & $\mathrm{X}$ & & $\mathrm{X}$ \\
\hline Comercial & $100 \%$ & & & & $\mathrm{X}$ & $\mathrm{O}$ & $\mathrm{X}$ & $\mathrm{X}$ & $X$ \\
\hline Assistência técnica & $100 \%$ & & & $\mathrm{O}$ & $\mathrm{O}$ & & & $\mathrm{X}$ & $\mathrm{X}$ \\
\hline Contábil/Financeira & $96 \%$ & & & & & & & $\mathrm{X}$ & $\mathrm{X}$ \\
\hline Planejamento da produção & $96 \%$ & $\mathrm{O}$ & & $\mathrm{X}$ & $\mathrm{X}$ & & $\mathrm{X}$ & $\mathrm{O}$ & $X$ \\
\hline Segurança do trabalho & $96 \%$ & & & $\mathrm{X}$ & $\mathrm{X}$ & & $\mathrm{X}$ & & $\mathrm{X}$ \\
\hline Planejamento e gestão & $92 \%$ & & & & & & $\mathrm{X}$ & $\mathrm{O}$ & $X$ \\
\hline Marketing (relacionamento) & $83 \%$ & & & & & & & $\mathrm{O}$ & $\mathrm{X}$ \\
\hline Projeto de processo & $63 \%$ & & & $\mathrm{X}$ & $\mathrm{X}$ & & $\mathrm{X}$ & & $X$ \\
\hline Tecnologia da informação & $29 \%$ & & & & & & & $\mathrm{X}$ & $\mathrm{X}$ \\
\hline Projeto de produto & $29 \%$ & & & $\mathrm{O}$ & $\mathrm{O}$ & & $X$ & & $X$ \\
\hline
\end{tabular}

Legenda: X Alta frequência, O Baixa frequência

Figura 33 - Macroprocessos e sua relação com as linhas de vanguarda e retaguarda na estrutura organizacional das EES (adaptado de CARDOSO e OVIEDO HAITO, 2010).

Tendo em vista que os macroprocessos são compostos por conjunto de processos e que as empresas podem ou não tê-los incorporados na totalidade, a coluna "\% dos processos desempenhados" mostra os macroprocessos cujos processos são mais frequentemente desempenhados pelas empresas que compõem o universo da pesquisa. Além disso, os símbolos "X" e "O" foram utilizados para mostrar o quão frequente cada macroprocesso estava presente em cada função desempenhada pelos profissionais das EES pesquisadas.

Assim, as fontes de vantagem competitiva mais comuns eram originárias dos macroprocessos de suprimentos, recursos humanos, produção, comercial e assistência técnica. O processo de suprimentos, nessa análise, pode ser considerado o mais complexo, pois todas as funções da empresa desempenham atividades a ele relacionado.

Uma última análise dos processos e da estrutura das EES foi realizada por Cardoso e Oviedo Haito (2010), que investigaram a relação entre o porte das empresas e das linhas de sua estrutura organizacional. Na pesquisa, foi adotada a classificação segundo o porte do Serviço Brasileiro de Apoio às Micro e Pequenas Empresas (SEBRAE), em que microempresas de 
serviços são aquelas que possuem até 9 funcionários, as pequenas são as que tem de 10 a 49, as de médio porte, de 50 a 99 e as grandes, mais de 100.

Os pesquisadores mostraram que, dependendo do porte da EES, ela pode ou não apresentar todas as funções das linhas de vanguarda e retaguarda, como mostrado na Figura 34. Nela, o símbolo "!" significa "linha emergente" e o símbolo "•", "linha frequente", ou seja, quando a maioria das empresas de determinado porte apresentavam determinada função, esta linha era classificada como frequente. Caso contrário, como linha emergente.

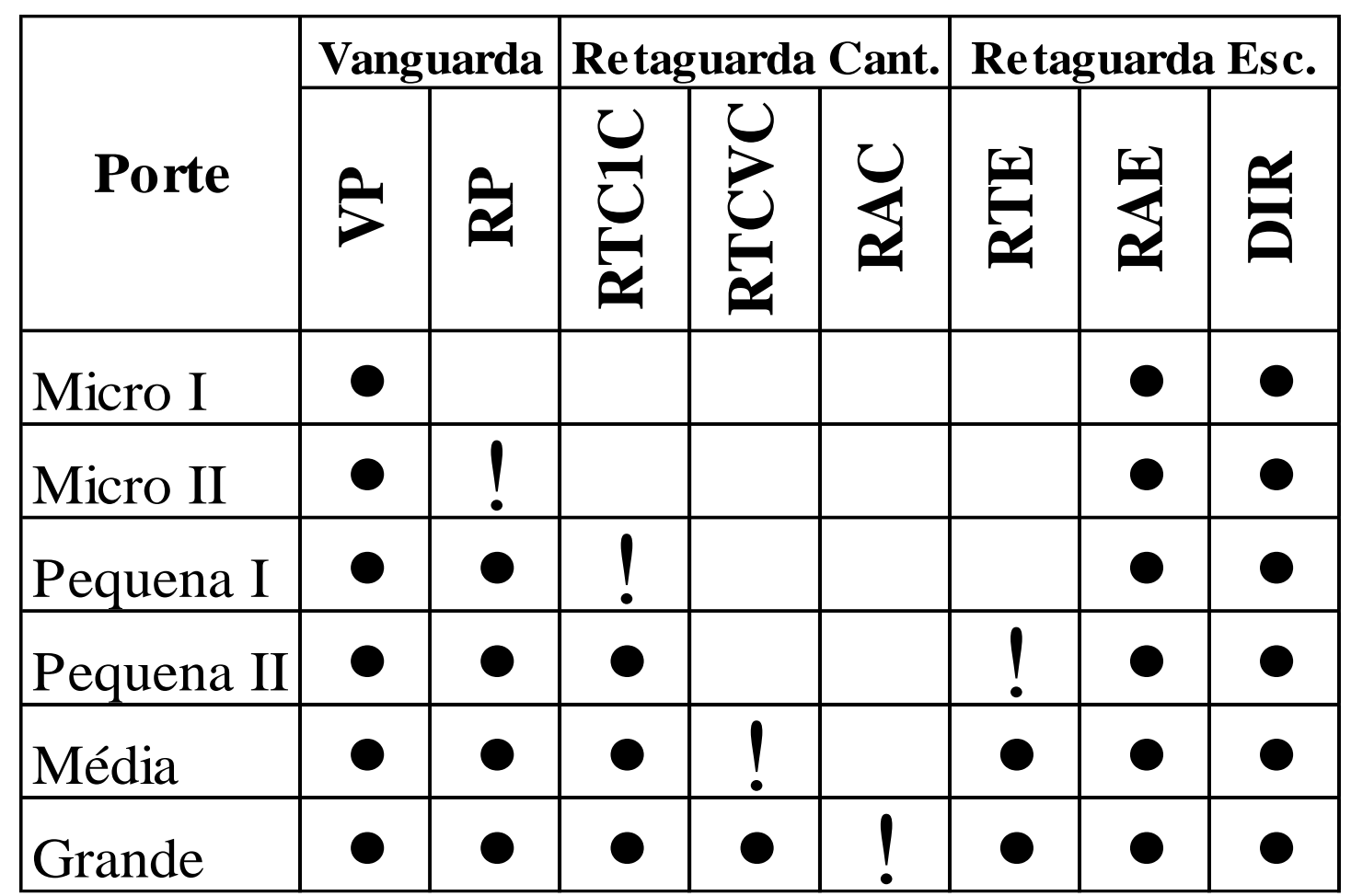

Legenda: • Linha consolidada, ! Linha emergente

Figura 34 - Linhas de vanguarda e retaguarda na estrutura organizacional das EES segundo a evolução de seu porte (adaptado de OVIEDO HAITO, 2015).

Nota-se que empresas de menor porte apresentam, ao menos, as funções VP (Vanguarda de Produção), exercida pela mão de obra diretamente envolvida na construção, RAE (Retaguarda Administrativa do Escritório), exercida pelas pessoas vinculadas às funções administrativas da empresa, como contadores, alocados no escritório, e DIR (Diretoria). As linhas de retaguarda técnica RTC1C (Retaguarda Técnica do Canteiro - Pessoal envolvido em um só canteiro), RTCVC (Retaguarda Técnica do Canteiro - Pessoal envolvido em vários canteiros) e RTE (Retaguarda Técnica do Escritório) inexistem em empresas desse porte. Conforme crescem, a função que passa a ser necessária é a RP (Retaguarda da Produção), que 
faz parte da linha de vanguarda e é uma função de suporte à linha VP (Vanguarda de Produção) na execução do serviço, exercida por ajudantes de obra, por exemplo.

Uma consequência da ausência das linhas de retaguarda técnica são os problemas de comunicação entre profissionais da vanguarda da produção e dificulta, por exemplo, a disseminação de boas práticas por toda a empresa. Eventualmente, os oficiais envolvidos diretamente na produção do produto ou na prestação do serviço podem encontrar, ao longo de sua prática profissional, meios mais eficientes de executar suas atividades. No entanto, a empresa acaba não se beneficiando disso pois não há profissionais na retaguarda técnica para disseminá-lo para todos os outros profissionais. Por isso, nestas empresas, mesmo inovações no Horizonte 1 são difíceis de serem feitas de forma sistemática. Assim, uma das premissas necessárias à inovação no conjunto das empresas executoras de serviços de obras é a presença de linhas de retaguarda técnica RTC1C, RTCVC ou RTE.

\subsection{Natureza da inovação em empresas de execução especializada de serviços de obras}

Existem diferentes maneiras de se descrever uma EES. Como visto anteriormente, é possível fazê-lo, por exemplo, em termos dos macroprocessos que dela fazem parte ou das linhas que ela apresenta em sua estrutura organizacional. Os macroprocessos são fontes de vantagem competitiva para as EES e descrevem rotinas que podem ou não estar incorporadas a seu modelo de negócio. Estes macroprocessos (de planejamento e gestão, comercial, tecnologia de informação, assistência técnica, marketing, contábil/financeira, suprimentos, projeto de produto, projeto de processo, planejamento da produção, recursos humanos, segurança no trabalho, produção e inovação) fazem parte das rotinas incorporadas na execução das funções exercidas pelos profissionais alocados nas linhas de vanguarda e retaguarda de sua estrutura organizacional (vanguarda de produção, retaguarda de produção, retaguarda técnica do canteiro envolvida em um canteiro só, retaguarda técnica do canteiro envolvida em vários canteiros, retaguarda administrativa do canteiro, retaguarda técnica, retaguarda administrativa do escritório e diretoria).

Outra forma de descrevê-las é por meio de seu Quadro de Modelo de Negócio, que contém a proposta de valor da empresa para cumprir certo escopo comercializado de serviço (ECS) e atender a uma demanda de prestação de serviço de um determinado segmento de clientes. Como mencionado anteriormente, a "proposta de valor" aquilo que a empresa irá oferecer ao segmento de clientes, como a produção de um produto ou a prestação de um serviço. Segundo Teboul (2006), é uma expressão clara, convincente e credível da experiência que um cliente receberá, dada por meio de uma proposta de criação de valor mensurável feita por um 
fornecedor. A proposta de valor está relacionada aos clientes, mas também se refere a organização pois articula a essência da empresa, definindo exatamente o que será executado para trazer valor a eles.

É razoável supor que empresas de setores distintos abordem a inovação de formas diferentes. Porém, existem variações significativas mesmo dentro de um mesmo setor. Por exemplo, o setor industrial engloba o universo das indústrias manufatureiras e o universo das indústrias da construção, pois ambas são responsáveis pela transformação de matérias-primas em produtos. Naturalmente, elas se distinguem do setor de comércio e de prestação de serviços. A indústria da construção pode ser, ainda, dividida em três outros segmentos: construção de edifícios, obras de infraestrutura e serviços especializados para a construção segundo a Classificação Nacional de Atividades Econômicas (CNAE).

No entanto, apesar de a abordagem da inovação em empresas do segmento de construção de edifícios, como empresas construtoras e incorporadoras, guardar certa semelhança com a abordagem da inovação em empresas da indústria manufatureira, a abordagem da inovação em empresas do segmento de serviços especializados para a construção, como as EEE, se assemelha mais às características encontradas na inovação de empresas do setor de serviços, que engloba os vastos segmentos de varejo, finanças, transporte, comunicação, entretenimento, serviços públicos e o conjunto dos profissionais liberais.

As características da inovação nos serviços são bastante distintas das características da inovação na indústria. No entanto, na prática, a inovação em empresas de execução especializada de serviços de obras (EEE) acaba mesclando características destes dois universos. Por exemplo: quando uma EEE de alvenaria passa a oferecer, além do produto parede de alvenaria de vedação com blocos cerâmicos para edifícios multipavimentos, um serviço de acompanhamento diário da execução via aplicativo de celular.

Tidd e Bessant (2012) elencam algumas diferenças fundamentais entre a produção de um produto e a prestação de um serviço como os aspectos relacionados a:

- Tangibilidade: produtos são tangíveis, serviços não;

- O fato de que as percepções do desempenho e da qualidade serem mais importantes nos serviços do que nos produtos: serviço bom é aquele que excede a expectativa do cliente;

- Simultaneidade: serviços são gerados e consumidos quase ao mesmo tempo, o que gera dificuldades na gestão da qualidade, no planejamento da capacidade, na identificação e correção de erros; 
- Armazenagem: serviços não podem ser estocados, o que gera dificuldades para equilibrar oferta e demanda;

- Contato com o cliente: quase não há contato com os clientes na produção de um produto, mas muitos serviços exigem níveis elevados de contato com o cliente;

- Localização: simultaneidade e a necessidade de contato com o cliente restringem o espectro da prestação de serviços, diferentemente da produção de produtos.

Também segundo Tidd e Bessant (2013), há uma lacuna no conhecimento da inovação de serviços. Em 2007, pesquisadores da organização britânica National Endowment for Science, Technology and the Arts publicaram um relatório denominado Hidden Innovation. Nele, foram analisadas atividades de inovação que não constavam de indicadores tradicionais de inovação das empresas em seis setores que não eram considerados inovadores: produção de petróleo, operações bancárias de varejo, construção civil, serviços de assistência jurídica, educação e reabilitação de infratores. Eles concluíram haver quatro tipos de comportamento:

- Inovações similares às definições tradicionais, mas excluídas dos indicadores por razões metodológicas;

- Inovações sem grande base científica e tecnológica, como as inovações organizacionais e as de modelo de negócio;

- Inovações criadas a partir da combinação de tecnologias e métodos já existentes;

- Inovações desenvolvidas no âmbito local e em pequena escala, que não são consideradas nem pelos indicadores tradicionais, nem pelas empresas e indivíduos que trabalham no setor.

As inovações que permeavam empresas de construção civil, em geral, não são consideradas nos indicadores oficiais, o que leva a uma compreensão restrita sobre como e com que frequência elas ocorrem.

Segundo Sabbatini (1989) e Barros (1996), a inovação tecnológica em empresas do segmento de construção de edifícios da indústria da construção, é caracterizada pela busca por um processo industrial de construção por meio da adoção de um método para implantar tecnologias mais modernas ao processo de produção do edifício. Isso requer a incorporação de técnicas, métodos e processos construtivos mais eficientes no sistema de produção das empresas, o que exige empenho e disponibilidade de recursos para a realização das mudanças, bem como a existência de uma liderança na condução do processo. Isto pode ou não ser conduzido por departamento de pesquisa e desenvolvimento. 
Segundo Frederick (2010), a inovação em empresas da indústria manufatureira é caracterizada pelo conhecimento de processos, estruturas e ferramentas aplicadas ao desenvolvimento de novos produtos. Apresentam departamentos de pesquisa e desenvolvimento e utilizam processos específicos de desenvolvimento de produtos.

No contexto da administração de empresas, esta é a vertente de pesquisa denominada New Product Development (NPD), caracterizada por desenvolver modelos normativos de como gerir a inovação (projeto de desenvolvimento de novos produtos) elaborando modelos, ferramentas e melhores práticas com o objetivo de estruturar uma empresa para a inovação (FREDERICK, 2010). Um dos exemplos mais conhecidos de ferramenta desta vertente é o modelo chamado funil da inovação, proposto por Clark e Wheelright (1993).

Já a inovação em empresas de serviços segue uma lógica distinta, bem mais recente e menos abordada pela academia que a vertente NPD da inovação em empresas manufatureiras. Por exemplo, frequentemente ela é de natureza imaterial e, portanto, de difícil proteção de propriedade, há um grau de ajuste muito maior às necessidades particulares de cada cliente, há uma maior inter-relação entre o desenvolvimento de novos serviços e os processos que os produzem e as empresas tendem a ser menores e menos concentradas (OCDE, 2004).

Diferentemente das empresas manufatureiras, são raros os exemplos de empresas de serviços com estruturas formais dedicadas à inovação, como um departamento de pesquisa e desenvolvimento. Tal vertente recebeu o nome de New Service Development (NSD) e compreende o processo de desenvolvimento dos serviços e de outros fatores organizacionais (FREDERICK, 2010).

Apesar dessas diferenças, empresas de serviços não raro recorrem a adaptações de estratégias e de estruturas voltadas à inovação encontradas em empresas manufatureiras. Isso é possível porque a proposta de valor dessas empresas possui uma natureza híbrida, mesclando a produção de um produto com a prestação de um serviço. Para Teboul (2006), nas empresas prestadoras de serviço, a proposta de valor é entregue aos clientes por meio da prestação de um serviço, que é a transformação de um bem em valor agregado ao cliente. Essa transformação é composta por um aspecto tangível (transformação de materiais em produto) e por um aspecto intangível (oferecimento de uma experiência ao cliente).

Assim, apesar das adaptações de estratégias e estruturas voltadas à inovação de empresas manufatureiras serem possíveis de se realizar em empresas de serviços (como as EEE) graças à natureza híbrida de sua proposta de valor, os projetos de inovação ora terão características de inovação em produto, o que irá requerer conhecimento e habilidade de gestão específicos para processos de inovação de produto, ora a inovação assumirá características de 
inovação em serviços, o que irá requerer conhecimento e habilidade de gestão específicos para processos de inovação em serviços. Esses processos não serão contemplados no escopo desta dissertação mas elencar características gerais de ambos visando a compará-los com o processo de inovação tecnológica na construção civil é uma reflexão válida.

\subsection{Definição de diretrizes por meio da aplicação do processo de planejamento estratégico da inovação utilizando os conceitos de Quadro de Modelo de Negócio e de Horizontes de Inovação em uma EEE inovadora de alvenaria}

A fim de exemplificar a aplicação do Quadro de Modelo de Negócio no processo de planejamento da estratégia da inovação utilizando o conceito dos Horizontes de Inovação, foi descrito a seguir o raciocínio utilizado para na definição de diretrizes da estratégia de inovação em uma EEE de alvenaria que reunia características de empresa inovadora, tais como a existência de uma estratégia e de uma estrutura organizacional adequadas.

Esse processo foi utilizado pelo autor desta dissertação enquanto atuava na área de inovação de uma EEE de alvenaria sediada em São Paulo. Cada subitem descreverá a lógica por trás da elaboração de diretrizes para projetos de inovação nos Horizontes 1, 2 e 3. O Em todos os casos, a estratégia já havia sido definida levando-se em consideração características do ambiente em que essa empresa se insere e os objetivos organizacionais pretendidos por ela. Com exceção da definição de diretrizes para inovações no Horizonte 3, o autor participou diretamente de todos os outros processos de planejamento.

A empresa em questão era formalmente constituída, administrada de maneira profissional por um líder que reunia habilidades técnicas, relacionadas ao uso de conhecimento especializado e familiaridade com os procedimentos de realização do trabalho; humanas, relacionadas ao trabalho com pessoas e a facilidade de relacionamento interpessoal; e conceituais, relacionadas à visão e a capacidade de planejar o futuro da empresa.

Atuava há 20 anos no mercado de alvenaria de vedação de edifícios multipavimentos. Participou de mais de 400 obras, possuía boa reputação no mercado e uma marca forte construída com foco na inovação. Em 2016, tinha, em média, 10 obras em andamento espalhadas pelos estados de São Paulo e Rio de Janeiro.

Encaixava-se na classificação de EEE, pois era de grande porte (mais de 400 funcionários), possuía uma estratégia voltada à competição por diferenciação, com objetivos organizacionais bem definidos, como aumento de faturamento e aumento das margens de lucro. Sua proposta de valor era a construção de paredes de alvenaria de vedação de blocos cerâmicos, aos clientes a oportunidade de contratar uma empresa que se responsabilizaria por todo o 
processo construtivo das paredes de alvenaria de vedação do edifício, o que engloba a aquisição de todas matérias primas (blocos, argamassa, telas eletrossoldadas, etc.), pela aquisição dos equipamentos, pela elaboração do projeto de modulação, pela execução das paredes de alvenaria de vedação e pela gestão da produção. Era capaz de influenciar a programação da obra, uma vez que possuía o domínio técnico completo de sua especialidade, bem como seus próprios processos.

Possuía um modelo de negócio inovador, tendo sido reconhecida e premiada por isso. Também reunia características de empresa inovadora: considerando-se o modelo das 10 dimensões da gestão da inovação proposto por Terra (2012) e mostradas na Figura 28, é possível afirmar que:

- O processo de planejamento estratégico era adaptado a um ambiente externo de negócio imprevisível e modelável e possuía características semelhantes às preconizadas pela teoria da contingência da administração. Possuía uma estratégia bem definida, capaz de nortear a estratégia e os objetivos da inovação. Embora mantivesse sua essência, estava sujeita a alterações quando eram identificadas mudanças no ambiente externo de negócio da empresa;

- A empresa apresentava características de sistema orgânico: a autoridade era baseada no conhecimento e na consulta, havia poucos níveis hierárquicos, a comunicação era horizontal e informal (devem ser ressaltadas as interações entre as linhas de vanguarda e de retaguarda técnica do canteiro, as interações entre as linhas de retaguarda técnica do canteiro e de retaguarda técnica do escritório e as interações entre as linhas de retaguarda técnica - do canteiro e do escritório, com a diretoria);

- A empresa possuía uma estrutura organizacional ambidestra, mas seu modelo de governança voltado à inovação começava a ser estruturado;

- A empresa possuía recursos financeiros dedicados exclusivamente aos projetos de inovação, contabilizados separadamente;

- A empresa possuía recursos humanos capacitados e experientes nas posições de liderança tanto das linhas de vanguarda, quanto nas linhas de retaguarda do canteiro e do escritório;

- A gestão do conhecimento não era abordada de forma sistemática. No entanto, a comunicação horizontal e informal facilitava o compartilhamento e disseminação de conhecimento tácito entre profissionais por toda a empresa; 
- Não havia processo de inovação formalmente constituído e implantado, mas a geração de ideias e a experimentação eram estimuladas pela diretoria. Os processos e estruturas para implementação das ideias começavam a ser desenvolvidas;

- Não havia formas sistemáticas de mensuração e recompensas por projetos de inovação bem sucedidos;

- A cultura organizacional estimulava a inovação: os profissionais que ocupavam posições de liderança possuíam autonomia para perseguir as metas da empresa, o trabalho em equipe, a experimentação e o aprendizado com os erros eram estimulados pela direção;

- Internamente, os cargos de liderança eram ocupados por profissionais que nutriam um sentimento de respeito e confiança entre si com a diretoria. Havia condições e clima organizacional que fomentavam a colaboração interna. No entanto, uma rede externa de parceiros para atuação em projetos de inovação apenas começava a ser desenvolvida.

Sua estrutura organizacional apresentava todas as linhas da vanguarda (Vanguarda da Produção e Retaguarda da Produção), todas as linhas da retaguarda do canteiro (Retaguarda Técnica do Canteiro - Pessoal envolvido em um só canteiro, Retaguarda Técnica do Canteiro - Pessoal envolvido em vários canteiros e Retaguarda Administrativa) e todas as linhas da retaguarda do escritório (Retaguarda Técnica do Escritório, Retaguarda Administrativa e Diretoria).

Em termos de capacidade inovativa, a empresa pode ser considerada do tipo C (estratégica), segundo a classificação de Tidd e Bessant (2012). Possuía um senso desenvolvido da importância e da necessidade da inovação, era capaz de implementar novos projetos de inovação no Horizonte 1, encarava de maneira estratégica a inovação e possuía boa capacidade técnica e administrativa. Porém, tinha limitações para inovar nos Horizontes 2 e 3, principalmente relacionadas à aquisição de novos conhecimentos, diferentes dos necessários ao negócio tradicional.

\subsubsection{Definição de diretrizes para inovações no Horizonte 1}

Na ocasião do trabalho, entre 2015 e 2016, o modelo de negócio vigente da referida empresa poderia ser representado, de forma simplificada, pelo Quadro de Modelo de Negócio mostrado na Figura 35. 


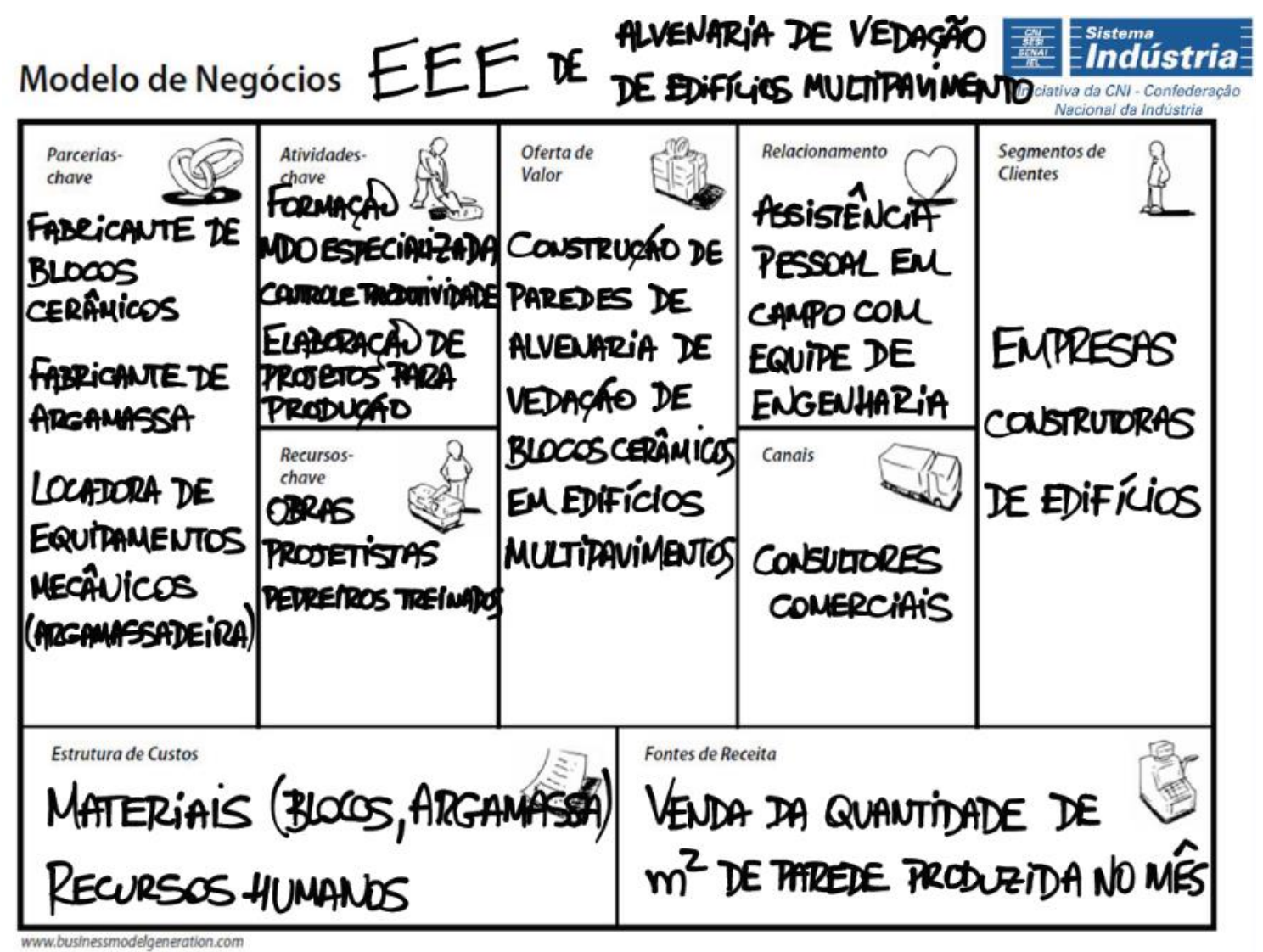

Figura 35 - Quadro de Modelo de Negócio vigente de EEE de alvenaria de vedação de edifícios multipavimento (Fonte: o autor).

Por meio da interpretação da Figura 35, é possível reconhecer o esquema de funcionamento da empresa, ou seja, de seu modelo de negócio vigente, que segue a seguinte lógica:

1. Sua proposta de valor é a construção de paredes de alvenaria de vedação de blocos cerâmicos em edifícios altos;

2. Esta proposta de valor visa atender a um único segmento de clientes: empresas construtoras de edifícios;

3. O relacionamento com este segmento de clientes se dá por meio da assistência pessoal em campo com a equipe de engenharia;

4. Os canais utilizados para levar sua proposta de valor a seu segmento de clientes são visitas periódicas de consultores comerciais;

5. As fontes de receita são a venda da quantidade de metros quadrados de paredes de alvenaria de vedação construídas por mês; 
6. Os parceiros-chave necessários à elaboração da proposta de valor desta empresa são um fabricante de blocos cerâmicos, um fabricante de argamassa e uma locadora de equipamentos mecânicos, como argamassadeira;

7. As atividades-chave que esta empresa deve desempenhar para elaborar sua proposta de valor é a formação de mão de obra especializada na construção de paredes, o controle de produtividade de cada pedreiro e a elaboração de projetos para produção, necessários para que seus pedreiros leiam e interpretem o trabalho a ser feito;

8. Os recursos-chave para a elaboração de sua proposta de valor são a busca por obras de edifícios multipavimentos com paredes de alvenaria de vedação, projetistas para elaboração dos projetos para produção e pedreiros treinados, que utilizem as técnicas construtivas e o método construtivo da empresa;

9. Os principais itens da estrutura de custos necessária para suportar a elaboração de sua proposta de valor são a aquisição de materiais, mais especificamente blocos e argamassa, e a remuneração dos recursos humanos envolvidos.

Dado que o aumento das margens de lucro é um dos objetivos organizacionais definido na estratégia desta empresa e dado que um dos objetivos definidos na estratégia de inovação dessa empresa é inovar apenas no Horizonte 1, é possível identificar, por meio de uma análise do Quadro de Modelo de Negócio, que, para atingir o objetivo organizacional definido, que é o de aumentar as margens de lucro, os projetos de inovações deveriam se concentrar ou no aumento de fontes de receita ou na redução da estrutura de custos.

Considerando-se que a estratégia de inovação da empresa é a de inovar apenas no Horizonte 1, as diretrizes que podem nortear a definição dos projetos de inovação:

- Para uma redução na estrutura de custos: diminuir o desperdício de blocos, diminuir o desperdício de argamassa, aumentar a produtividade dos pedreiros de forma a diminuir a equipe necessária para a execução da mesma metragem quadrada de parede;

- Para o aumento nas fontes de receita: aumentar o preço, aumentar a quantidade de metros quadrados construídos por mês.

Note que nem sempre uma diretriz irá conduzir a projetos de inovação tecnológica. Neste caso, se a diretriz adotada for a de aumento das fontes de receita, é provável que haja a necessidade de definição de, por exemplo, projetos de inovação em marketing.

Outra constatação é a de que, eventualmente, as diretrizes definidas na estratégia de inovação podem requerer a elaboração de uma estratégia tecnológica para viabilizá-la. 


\subsubsection{Definição de diretrizes para inovações no Horizonte 2}

Considerando que o modelo de negócio vigente era o explicitado na Figura 35, uma das diretrizes da estratégia da empresa era explorar o mercado de alvenaria estrutural de habitações de interesse social térreas.

Para isso, deu-se início ao processo de planejamento estratégico visando a identificar os componentes do modelo de negócio vigente que poderiam ser utilizados no novo modelo de negócio de alvenaria estrutural de casas térreas e os componentes do novo modelo de negócio que eram desconhecidos para a empresa. As premissas adotadas para esse novo modelo de negócio foram representadas, de forma simplificada, pelo Quadro de Modelo de Negócio mostrado na Figura 36. As escritas na cor preta correspondem aos componentes do modelo de negócio vigente da empresa que, a princípio, poderiam ser aproveitados no novo modelo de negócio. As escritas em vermelho correspondem a componentes não familiares à empresa, a princípio, necessários ao funcionamento do novo modelo de negócio.

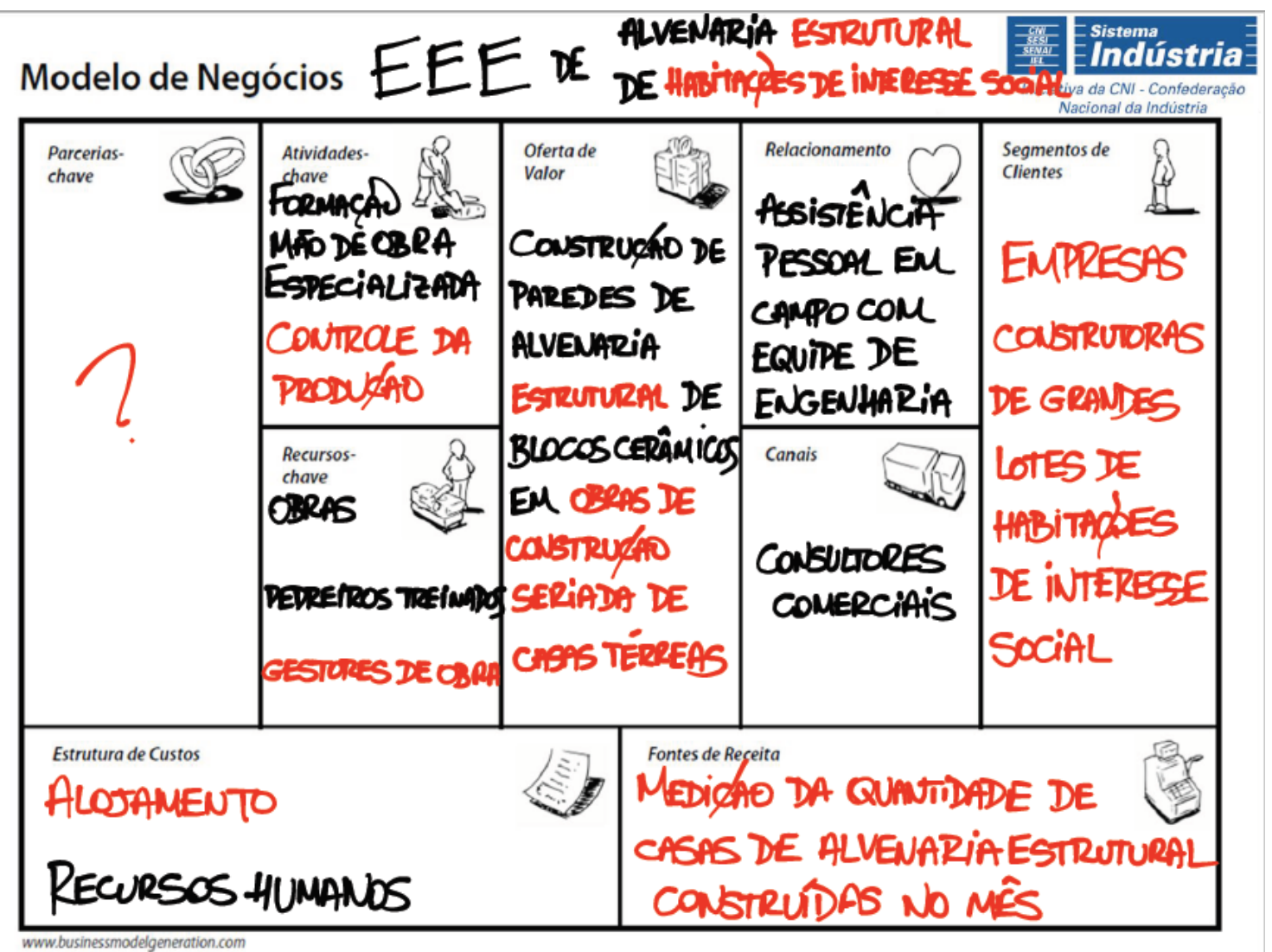

Figura 36 - Quadro de Modelo de Negócio planejado para o ingresso da EEE de alvenaria num mercado adjacente: o de construção seriada de habitações de interesse social (Fonte: o autor). 
Por meio da interpretação da Figura 36, é possível reconhecer o esquema de funcionamento pretendido para o novo negócio da empresa, que segue a seguinte lógica:

1. Sua proposta de valor permanece sendo a construção de paredes, mas a tecnologia utilizada será a alvenaria estrutural de vedação de blocos cerâmicos em obras de construção seriada de casas térreas;

2. Esta proposta de valor passará a atender um segundo segmento de clientes: empresas construtoras de grandes conjuntos de habitações de interesse social;

3. O relacionamento com este segmento de clientes se dará da mesma forma: por meio da assistência pessoal em campo com a equipe de engenharia;

4. Os canais utilizados para levar sua proposta de valor a seu segmento de clientes serão os mesmos: visitas periódicas de consultores comerciais;

5. As fontes de receita não são mais a venda da quantidade de metros quadrados de paredes, passando a ser uma medição da quantidade de casas de alvenaria estrutural construídas no mês;

6. Os parceiros-chave necessários à elaboração da proposta de valor desta empresa ainda não são conhecidos. A princípio, todos os materiais que serão utilizados serão fornecidos pelas empresas construtoras;

7. As atividades-chave que esta empresa deve desempenhar para elaborar sua proposta de valor permanece sendo a formação de mão de obra especializada na construção de paredes, mas nota-se uma necessidade de desenvolvimento de controles de produção mais adequados, tendo em vista que a quantidade de metros quadrados de paredes de alvenaria a serem construídos aumentará muito e, consequentemente, a equipe de pedreiros alocados em cada obra;

8. Os recursos-chave para a elaboração de sua proposta de valor permanecem sendo pedreiros treinados, mas se faz necessária uma busca por obras de casas térreas com paredes de alvenaria estrutural e de gestores de obra com experiência no novo mercado;

9. Os principais itens da estrutura de custos necessária para suportar a elaboração de sua proposta de valor permanece sendo a remuneração dos recursos humanos envolvidos, deixa de ser a aquisição de materiais pois, nesse mercado, eles são tradicionalmente fornecidos pelas empresas construtoras e os custos com alojamento aumentam, pois a equipe é maior e grande parte das obras situam-se em cidades do interior de São Paulo. 
Dado que as premissas escritas em vermelho correspondem a componentes não familiares à empresa, é possível identificar as diretrizes necessárias para orientar uma nova estratégia de inovação, que deverá, por exemplo:

- Em relação às alterações na proposta de valor: identificar mudanças impostas pela alteração do método construtivo nessa nova proposta de valor, redefini-lo e capacitar a mão de obra para executá-lo;

- Em relação às alterações no segmento de clientes: identificar necessidades do novo segmento de clientes e, caso necessário, fazer adaptações na proposta de valor;

- Em relação às alterações na fonte de receitas: estabelecer novos critérios de medição, que deixaram de ser por metro quadrado de parede e passaram a ser por casa de alvenaria estrutural construída;

- Em relação às alterações nos parceiros-chave: identificar, por meio de experimentação, se haverá ou não a necessidade de se ter parceiros-chave;

- Em relação às alterações nas atividades-chave: elaborar processos de controle de produção que sejam, sempre que possível, semelhantes aos processos de controle de produção que já vem sendo utilizados;

- Em relação às alterações nos recursos-chave: capacitar gestores de obra aos novos processos de controle de produção;

- Em relação às alterações na estrutura de custos: estimar custos com alojamento, analisando sua relevância dentro da nova estrutura de custos. Compará-la financeiramente às novas fontes de receita esperadas.

Assim, quando a estratégia de inovação requer certa descoberta de componentes diferentes do modelo de negócio vigente da empresa, diz-se que os projetos de inovação fazem parte do Horizonte 2.

\subsubsection{Definição de diretrizes para inovações no Horizonte 3}

Neste caso, a diretoria da empresa notou uma oportunidade de atuação no mercado de fabricação e venda de equipamentos metálicos de serralheria, a princípio, como uma forma de reduzir a estrutura de custos do modelo de negócio vigente.

A oportunidade de inovação foi identificada por meio de uma análise financeira, que mostrou que os custos com locação eram tão altos que o investimento em espaço, maquinário e profissionais para fabricação só para fornecimento interno era justificado. 
Assim, esta área de apoio à produção, responsável pela aquisição das matérias-primas, recebimento dos pedidos, fabricação e entrega dos equipamentos foi constituída. Os principais investimentos iniciais relacionavam-se à compra de equipamentos de corte, calandragem e solda de barras e chapas metálicas, a contratação de serralheiros e de um supervisor de produção e a locação de um galpão industrial.

Assim, a serralheria foi constituída e funcionou como área de apoio à produção por cerca de 5 anos, período em que consolidou seus processos administrativos e de produção atendendo exclusivamente às demandas internas por equipamentos metálicos. Com isso, a diretoria, vislumbrando demanda, aproveitando o conhecimento acumulado pelos profissionais e a capacidade instalada do maquinário, decidiu transformá-la em uma empresa, num processo de "derivação" denominado spin-off. Assim, a fabricação de equipamentos metálicos de serralheira deixava de ser uma atividade de apoio à proposta de valor do modelo de negócio vigente, passando a constituir uma nova proposta de valor de um novo modelo de negócio que, na época, era desconhecido.

As premissas adotadas para esse novo modelo de negócio foram representadas, de forma simplificada, pelo Quadro de Modelo de Negócio mostrado na Figura 37. Da mesma forma que o exemplo anterior, as premissas escritas na cor preta correspondem aos componentes do modelo de negócio vigente da empresa que, a princípio, poderiam ser aproveitados no novo modelo de negócio. As escritas em vermelho correspondem a componentes não familiares à empresa, a princípio, necessários ao funcionamento do novo modelo de negócio. 


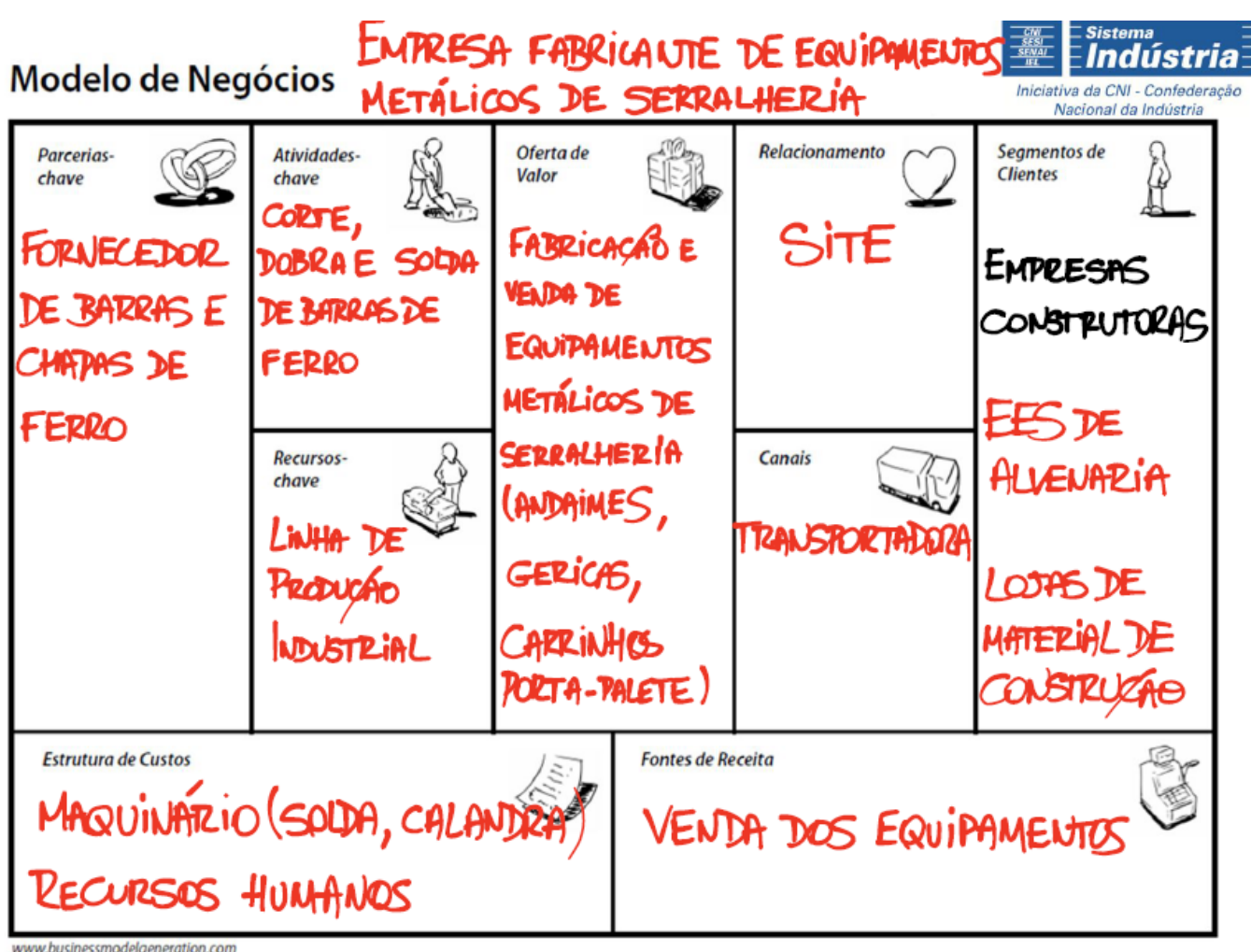

Figura 37 - Quadro de Modelo de Negócio planejado para o ingresso da EEE de alvenaria num mercado completamente novo: o de fabricação de equipamentos metálicos de serralheria (Fonte: o autor).

Comparando-se a Figura 37 ao modelo de negócio vigente da EEE de alvenaria mostrado na Figura 35, é possível, notar que a grande maioria dos componentes necessários ao funcionamento do modelo de negócio não são familiares para a empresa. Não há garantias de que este modelo de negócio irá funcionar e, possivelmente, sua estrutura de custos superará suas fontes de receita até que se encontre uma configuração ideal dos componentes desse modelo de negócio. Por exemplo, ao testar a premissa adotada como fonte de receita, isto é, a venda dos equipamentos metálicos fabricados, pode se chegar à conclusão que os segmentos de clientes representados pelas empresas construtoras e o segmento de clientes representados por EES de alvenaria não têm interesse em adquirir estes equipamentos, mas de locá-los durante o período em que eles serão utilizados em obra.

Desta forma, cada nova possibilidade exigirá um novo teste da premissa adotada no modelo de negócio. O ciclo iterativo composto por experimentação, mensuração de resultados e aprendizado é repetido até que a fonte de receitas do modelo de negócio supere satisfatoriamente sua estrutura de custos. 


\section{Considerações finais}

Com relação ao objetivo principal, que era identificar na literatura um processo adequado para definir diretrizes para formulação de uma estratégia para desenvolvimento de empresas de execução especializada de serviços de obras (EEE) com foco na inovação, esta dissertação identificou um processo de planejamento estratégico baseado na construção de cenários utilizando uma ferramenta de representação visual do esquema de funcionamento de uma empresa, o Quadro de Modelo de Negócio (Business Model Canvas).

A construção, comparação e análise desses cenários contribuem para que as lideranças optem de forma consciente a estratégia mais adequada às características do ambiente e de suas empresas. Apesar do processo ter sido utilizado apenas em uma EEE de alvenaria, acredita-se que ele pode ser adaptado à EEE de qualquer especialidade.

Com relação ao objetivo secundário de identificar características de empresas inovadoras, mostrou-se que são necessárias competências estratégicas, como visão de longo prazo, capacidade de identificar oportunidades, a existência de capacidade inovativa e a formulação de uma estratégia de inovação e competências organizacionais, como uma boa administração, a disposição da liderança para correr riscos, uma estrutura organizacional ambidestra, a disponibilidade de se fazer investimentos e uma cultura organizacional que não seja avessa ao erro.

Com relação ao objetivo secundário de aplicar o método de planejamento estratégico identificado na definição de diretrizes para formulação de uma estratégia de inovação em uma empresa de execução especializada de serviços de obra (EEE) de alvenaria, mostrou-se toda a lógica envolvida na aplicação do processo de planejamento estratégico utilizando o Quadro de Modelo de Negócio (Business Model Canvas), definindo diretrizes a partir três tipos diferentes de estratégia de inovação, uma para o Horizonte 1 (melhoria contínua), uma para o Horizonte 2 (inovação no modelo de negócio) e uma para o Horizonte 3 (modelos de negócio completamente novos).

\subsection{Considerações genéricas sobre a prática da inovação em empresas}

Ao longo desta dissertação, foram abordados conceitos relacionados tanto à prática da administração, quanto à prática da inovação. Estes temas foram escolhidos porque a boa administração é o garante que a empresa sobreviva aos desafios do presente e a prática sistemática da inovação é o que garante que a empresa sobreviva aos desafios do futuro. 
Sempre que possível, a empresa deve buscar inovar nos três Horizontes: procurando aumentar sua eficiência por meio de projetos de melhoria contínua (Horizonte 1), procurando fazer experiências que provoquem alterações nos componentes de seu modelo de negócio vigente, como oferecer sua proposta de valor a um novo segmento de clientes (Horizonte 2) e procurando modelos de negócio completamente diferentes, mas que podem se tornar lucrativos no futuro (Horizonte 3).

Identificar e conhecer profundamente as necessidades e expectativas dos clientes é um dos maiores desafios da inovação. Segundo Frederick (2010), um dos recursos que tem sido utilizado pelas empresas é a participação do cliente no processo de desenvolvimento de novos produtos e serviços como uma forma de reduzir as incertezas e conhecer melhor os desejos latentes dos clientes e aumentar a sintonia do novo produto ou serviço com o mercado.

A adoção da prática sistemática da inovação em uma empresa se traduz em uma vantagem competitiva sustentável perante seus concorrentes e, a longo prazo, garante sua sobrevivência mesmo em ambientes externos de negócio imprevisíveis, modeláveis e altamente competitivos. No entanto, é necessário que as lideranças estabeleçam condições favoráveis à inovação, como definir e alinhar a estratégia de inovação à estratégia e aos objetivos organizacionais, adotar uma estrutura organizacional ambidestra e estimular as interações entre os profissionais que atuam no modelo de negócio vigente e os profissionais de inovação.

Além disso, projetos de inovação necessitam de recursos técnicos e financeiros. Muitas vezes, há a necessidade de acessar um conhecimento específico, indisponível na empresa. Por isso, ter uma rede de relacionamentos com universidades, com empresas de setores diferentes ou com elementos de ligação do sistema nacional de inovação contribui para a superação de obstáculos como esse.

Profissionais capacitados são recursos-chave para as empresas inovadoras. Além disso, o porte, o setor e a maturidade tecnológica da indústria influenciam no processo de inovação das empresas, mas inovar não é exclusividade de grandes empresas ou de empresas de alta tecnologia.

Estimular a comunicação entre profissionais das linhas de vanguarda e retaguarda também é uma fonte importante de ideias e insights. Organizar e divulgar o conhecimento acumulado pelos profissionais, fomentar trocas de experiências e de lições aprendidas são maneiras de estimular o aprendizado organizacional, o que contribui para que os profissionais adotem e incorporem boas práticas às suas rotinas de trabalho. 


\subsection{Considerações específicas sobre a prática de inovação em uma EEE de alvenaria}

Ter uma estratégia é uma necessidade ainda maior nos ambientes imprevisíveis, modeláveis e competitivos como os que operam as EEE. Devido à natureza do trabalho dessas empresas, elas precisam enfrentar, além dos desafios impostos pelo mercado, desafios próprios da indústria da construção civil como a interdependência de tarefas, o processo de acondicionamento e o clima. Estas incertezas se traduzem em risco para uma boa administração de uma EEE.

Em geral, a inovação em EEE se assemelha à natureza das inovações em serviços e, por isso, é importante levar em consideração cada um dos pontos de contato que se tem com os clientes, considerando que suas percepções são determinantes para a avaliação da prestação do serviço (serviço bom é aquele que excede a expectativa do cliente).

As linhas de retaguarda técnica do canteiro (encarregados, mestres de obra, engenheiros, etc.) contribuem para disseminar boas práticas identificadas nas linhas de vanguarda (oficiais diretamente envolvidos na produção, ajudantes, etc.), fomentando uma melhoria contínua de técnicas e métodos construtivos. Além disso, a comunicação informal, quantidade reduzida de níveis hierárquicos e baixos graus de burocratização favorecem a inovação.

Por motivos de confidencialidade, os resultados da adoção de uma estratégia utilizandose os conceitos de Quadro de Modelo de Negócio (Business Model Canvas) e dos Horizontes de Inovação no processo de planejamento estratégico não foram divulgados. No entanto, esperase que a descrição do raciocínio utilizado para a definição das diretrizes para a estratégia de inovação, mostradas no Capítulo 4, sirva de inspiração e guia para líderes que pretendam adotar uma estratégia de desenvolvimento com foco em inovação, mas que não sabem por onde começar.

Pode-se dizer, no entanto, que os fatores que mais contribuem para o sucesso da adoção da inovação como prática sistemática da empresa são: o perfil empreendedor e arrojado da alta direção, a existência de uma estratégia de inovação clara, o compromisso em destinar, anualmente, parte do orçamento exclusivamente para projetos de inovação e uma estrutura organizacional ambidestra, que permitia a coexistência harmoniosa entre os profissionais de inovação e os profissionais que atuam no modelo de negócio vigente graças à mediação dos interesses realizada pelo líder em comum.

Também podem ser apontados como fatores críticos de sucesso o baixo nível de burocratização e a existência de poucos níveis hierárquicos, que contribuíram para simplificar o processo de tomada de decisão e deram agilidade e autonomia aos profissionais envolvidos nos projetos de inovação. Também são importantes, a presença de recursos humanos altamente 
especializados e dispostos a "abraçar" novos projetos graças a uma cultura organizacional que estimula a busca por conhecimento, a comunicação transversal e que não é avessa à experimentação e ao erro, desde que planejada com apoio de profissionais experientes (e que conhecem bem o modelo de negócio vigente) são fundamentais.

\subsection{Limitações e trabalhos futuros}

Quanto ao processo de planejamento estratégico utilizando os conceitos do Quadro de Modelo de Negócio e os Horizontes de Inovação, novas pesquisas podem abordar a utilização do processo em outras EEE, desde que sejam relatadas o tipo de estratégia adotada pela empresa, a existência de uma estratégia de inovação, descrição das linhas de vanguarda e retaguarda presentes em sua estrutura organizacional e se ela pode ser considerada ambidestra, sua capacidade inovativa, quais das 10 dimensões da gestão da inovação ela apresenta e de que forma isso contribui para a prática sistemática da inovação na empresa.

Como este trabalho limitou-se à discussão da inovação em um âmbito estratégico, trabalhos futuros poderiam investigar os processos de inovação no âmbito tático das EEE, respondendo a questões como quais os mecanismos de busca, seleção, implementação e captura de valor da inovação, e descrevendo a evolução, com seus sucessos em fracassos, em cada uma destas etapas ou em uma única etapa. O processo de busca, em geral, é realizado a partir de análises de competências internas e do ambiente externo das empresas em busca de oportunidades para mudança, sejam elas de cunho tecnológico ou não. O processo de seleção trata dos mecanismos de decisão que, baseados na estratégia, escolhe quais dessas oportunidades a empresa deverá explorar. O processo de implementação consiste em traduzir uma ideia de exploração da oportunidade identificada em um produto ou serviço novo para a empresa e lança-lo no mercado. É a etapa mais completa e requer, em geral, a aquisição de novos conhecimentos, a capacidade de executar projetos em condições de imprevisibilidade e a habilidade em divulgar e lançar o novo produto ou serviço em mercados relevantes. Por fim, o processo de captura de valor trata da difusão da inovação no mercado escolhido, dos benefícios extraídos com este lançamento e do aprendizado organizacional adquirido em cada etapa do processo. 


\section{Referências}

ABIKO, A. K. et al. Setor de construção civil: segmento de edificações. Série Estudos Setoriais, Unidade de Tendências e Prospecções do Departamento Nacional do SENAI, Brasília. 2002. Cap. 5. 159 p.

ANTAC (2002). Ciência, tecnologia e inovação e a indústria da construção civil: elementos para a formulação de uma política para o setor. Projeto 7 - Ciência e tecnologia para a inovação na construção. Projeto inovação tecnológica na construção (PIT).

ANTAC (2013). Estratégias para a formulação de política de ciência, tecnologia e inovação para a indústria da construção civil.

BAGHAI, M.; COLEY, S.; WHITE, D. The alchemy of growth: Practical insights for building the enduring enterprise. Da Capo Press, 2000.

BANKVALL, L.; BYGBALLE, L. E.; DUBOIS, A.; JAHRE, M. Interdependence in supply chains and projects in construction. Supply Chain Management: An International Journal, Vol. 15 Iss: 5, pp.385 - 393, 2010.

BARROS, M. M. S. B. de (1996). Metodologia para implantação de tecnologias construtivas racionalizadas na produção de edifícios. 1996. 422 p. Tese (Doutorado) Escola Politécnica, Universidade de São Paulo, São Paulo.

BARROS, M. M. S. B. de; ARAÚJO, L. O. C. de. Desafios para o aumento de produtividade na indústria da construção habitacional. Disponível em: < bibliotecadigital.fgv.br/ojs/index.php/cc/article/view/20699>. Acesso em: 15 Out 2015.

BESSANT, J.; VENABLES, T. Creating wealth from knowledge: meeting the innovation challenge. Cheltenham, Edgard Elgar. 2008

BIRCH, D. Job creation in America. New York Press, Free Press. 1987 
BLANK, S. Lean innovation management: Making corporate innovation work. Jun, 2015. Disponível em: <http://steveblank.com/2015/06/26/lean-innovation-management-makingcorporate-innovation-work/>. Acesso em: 15 Out 2015.

BLANK, S. Innovation outposts and the evolution of corporate R\&D. Nov, 2015. Disponível em: < https://steveblank.com/2015/11/21/at-the-center-of-the-frenzy-innovationoutposts-and-the-evolution-of-corporate-rd/>. Acesso em: 17 Jan 2016.

BURNS, T.; STALKER, G. M. The management of innovation. Londres. Tavistock Public, 1961.

CARDOSO, F. F. (1996). Estratégias empresariais e novas formas de racionalização da produção no setor de edificações no Brasil e na França - Parte 1: $O$ ambiente do setor e as estratégias empresariais. Tese (Doutorado) - Escola Politécnica, Universidade de São Paulo, São Paulo.

CARDOSO, F. F. (1996). Estratégias empresariais e novas formas de racionalização da produção no setor de edificações no Brasil e na França - Parte 2: Do estratégico ao tático - as novas formas de racionalização da produção. Tese (Doutorado) - Escola Politécnica, Universidade de São Paulo, São Paulo.

CARDOSO (2003). Certificações "setoriais" da qualidade e microempresas. O caso das empresas especializadas de construção civil. Livre Docência. Escola Politécnica da Universidade de São Paulo.

CARDOSO (2005). Estudo setorial da construção civil. Capítulo II - A dimensão organizacional da construção civil. Confederação Nacional da Indústria. Serviço Nacional de Aprendizagem Industrial. Série Estudos Setoriais.

CARDOSO, F. F.; OVIEDO HAITO, R. J. J. Diretrizes para a inclusão das empresas especializadas de execução de obras no SiAC/PBQP-H. 2010 (Relatório de Pesquisa).

CASADESUS-MASANELL, R.; RICART, J. E. From strategy to business models and onto tactics. Long Range Planning, v. 43, n. 2, p. 195-215, 2010. 
CBIC (2012). Produtividade da construção civil brasileira. CE no 2418/14. Projeto 054/14 realizado pela Fundação Getúlio Vargas - FGV.

CBIC (2013). Pesquisa anual da indústria da construção (PAIC). Volume 23. Rio de Janeiro. ISSN 0104-34.

CBIC (2015). Sondagem da indústria da construção. Indicadores CNI. ISSN 2317-7322. Ano 6. Número 12. Dezembro de 2015.

CHESBROUGH, H. Business model innovation: it's not just about technology anymore. Strategy \& leadership, v. 35, n. 6, p. 12-17, 2007

CHESBROUGH, H. Business model innovation: opportunities and barriers. Elsevier, v. 43, p. 354-363, 2010.

CHIAVENATO, I. Introdução à teoria geral da administração: uma visão abrangente da moderna administração das organizações. Rio de Janeiro: Elsevier, 2003.

CHRISTENSEN, C. M. O dilema da inovação. São Paulo: Makron Books, 2001.

CLARK, K. B.; WHEELWRIGHT, S. C. Managing new product development-text and cases. Harvard Business School, 1993.

COOPER, R.; EASINGWOOD, C. J.; EDGETT, S.; STOREY, C. "What distinguishes the top performing new products in financial services?" Journal of Product Innovation Management. V. 11, n. 4, p. 281-299, 1994.

CORRÊA, C. (2013). Sonho Grande. $3^{a}$ ed. São Paulo: Editora Sextante, 2013.

De BRENTANI, U. Success and failure in new industrial services. Journal of Product Innovation Management. V. 6, n. 4, p. 239-258, 1989.

DRUCKER, P. F. Sociedade pós-capitalista. São Paulo, Pioneira, 1994. 
DRUCKER, P. F. Tecnologia, gerência e sociedade: as transformações da empresa na sociedade tecnológica. Vozes, 1973.

DUBOIS, A.; GADDE, L. The construction industry as a loosely coupled system:

implications for productivity and innovation. Construction Management and Economics, 20: 7, 621-631. 2002

ENDEAVOR (2015) Scale-ups no Brasil - As empresas que vão tirar o país da crise (e o que você precisa saber sobre elas). Publicação online. Disponível em: < http://info.endeavor.org.br/scale-ups>. Acesso em: 21 Jan. 2016.

EY (2013). Estudo sobre produtividade na construção civil: desafios e tendências no Brasil. Disponível em http://www.ey.com/Publication/vwLUAssets/EY_Estudo_Produtividade_na_Construcao_Civi 1/\$FILE/Estudo_Real_Estate.pdf.

FARAH, M. F. S. Estratégias empresariais e mudanças no processo de trabalho na construção habitacional no Brasil. Encontro Nacional de Tecnologia do Ambiente Construído, v. 2, p. 581-90, 1993.

FREDERICK, B. W. B. Um entendimento ampliado da participação do cliente na inovação em serviços. 2010. 352 p. Tese (Doutorado) - Faculdade de Administração e Economia, Universidade de São Paulo, São Paulo.

GOVINDARAJAN, V; TRIMBLE, C. O desafio da inovação: fundamentos para construir empresas inovadoras em meio a incertezas e complexidades. 1 ed. Rio de Janeiro: Elsevier, 2014.

GRAY, C.; FLANAGAN, R. The changing role of specialist and trade contractors. Ascot: Chartered Institute of Building, 1989.

HENDERSON, B. D. The origin of strategy. Harvard Business Review. Nov-Dec Issue. 1989. 
HUGHES, W. P.; GRAY, C.; MURDOCH, J. Specialist trade contracting - a review. Construction Industry Research and Information Association Special Publication 138. CIRIA, London. 102 p. 1997.

INNOVATION REPORT (2003). Competing in the global economy: the innovation challenge. DTI, UK.

KANTER, R. M. Classe mundial: uma agenda para gerenciar os desafios globais em benefício das empresas e das comunidades. Rio de Janeiro. Editora Campus. 1996. P.32-46.

KATZ, D.; KAHN, R. L. Psicologia social das organizações. 1. ed. São Paulo: Atlas, 1978.

KIM, W. C.; MAUBORGNE, R. A estratégia do oceano azul. Como criar novos mercados e tornar a concorrência irrelevante. Tradução Afonso Celso da Cunha Serra; revisão técnica Consultores Symnetics. 2005.

KUlATUNGA, K. J.; AMARATUNGA, R. D. G.; HEIGH, R. Construction innovation: a literature review on current research. Research Institute of Built and Human Environment, University of Salford, Salford, 2006.

LEMOS C. Inovação na Era do Conhecimento In: Parcerias Estratégicas, nº8, maio, 2000, MCT.

LIN, N. Social capital: theory of social structure and action. Cambridge University. Press, 2001.

LIU, J. B.; OVIEDO HAITO, R. J. J.; CARDOSO, F. F. Classificação do serviço em empresas de execução de serviço de obra. $8^{\circ}$ Simpósio Brasileiro de Gestão e Economia da Construção, 2013.

LORDSLEEM JR, A. C.; BARROS, M. M. S. B. Empresas subempreiteiras: como organizar os processos comercial, de segurança e de produção. Boletim técnico da Escola Politécnica da USP, BT/PCC/335, São Paulo, 2003. 24 p. Disponível em: <http://www.pcc.usp.br/files/text/publications/BT_00335.pdf>. Acesso em: 23 Set. 2016. 
MAGRETTA, J. Why business models matter. 2002. Disponível em: <http://repository.binus.ac.id/2009-2/content/A0154/A015481231.pdf>. Acesso em: 23 Set 2016.

MARTINS, M. G.; BARROS, M. M. S. B (2005). A formação de parcerias como alternativa para impulsionar a inovação na produção de edifícios. Boletim técnico da Escola Politécnica da USP, BT/PCC/391, São Paulo, 2005. 30 p. Disponível em: < http://www.pcc.usp.br/files/text/publications/BT_00391.pdf>. Acesso em: 15 Out. 2016.

MCGRATH, R. D. G. Business models: a discovery driven approach. International Journal of Strategic Management. Long Range Planning. v. 43. Issues 2-3 Apr/Jun 2010. ISSN 00246301.

MELHADO, S. B.; SOUZA, U. E. L. de. Subsídios para avaliação do custo de mão-de-obra na construção civil. São Paulo: EPUSP, 1991.

MINISTÉRIO DE CIÊNCIA E TECNOLOGIA - MCT. Workshop Necessidades de ações de desenvolvimento tecnológico na produção da construção civil e da construção habitacional. Organizado por ABCP - Associação Brasileira de Cimento Portland. 2000

MINTZBERG, H.; AHLSTRAND, B. LAMPEL, J. Safári de estratégia: um roteiro pela sela do planejamento estratégico. Porto Alegre: Bookman Editora, 2000. 177 p.

MINTZBERG, H. The fall and rise of strategic planning. Harvard Business Review. Jan-Feb Issue. 1994.

NAGJI, B.; TUFF, G. Managing your innovation portfolio. Harvard Business Review. May 2012.

ORGANIZAÇÃO PARA A COOPERAÇÃO E DESENVOLVIMENTO ECONÔMICO OCDE. Manual de Frascati. Metodologia proposta para definição da pesquisa e desenvolvimento experimental. Traduzido em 2013 pela F-Iniciativas $\mathrm{P}+\mathrm{D}+\mathrm{I}$ dos originais em inglês e francês: Proposed standard practice for surveys on research and experimental 
development / Méthode type proposée pour les enquetes sur la recherche et le dévelopment expérimental.

ORGANIZAÇÃO PARA A COOPERAÇÃO E DESENVOLVIMENTO ECNONÔMICO OCDE. Manual de Oslo. Proposta e diretrizes para coleta e interpretação de dados sobre inovação tecnológica. Traduzido em 2004 pela FINEP - Financiadora de Estudos e Projetos dos originais em inglês e francês: The measurement of scientific and technological activities proposed guidelines for collect and interpreting technological innovation / La mesure des activités scientifiques et technologiques - Príncipes directeurs proposés pour le recueil et l'interpretation des donnés sur l'innovation technologique.

OHNUMA, D. K.; CARDOSO, F. F. Modelo de processos para a gestão de subempreiteiros: estudo de casos em empresas construtoras de edifícios. Boletim técnico da Escola Politécnica da USP, BT/PCC/441, São Paulo, 2006. 27 p. Disponível em: < http://www.pcc.usp.br/files/text/publications/BT_00441.pdf>. Acesso em: 30 Set 2016.

O'REILLY III, C. A; TUSHMAN, M. L. The ambidextrous organization. Harvard Business Review. Apr 2004.

OSTERWALDER, A.; PIGNEUR, Y. Business model generation - Inovação em modelos de negócio: um manual para visionários, inovadores e revolucionários. Alta Books: 2011. 300 p.

OVANS, A.; What is strategy, again?. Harvard Business Review. 12 May 2015.

OVIEDO HAITO, R. J. J. Caracterização das empresas executoras de serviços de obras baseada nos seus ativos estratégicos. 2010. 173 p. Dissertação (Mestrado) - Escola Politécnica, Universidade de São Paulo. São Paulo.

OVIEDO HAITO, R. J. J. Estratégias para desenvolver empresas de execução especializada de serviços de obra. 2015. 268 p. Tese (Doutorado) - Escola Politécnica, Universidade de São Paulo. São Paulo. 
PACHON, A. G.; JACOB, J.. Necessity of a disruptive change in the construction industry - Analysis of problematic situation. Publicação no CIB*IAARC W119 CIC 2013 Workshop: Advanced Construction and Building Technology for Society. 2013.

PEREIRA, S. R. P.; CARDOSO, F. F. Recomendações de boas práticas na subempreitada de serviços de execução em obras civis. Boletim técnico da Escola Politécnica da USP, BT/PCC/356, São Paulo, 2004. 23 p. Disponível em: < http://www.pcc.usp.br/files/text/publications/BT_00356.pdf>. Acesso em: 22 Out. 2016.

PEREIRA, S. R. P. Os subempreiteiros, a tecnologia construtiva e a gestão dos recursos humanos nos canteiros de obras de edifícios. 2003. 278 p. Dissertação (Mestrado) - Escola Politécnica, Universidade de São Paulo. São Paulo.

PORTER, M. How competitive forces shape strategy. 1979.

PORTER, M. Vantagem Competitiva. Rio de Janeiro. Rio de Janeiro: Editora Campus, v. $79,1989$.

PORTER, M. E. What is Strategy?. Harvard Business Review, November-December: 61-78, 1996.

RAY, G.; BARNEY, J. B.; MUHANNA, W. A. Capabilities, business processes, and competitive advantage: choosing the dependent variable in empirical tests of the resourcebased view. Strategic management journal, v. 25, n. 1, p. 23-37, 2004.

REEVES, M.; LOVE, C.; TILLMANNS, P. Your strategy needs a strategy. Harvard Business Review. Sep Issue. 2012.

RIES, E. A startup enxuta: como os empreendedores atuais utilizam a inovação contínua para criar empresas extremamente bem-sucedidas. São Paulo. Lua de Papel. 2011.

SABBATINI, F. H. Desenvolvimento de métodos, processos e sistemas construtivos: formulação e aplicação de uma metodologia. 1989. 321 p. Tese (Doutorado) - Escola Politécnica, Universidade de São Paulo, São Paulo. 
SAWNHEY, M.; WOLCOTT, R.; ARRONIZ, L. The 12 different ways for companies to innovate. Mit Sloan Management Review, Spring, p. 75-81. 2006.

SCHUMPETER, J.A (1934). The Theory of Economic Development. Harvard University Press, Cambridge, Massachusetts.

SCHUMPETER, J. A. The creative response in economic history. The journal of economic history, v. 7, n. 2, p. 149-159, 1947.

SERRA, S. M. B.; FRANCO, L. S. Diretrizes para gestão de subempreiteiros. Boletim técnico da Escola Politécnica da USP, BT/PCC/295, São Paulo, 2001. 22p. Disponível em: <http://www.pcc.usp.br/files/text/publications/BT_00295.pdf>. Acesso em: 22 Out 2016.

SHAFER, S. M.; SMITH, H. J.; LINDER, J. C. The power of business models. Business horizons, v. 48, n. 3, p. 199-207, 2005.

SLAUGHTER, S. "Rapid" innovation and integration of components: comparison of user and manufacturer innovations through a study of residential construction. 1991. Tese de Doutorado. Massachusetts Institute of Technology.

TEBOUL, J. Service is front stage. Palgrave Macmillan. 2006.

TERRA, J. C. 10 dimensões da gestão da inovação. Elsevier, 2012. 317 p.

THORNHILL, S.; AMIT, R. (2003). Learning from failure: Organizational mortality and the resource-based view. Disponível em $\underline{\text { http://dsppsd. }}$ pwgsc.gc.ca/Collection/Statcan/11F0019MIE/11F0019MIE2003202.pdf

TIDD, J.; BESSANT, J. Gestão da inovação. Porto Alegre: Bookman Editora, 2013. 611 p.

TUSHMAN, M.; SMITH, W.; WOOD, R.; WESTERMAN, G.; O'REILlY, C. (2002). Innovation streams and ambidextrous organizational designs: on building dynamic capabilities. Dezembro, 2002. 
VARGO, S.; LUSCH, R. Why "service"? Journal of the Academic Marketing Science. V.36, 25-38, 2008.

VASCONCELLOS, E.; ANDRADE, V. Gestão estratégica da carteira de projetos: modelo conceitual e aplicação. VI Seminario Latino Americano sobre Gestión Tecnologica y Competitividad, promovido pela Associación Latino Americana de Gestión Tecnologica. Concepción, Chile 20-22 Setembro, 1995.

VASCONCELlOS, E.; TARSO, P. Gestão tecnológica e competitividade - O Caso da Cosipa. XX Simpósio de Gestão da Inovação Tecnológica, 1998.

WOODWARD, J. Management and technology. Londes, Oxford University Press, 1970.

ZOTT, C.; AMIT, R. The fit between product market strategy and business model: implications for firm performance. Strategic management journal, v. 29, n. 1, p. 1-26, 2008. 